Cochrane Database of Systematic Reviews

\title{
Absorbable suture materials for primary repair of episiotomy and second degree tears (Review)
}

Kettle C, Dowswell T, Ismail KMK

Kettle C, Dowswell T, Ismail KMK.

Absorbable suture materials for primary repair of episiotomy and second degree tears.

Cochrane Database of Systematic Reviews 2010, Issue 6. Art. No.: CD000006.

DOI: 10.1002/14651858.CD000006.pub2.

www.cochranelibrary.com 
TABLE OF CONTENTS

HEADER

ABSTRACT

PLAIN LANGUAGE SUMMARY

BACKGROUND

OBJECTIVES

METHODS

RESULTS

DISCUSSION

AUTHORS' CONCLUSIONS

ACKNOWLEDGEMENTS

\section{REFERENCES}

\section{CHARACTERISTICS OF STUDIES}

\section{DATA AND ANALYSES}

Analysis 1.1. Comparison 1 Synthetic sutures versus catgut, Outcome 1 Short-term pain: pain at day 3 or less (women experiencing any pain).

Analysis 1.2. Comparison 1 Synthetic sutures versus catgut, Outcome 2 Short-term pain: pain at day $4-10$.

Analysis 1.3. Comparison 1 Synthetic sutures versus catgut, Outcome 3 Analgesia use - up to day 10.

Analysis 1.4. Comparison 1 Synthetic sutures versus catgut, Outcome 4 Suture dehiscence (wound breakdown).

Analysis 1.5. Comparison 1 Synthetic sutures versus catgut, Outcome 5 Superficial wound dehiscence, wound gaping up to day 10.

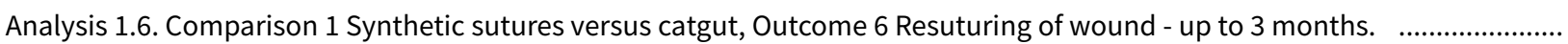
Analysis 1.7. Comparison 1 Synthetic sutures versus catgut, Outcome 7 Removal of suture material - up to 3 months. ............ Analysis 1.8. Comparison 1 Synthetic sutures versus catgut, Outcome 8 Long-term pain - at 3 months postpartum. ................ Analysis 1.9. Comparison 1 Synthetic sutures versus catgut, Outcome 9 Dyspareunia - at 3 months postpartum. .................... Analysis 2.1. Comparison 2 Fast-absorbing synthetic versus standard absorbable synthetic material, Outcome 1 Short-term pain: at 3 days or less.

Analysis 2.2. Comparison 2 Fast-absorbing synthetic versus standard absorbable synthetic material, Outcome 2 Short-term pain: at 10 - 14 days.

Analysis 2.3. Comparison 2 Fast-absorbing synthetic versus standard absorbable synthetic material, Outcome 3 Use of analgesics at 10 days.

Analysis 2.4. Comparison 2 Fast-absorbing synthetic versus standard absorbable synthetic material, Outcome 4 Wound gaping - up to 10 days.

Analysis 2.5. Comparison 2 Fast-absorbing synthetic versus standard absorbable synthetic material, Outcome 5 Resuturing at 3 months postpartum.

Analysis 2.6. Comparison 2 Fast-absorbing synthetic versus standard absorbable synthetic material, Outcome 6 Suture material removed - up to 3 months.

Analysis 2.7. Comparison 2 Fast-absorbing synthetic versus standard absorbable synthetic material, Outcome 7 Long-term pain: pain at 3 months.

Analysis 2.8. Comparison 2 Fast-absorbing synthetic versus standard absorbable synthetic material, Outcome 8 Dyspareunia at 3 months.

Analysis 2.9. Comparison 2 Fast-absorbing synthetic versus standard absorbable synthetic material, Outcome 9 Dyspareunia at 6 - 12 months.

Analysis 2.10. Comparison 2 Fast-absorbing synthetic versus standard absorbable synthetic material, Outcome 10 Maternal satisfaction: satisfied with repair at 3 months.

Analysis 2.11. Comparison 2 Fast-absorbing synthetic versus standard absorbable synthetic material, Outcome 11 Maternal satisfaction: satisfied with repair at 12 months.

Analysis 3.1. Comparison 3 Glycerol impregnated catgut (softgut) versus chromic catgut, Outcome 1 Short-term pain: pain at 3 days or less.

Analysis 3.2. Comparison 3 Glycerol impregnated catgut (softgut) versus chromic catgut, Outcome 2 Short-term pain: pain at 10 - 14 days.

Analysis 3.3. Comparison 3 Glycerol impregnated catgut (softgut) versus chromic catgut, Outcome 3 Analgesia at day 10 . ...... Analysis 3.4. Comparison 3 Glycerol impregnated catgut (softgut) versus chromic catgut, Outcome 4 Wound dehiscence at 10 days. 
Analysis 3.5. Comparison 3 Glycerol impregnated catgut (softgut) versus chromic catgut, Outcome 5 Suture removal by 3 months.

Analysis 3.6. Comparison 3 Glycerol impregnated catgut (softgut) versus chromic catgut, Outcome 6 Long-term pain: pain at 3 months.

Analysis 3.7. Comparison 3 Glycerol impregnated catgut (softgut) versus chromic catgut, Outcome 7 Dyspareunia at 3 months. Analysis 3.8. Comparison 3 Glycerol impregnated catgut (softgut) versus chromic catgut, Outcome 8 Dyspareunia at $6-12$ months.

Analysis 4.1. Comparison 4 Monofilament versus standard polyglycolic sutures, Outcome 1 Short-term pain: mean pain scores at 3 days.

Analysis 4.2. Comparison 4 Monofilament versus standard polyglycolic sutures, Outcome 2 Long-term pain: pain score greater than 2 at $8-12$ weeks.

Analysis 4.3. Comparison 4 Monofilament versus standard polyglycolic sutures, Outcome 3 Long-term pain: mean pain scores at 8 - 12 weeks.

Analysis 4.4. Comparison 4 Monofilament versus standard polyglycolic sutures, Outcome 4 Wound problems at 8 - 12 weeks: women seeking professional help for problem with perineal repair.

APPENDICES

WHAT'S NEW

HISTORY

CONTRIBUTIONS OF AUTHORS

DECLARATIONS OF INTEREST

SOURCES OF SUPPORT

DIFFERENCES BETWEEN PROTOCOL AND REVIEW

INDEX TERMS 
[Intervention Review]

\title{
Absorbable suture materials for primary repair of episiotomy and second degree tears
}

\author{
Christine Kettle ${ }^{1}$, Therese Dowswell ${ }^{2}$, Khaled MK Ismail ${ }^{3}$
}

1Maternity Centre, University Hospital of North Staffordshire, Stoke-on-Trent, UK. ${ }^{2}$ Cochrane Pregnancy and Childbirth Group, School of Reproductive and Developmental Medicine, Division of Perinatal and Reproductive Medicine, The University of Liverpool, Liverpool, UK. 3 Institute of Science and Technology in Medicine, Keele University Medical School, Keele, UK

Contact address: Christine Kettle, Maternity Centre, University Hospital of North Staffordshire, City General Site, Newcastle Road, Stokeon-Trent, Staffordshire, ST46QG, UK. christine.kettle@uhns.nhs.uk, chrisk16@tiscali.co.uk.

Editorial group: Cochrane Pregnancy and Childbirth Group.

Publication status and date: New search for studies and content updated (conclusions changed), published in Issue 6, 2010.

Citation: Kettle C, Dowswell T, Ismail KMK. Absorbable suture materials for primary repair of episiotomy and second degree tears. Cochrane Database of Systematic Reviews 2010, Issue 6. Art. No.: CD000006. DOI: 10.1002/14651858.CD000006.pub2.

Copyright ( 2010 The Cochrane Collaboration. Published by John Wiley \& Sons, Ltd.

\section{A B S T R A C T}

\section{Background}

Approximately $70 \%$ of women will experience perineal trauma following vaginal delivery and will require stitches. This may result in pain, suture removal and superficial dyspareunia.

\section{Objectives}

To assess the effects of different suture materials on short- and long-term morbidity following perineal repair.

\section{Search methods}

We searched the Cochrane Pregnancy and Childbirth Group's Trials Register (February 2010).

\section{Selection criteria}

Randomised trials comparing different suture materials for perineal repair after vaginal delivery.

\section{Data collection and analysis}

Two review authors independently assessed trial quality and extracted data.

\section{Main results}

We included 18 trials with 10,171 women; comparisons included: catgut with standard synthetic (nine trials), rapidly absorbing synthetic (two trials), and glycerol impregnated catgut sutures (two trials); and standard synthetic sutures with rapidly absorbing synthetic (five trials) and monofilament sutures (one trial).

Compared with catgut, standard synthetic sutures were associated with less pain up to three days after delivery (risk ratio (RR) $0.83,95 \%$ confidence interval ( $\mathrm{Cl}) 0.76$ to 0.90 ); and less analgesia up to ten days postpartum ( $\mathrm{RR} 0.71,95 \% \mathrm{Cl} 0.59$ to 0.87 ). More women with catgut sutures required resuturing (15/1201) compared with synthetic sutures (3/1201) (RR 0.25, 95\% $\mathrm{Cl} 0.08$ to 0.74$)$; while more women with standard synthetic sutures required the removal of unabsorbed suture material ( $\mathrm{RR} 1.81,95 \% \mathrm{Cl} 1.46$ to 2.24 ). Comparing standard synthetic with rapidly absorbing sutures, short- and long-term pain were similar; in one trial fewer women with rapidly absorbing sutures reported using analgesics at 10 days (RR $0.57,95 \% \mathrm{Cl} 0.43$ to 0.77 ). More women in the standard synthetic suture group required suture removal compared with those in the rapidly absorbed group ( $\mathrm{RR} 0.24,95 \% \mathrm{Cl} 0.15$ to 0.36 ). There was no evidence of significant differences between groups for long-term pain (three months after delivery) or for dyspareunia at three, or at six to 12 months. When catgut and 
glycerol impregnated catgut were compared, results were similar for most outcomes, although the latter was associated with more shortterm pain. One trial examining monofilament versus standard polyglycolic sutures found no differences for most outcomes.

\section{Authors' conclusions}

Catgut may increase short-term pain compared with synthetic sutures. There were few differences between standard and rapidly absorbing synthetic sutures but more women needed standard sutures removing. For other materials, there was insufficient evidence to draw conclusions. Findings should be interpreted in the context of the related Cochrane review on suturing techniques.

\section{PLAIN LANGUAGE SUMMARY}

\section{Absorbable stitches for repair of episiotomy and tears at childbirth}

Approximately $70 \%$ of women who have a vaginal birth will experience some degree of damage to the perineum, due to a tear or cut (episiotomy), and will need stitches. This damage may result in perineal pain during the two weeks after the birth, and some women experience long-term pain and discomfort during sexual intercourse. The impact of perineal trauma can be distressing for the new mother when she is trying to cope with hormonal changes and the demands of her baby, and it can have a long-term effect on her sexual relationship. Most modern materials that are used to stitch the perineum are gradually absorbed and do not need to be taken out. Sometimes, however, stitches have to be removed by the doctor or midwife. A small number of perineal wounds come open (break down) or have delayed healing, and some of these may need to be re-stitched.

This review includes 18 randomised controlled trials with 10,171 women and looks at catgut and synthetic materials used to stitch the perineum after childbirth. It also includes a more recently produced material which has been specially designed to be absorbed more quickly. The main findings were that women stitched with synthetic materials had less pain in the first three days after delivery and needed fewer drugs to relieve pain in the 10 days after giving birth, compared with women stitched with catgut. There was evidence that synthetic stitches were not always readily absorbed and some women with these stitches needed them to be removed. Women experienced similar short and long-term pain with standard absorbable synthetic materials and more rapidly absorbing stitches. However, in one trial, fewer women with rapidly absorbing stitches reported using pain-relieving drugs during the 10 days after delivery, and there was less need for these stitches to be removed. When catgut and glycerol-impregnated catgut were compared the results were similar, although the latter was associated with more short-term pain. One trial examined monofilament and standard synthetic stitches and there was little difference between the two materials in terms of pain and wound healing. As well as the type of material used, other factors such as the technique used to carry out the stitching (using a continuous thread or a series of separately tied stitches) and the skill of the person carrying out the procedure, may also affect the amount of pain and the way perineal wounds heal. 


\section{B A C K G R O U N D}

Perineal trauma occurs during spontaneous or assisted vaginal delivery, and is usually more extensive after the first vaginal delivery (Sultan 1996). It is defined as any damage to the genitalia during childbirth that occurs spontaneously or is intentionally made by performing a surgical incision (episiotomy). Spontaneous tears are classified as:

First degree: injury to perineal skin only.

Second degree: injury to perineum involving perineal muscles but not involving the anal sphincter.

Third degree: injury to perineum involving the anal sphincter complex:

3a: less than $50 \%$ of the external anal sphincter (EAS) thickness torn;

3b: more than $50 \%$ of EAS thickness torn;

3c: both EAS and internal anal sphincter (IAS) torn.

Fourth degree: injury to perineum involving the anal sphincter complex (EAS and IAS) and anal epithelium (Sultan 1999).

An episiotomy involves the same structures as a second-degree tear.

In the United Kingdom (UK), approximately 1000 women per day will experience perineal repair following vaginal birth (ONS 2001) and millions more worldwide. The impact of perineal trauma can be extremely distressing for a new mother during the early postnatal period when she is trying to cope with hormonal changes, the demands of her baby and pressures imposed as a result of her changing role. For those women who are unfortunate enough to sustain perineal injury, it is important that skilled operators repair the trauma, using the best suturing techniques and suture materials, in order to minimise any associated short- and long-term morbidity.

There is robust evidence that a continuous non-locking suture technique for repair of the vagina, perineal muscles and skin is superior in terms of reducing postpartum pain compared to the more traditional interrupted method whereby a locking stitch is used to repair the vagina and interrupted stitches are inserted to close the perineal muscles and skin (Kettle 2007). The NICE Intrapartum Guidelines (NICE 2007) also report that the two-stage technique of repair (where the vagina and muscle are sutured, but the perineal skin is left opposed but not sutured) is associated with a reduction in pain (Oboro 2003) and superficial dyspareunia (Gordon 1998; Oboro 2003) up to three months postpartum. However, there is an increased risk of perineal wound skin edges 'gaping' in the two-stage repair groups at two days (Gordon 1998; Oboro 2003) and ten days postpartum (Gordon 1998). Despite this evidence, there are still wide variations between individual practitioners and maternity units in terms of techniques and materials used for perineal repair.

\section{Wound healing}

The type of suturing material used for perineal repair may also have an effect on the amount of pain, wound dehiscence (breakdown) and superficial dyspareunia experienced by women following childbirth. The primary function of a suture is to maintain closure of the damaged tissue in order to promote healing by first intention, control bleeding and minimise the risk of infection. Wound edges must be approximated without tension, otherwise the tissue will become devascularised and the healing process will be disrupted (Cuschieri 2000). Perineal trauma which has been carefully sutured generally heals very rapidly by primary intention. This is probably due to the fact that the perineal area immediately after childbirth provides optimal conditions that are necessary for the promotion of quality healing. The most common local factor associated with delayed perineal wound healing and dehiscence is infection, which adversely causes the wound edges to be softened and this may result in sutures 'cutting out' of the tissue with subsequent wound breakdown (Cuschieri 2000).

The ideal suture material should cause minimal tissue reaction and be absorbed once it has served its purpose of holding the tissue in apposition during the healing process (Taylor 1996). Wellaligned perineal wounds heal by primary intention with minimal complications within two weeks of suturing. However, if the stitches remain in the tissues for longer than this period, they act as a foreign body and may excite a significant inflammatory response and impair healing. Once bacteria have colonised along the implanted sutures or knot interstices, it is difficult to eradicate the infection, and this may predispose to abscess formation and wound dehiscence. Local infection of the wound site will prolong the inflammatory phase and cause further tissue damage, which will delay collagen synthesis and epithelialisation (Flanagan 1997). Tissues with good blood supply, that heal rapidly and which are not under mechanical stress can be sutured with absorbable synthetic material. A variety of materials have been used to suture the perineum following childbirth.

\section{Catgut}

Plain catgut is manufactured from collagen derived from the intestines of healthy mammals (sheep and cows) and it is reported to cause an inflammatory response in the tissues due to the fact that it is broken down by proteolytic enzymes and phagocytosis (Irvin 1981). It is a very unstable and unpredictable material in terms of time taken to be absorbed, especially if there is wound infection or malnutrition. Catgut can be treated with chromate salts (Chromic catgut) to prevent it absorbing as much water as plain catgut, which slows down the absorption process and decreases the inflammatory reaction. Glycerol impregnated catgut (Softgut) was introduced with claims that it remains supple and it does not dry out during use when compared with plain and chromic catgut (Davis and Geck Ltd, Gosport). In 2001, following discussion with the Medical Devices Agency, catgut was no longer available to the UK market; however, it is still used in other non-European countries.

\section{Absorbable synthetic suture materials}

The two most common absorbable synthetic suture materials which are used for perineal repair are polyglycolic acid (Dexon ${ }^{\circledast}$ , Davis \& Geck Ltd. UK) and polyglactin 910 (Vicryl ${ }^{\circledR}$, Ethicon Ltd., Edinburgh, UK) which were introduced in 1970 and 1974, respectively. Standard polyglactin 910 sutures $\left(\right.$ Vicryl $^{\oplus}$ ) are prepared from a copolymer of glycolide and lactide in a ratio of $90 / 10$ and the substances are derived from glycolic and lactic acids (Ethicon 1992). The material is braided to improve handling and is coated with a mixture of a copolymer of lactide and glycolide in the ratio of $65 / 35$ and an equal ratio of calcium stearate to reduce 
bacterial adherence and tissue drag (Ethicon 1992; McCaul 2000). During the manufacturing process, the material is dyed a bright violet colour to improve visualisation during surgical procedures (Craig 1975). The material is attached to various sized stainless steel needles and sterilised by ethylene oxide gas. Polyglycolic acid sutures $\left(\right.$ Dexon $\left.^{\oplus}\right)$ are produced from a homopolymer of glycolide and no dye is added so the resulting material is a light tan colour. The polymer is converted into a braided suture material which is very similar in composition to standard polyglactin 910 (McCaul 2000). The suture material is designed to maintain wound support for up to 30 days and to be totally absorbed by 120 days (polyglactin up to 90 days compared to polyglycolic acid up to 120 days), regardless of the gauge of material (Craig 1975). More recently, a new monofilament absorbable synthetic suture material (Biosyn, Tyco Healthcare), which consists of a mixture of glycolide (60\%), dioxanone (14\%), and trimethylene carbonate (26\%) has become available for perineal repair. The manufacturers claim that Biosyn causes minimal tissue reaction, reduces tissue drag and promotes better wound healing. It is designed to give wound support up to 21 days and is totally absorbed from the tissues in 90 to 110 days.

\section{Rapidly absorbed polyglactin 910 suture material}

A new type of polyglactin 910 suture material (Vicryl Rapide) was first released to the German market in 1987, but it was not available in the UK until after the introduction of CE (Conformité Européene) marketing in 1994. The un-dyed synthetic material (Vicryl Rapide) is identical to standard polyglactin 910 (coated Vicryl ${ }^{\oplus}$ ) in terms of chemical composition, but it is exposed to gamma irradiation during the sterilisation process which results in faster absorption. Vicryl Rapide is designed to give wound support up to 14 days and it is totally absorbed by 42 days, as compared to standard Vicryl which is completely absorbed at 90 days.

The aim of this review is to examine the available research studies and to establish if there is any clear scientific evidence that the type of absorbable suture material used for perineal repair following childbirth influences the rate of morbidity experienced by women during the short- and long-term postpartum period.

This systematic review includes 18 randomised clinical trials and represents an update of the Cochrane systematic review undertaken previously (Kettle 1999).

\section{O B J E C T I VES}

To determine the effects of absorbable synthetic (polyglycolic acid, standard polyglactin 910, monofilament glycomer 631and fast-absorbing polyglactin 910) and catgut (plain, chromic and glycerol impregnated) suture materials on the amount of shortand long-term morbidity experienced by women following perineal repair. The evidence collated in this review may assist purchasers, providers and consumers of health care to choose the most appropriate material for perineal repair in terms of both health gain and cost-effectiveness (Howard 1995).

The main outcomes of interest are: short- and long-term pain; amount of analgesia used; rate of superficial dyspareunia; removal of suture material; re-suturing of wound; and wound dehiscence.

\section{METHODS}

\section{Criteria for considering studies for this review}

\section{Types of studies}

We have included all identified, relevant randomised controlled trials (RCTs) and quasi-RCTs which compared absorbable synthetic suture materials (e.g. standard polyglactin 910; fast-absorbing polyglactin 910; polyglycolic acid; monofilament glycomer 631 and catgut (plain, chromic and glyceral impregnated)) in this review.

Where trials were reported in abstracts we planned to include them, provided that there was sufficient information on study methods to allow us to assess eligibility and risk of bias. If there was insufficient information reported, then we attempted to contact trial authors requesting further information before deciding to exclude any study.

\section{Types of participants}

All primiparous and multiparous women who have sustained perineal trauma and require stitching following an instrumental or spontaneous vaginal delivery.

\section{Types of interventions}

All randomised controlled comparisons of absorbable synthetic suture materials (e.g. standard polyglactin 910; fast- absorbing polyglactin 910; polyglycolic acid; monofilament glycomer 631, and catgut (plain, chromic and glycerol impregnated)).

\section{Types of outcome measures}

The main focus is on outcome measures relating to short- and longterm postpartum morbidity.

Primary outcome measures: short-term pain (maternal pain at up to three and at four to 10 days).

Secondary outcome measures: analgesia use; removal of suture material, resuturing; wound dehiscence; long-term pain; dyspareunia.

As part of the update of the review, we have added a previously unspecified outcome: maternal satisfaction with the repair.

For an earlier version of this review, we sought consumer views regarding what outcomes they thought were important from women's local focus groups and the National Childbirth Trust's Research and Information Group.

The main outcomes of interest from the consumers' point of view were the extent of short- and long-term pain, the removal of suture material, infection and the resumption of pain-free intercourse.

\section{Search methods for identification of studies}

\section{Electronic searches}

We searched the Cochrane Pregnancy and Childbirth Group's Trials Register by contacting the Trials Search Co-ordinator (February 2010).

The Cochrane Pregnancy and Childbirth Group's Trials Register is maintained by the Trials Search Co-ordinator and contains trials identified from: 
1. quarterly searches of the Cochrane Central Register of Controlled Trials (CENTRAL);

2. weekly searches of MEDLINE;

3. handsearches of 30 journals and the proceedings of major conferences;

4. weekly current awareness alerts for a further 44 journals plus monthly BioMed Central email alerts.

Details of the search strategies for CENTRAL and MEDLINE, the list of handsearched journals and conference proceedings, and the list of journals reviewed via the current awareness service can be found in the 'Specialized Register' section within the editorial information about the Cochrane Pregnancy and Childbirth Group.

Trials identified through the searching activities described above are each assigned to a review topic (or topics). The Trials Search Coordinator searches the register for each review using the topic list rather than keywords.

We did not apply any language restrictions.

\section{Data collection and analysis}

We have set out the methods used for data analysis and management, assessment of risk of bias, and measurement of treatment effect used in the original version of this review in Appendix 1. We have described the methods used in this update below.

\section{Selection of studies}

Two review authors independently assessed and selected the trials for inclusion in this review. It was not possible to assess the relevance of the trials blinded because we knew the authors' names, institution, journal of publication and results, when we applied the inclusion criteria. We resolved any disagreement on eligibility for inclusion by discussion.

\section{Data extraction and management}

For eligible studies, two review authors extracted data. We resolved discrepancies through discussion or, if required, we consulted a third author. One review author entered data into Review Manager software (RevMan 2008) and a second author checked for accuracy. $C$ Kettle was the lead investigator for one of the included studies and was not involved in the assessment of the trial or the data extraction.

\section{Assessment of risk of bias in included studies}

Two authors independently assessed risk of bias for each study using the criteria outlined in the Cochrane Handbook for Systematic Reviews of Interventions (Higgins 2008). We resolved any disagreement by discussion.

\section{(1) Sequence generation (checking for possible selection bias)}

We have described for each included study the method used to generate the allocation sequence. We assessed the method as:

- adequate (any truly random process, e.g. random number table; computer random number generator);

- inadequate (any non-random process, e.g. odd or even date of birth; hospital or clinic record number); or

- unclear.

\section{(2) Allocation concealment (checking for possible selection bias)}

We have described for each included study the method used to conceal the allocation sequence and assessed whether intervention allocation could have been foreseen in advance of, or during recruitment, or changed after assignment.

We assessed the methods as:

- adequate (e.g. telephone or central randomisation; consecutively numbered sealed opaque envelopes);

- inadequate (open random allocation; unsealed or non-opaque envelopes, alternation; date of birth);

- unclear.

\section{(3) Blinding (checking for possible performance bias)}

We have described for each included study the methods used, if any, to blind study participants and personnel from knowledge of which intervention a participant received. We assessed blinding separately for different outcomes or classes of outcomes, and we have noted where there was partial blinding.

We assessed the methods as:

- adequate, inadequate or unclear for women;

- adequate, inadequate or unclear for clinical staff;

- adequate, inadequate or unclear for outcome assessors.

(4) Incomplete outcome data (checking for possible attrition bias through withdrawals, dropouts, protocol deviations)

We have described for each included study, and for each outcome or class of outcomes, the completeness of data including attrition and exclusions from the analysis. We have noted whether attrition and exclusions were reported, the numbers included in the analysis at each stage (compared with the total randomised participants), reasons for attrition or exclusion where reported, and whether missing data were balanced across groups or were related to outcomes. We assessed methods as:

- adequate;

- inadequate:

- unclear.

\section{(5) Selective reporting bias}

We have described for each included study how we investigated the possibility of selective outcome reporting bias and what we found.

We assessed the methods as:

- adequate (where it is clear that all of the study's pre-specified outcomes and all expected outcomes of interest to the review had been reported);

- inadequate (where not all the study's pre-specified outcomes had been reported; one or more reported primary outcomes were not pre-specified; outcomes of interest were reported incompletely and so could not be used; study failed to include results of a key outcome that would have been expected to have been reported);

- unclear. 


\section{(6) Other sources of bias}

We have noted for each included study any important concerns we had about other possible sources of bias.

We assessed whether each study was free of other problems that could put it at risk of bias:

- yes;

- no;

- unclear.

\section{(7) Overall risk of bias}

We have made explicit judgements about whether studies are at high risk of bias, according to the criteria given in the Handbook (Higgins 2008) and have explored the impact of the level of bias through undertaking sensitivity analyses - see Sensitivity analysis.

\section{Measures of treatment effect}

\section{Dichotomous dato}

For dichotomous data, we present results as summary risk ratio with $95 \%$ confidence intervals.

\section{Continuous dato}

For continuous data, we have used the mean difference if outcomes were measured in the same way between trials. We planned to use the standardised mean difference to combine trials measuring the same outcome, but using different methods.

\section{Unit of analysis issues}

We had planned to include cluster-randomised trials in the analyses along with individually randomised trials, but we identified no such trials.

We did not consider crossover trials would be feasible for this intervention and have not included such trials.

\section{Dealing with missing data}

For included studies, we have noted levels of attrition in the Characteristics of included studies tables. We have explored the impact of including studies with high levels of missing data in the overall assessment of treatment effect by using sensitivity analysis.

For all outcomes we have carried out analyses, as far as possible, on an intention-to-treat basis, i.e. we attempted to include all participants randomised to each group in the analyses. The denominator for each outcome in each trial is the number randomised minus any participants whose outcomes are known to be missing.

\section{Assessment of heterogeneity}

We examined the forest plots for the analyses visually to assess any obvious heterogeneity in terms of the size or direction of treatment effect between studies. We used the $\mathrm{I}^{2}$ and $\mathrm{T}^{2}$ statistics and the $\mathrm{P}$ value of the $\mathrm{Chi}^{2}$ test for heterogeneity to quantify heterogeneity among the trials in each analysis. For those outcomes where we have identified moderate or high unexplained heterogeneity $\left(\mathrm{I}^{2}\right.$ greater than $40 \%$ ), we have used a random-effects model and have given the values of $\mathrm{I}^{2}, \mathrm{P}$, and $\mathrm{T}^{2}$ with its $95 \%$ prediction interval, to give a sense of the level of heterogeneity. The prediction interval estimates the possible treatment effect in a future study, and if it includes the null value of one it is possible that the direction of the treatment effect in a single study may not be the same as that from the meta-analysis. We would advise that all findings where there are high levels of heterogeneity should be interpreted cautiously.

\section{Data synthesis}

We carried out statistical analysis using the Review Manager software (RevMan 2008). We have used fixed-effect meta-analysis for combining data where trials examined the same intervention, and the trials' populations and methods were judged sufficiently similar.

As noted above, if we identified substantial heterogeneity in a fixedeffect meta-analysis we used a random-effects model.

\section{Sensitivity analysis}

We carried out a sensitivity analysis excluding those studies with poor allocation concealment or high levels of attrition to see whether this had any impact on the results.

\section{RES U L T S}

\section{Description of studies}

\section{Results of the search}

In the original review there were eight included trials (Banninger 1978; Beard 1974; Livingstone 1974; Mackrodt 1998; Mahomed 1989; Olah 1990; Roberts 1983; Rogers 1974) and three excluded (Ketcham 1994; Tompkins 1972; Wikoff 1992). Additional information was required for one study that was awaiting assessment in the original review (Hemsley 1997) and despite several attempts, we have been unable to contact the author, and so we have now excluded it. For this update, the search strategy identified a further 16 reports, representing 13 studies, for possible inclusion. We have included 10 new studies (Dencker 2006; Gemynthe 1996; Greenberg 2004; Kettle 2002; Leroux 2006; McElhinney 2000; Nikolov 2006; Saint 1993; Spencer 1986; Upton 2002), and excluded another three studies (Gaasemyr 1977; Marques 2001; Uslu 1992).

\section{Included studies}

Six of the trials included in this review compared polyglycolic acid (Dexon) versus chromic catgut and the same material was used throughout for all layers of the perineal repair (vagina, muscle and skin) (Banninger 1978; Beard 1974; Mahomed 1989; Olah 1990; Roberts 1983; Rogers 1974). One trial (Mackrodt 1998) compared polyglactin (Standard Vicryl) to chromic catgut, one plain catgut with Dexon (Livingstone 1974). Two trials compared fast-absorbing polyglactin (Vicryl Rapide) with chromic catgut (Greenberg 2004; Leroux 2006).

Five trials compared standard absorbable polyglycolic or polyglactin sutures with fast-absorbing synthetic sutures (Vicryl Rapide) (Gemynthe 1996; Kettle 2002; Leroux 2006; McElhinney 2000; Nikolov 2006).

Two trials examined catgut compared with glycerol impregnated catgut (Softgut) (Saint 1993; Spencer 1986); and one trial looked at an absorbable monofilament synthetic material (Biosyn) versus polyglycolic acid (Dencker 2006). 
One trial (Leroux 2006) included three arms and compared catgut, fast-absorbing and standard synthetic sutures; we have included this in more than one comparison.

Most of the trials included women undergoing episiotomy along with those sustaining second-degree tears, although in five trials women with episiotomy only were included (Banninger 1978; Beard 1974; Livingstone 1974; Nikolov 2006; Roberts 1983), and in one trial only women having an episiotomy following instrumental deliveries were included (Olah 1990).

There was considerable variation in the trials between gauge of suture material and size of needle (see Characteristics of included studies tables for details). One of the trials (Banninger 1978) compared chromic catgut gauge 0 (a heavier gauge material) to Dexon 2/0 (a much finer gauge material) in order to match tensile strength. It is possible that the heavier gauge catgut material may have contributed to the degree of pain experienced by the women in this trial group.

The same suturing technique was used for both groups in each of the included trials; however, there were differences between trials in techniques for closure of the vagina, perineal muscles and skin (see Characteristics of included studies tables). In three trials the perineal skin was closed with interrupted sutures (Banninger 1978; Livingstone 1974; Roberts 1983), whilst five trials used continuous subcuticular or subcutaneous closure (Beard 1974; Leroux 2006; McElhinney 2000; Olah 1990; Upton 2002). Four of the trials used both continuous subcuticular and interrupted techniques for perineal skin closure (Dencker 2006; Mahomed 1989; Saint 1993; Spencer 1986). and in three of the trials this was based on the operators' preference (Dencker 2006; Saint 1993; Spencer 1986). In one trial operators used the continuous subcuticular technique for skin closure except for one operator that used the interrupted method (Greenberg 2004). The women participating in the Ipswich Childbirth Study (Mackrodt 1998) were randomly assigned to either a two-stage (skin left un-sutured) or a threestage (skin sutured) technique of perineal repair (50/50). In the group that was assigned to have the perineal skin sutured, it was left to the midwives' discretion and skill as to the method used. In fact, $72 \%$ had transcutaneous interrupted sutures and $26 \%$ had continuous subcutaneous sutures. The trial carried out by Kettle 2002 used a factorial $2 \times 2$ design, and women were assigned to either perineal skin closure using a continuous subcutaneous or interrupted technique (50/50). In three trials (Gemynthe 1996; Nikolov 2006; Rogers 1974), the suturing techniques were not described.

\section{Excluded studies}

We excluded seven studies; four of these because there was insufficient information in trial reports on methods or results so as to allow assessment of risk of bias, or to allow us to incorporate trial results into the review (Ketcham 1994; Marques 2001; Tompkins 1972; Wikoff 1992). One report was a trial registration, no results were reported, and it was not clear whether the study had ever been completed (Hemsley 1997). In one study the intervention examined was a non-absorbable suture material, which is rarely used in perineal repair nowadays (Gaasemyr 1977). Finally, Uslu 1992 compared mixed materials and different techniques in different arms of the trial, so that the effects of particular materials could not be discerned.

\section{Risk of bias in included studies}

The methodological quality of the included trials was mixed and we have carried out a sensitivity analysis to examine the impact of excluding trials at high risk of bias on account of inadequate allocation concealment and high levels of attrition (greater than $20 \%)$.

\section{Allocation}

Most of the included studies used adequate methods of sequence generation and allocation concealment. Computerised random number generators or random number tables were used in five studies and these studies also used sealed, opaque, sequentially numbered envelopes to conceal group assignment (Dencker 2006; Greenberg 2004; Kettle 2002; Mahomed 1989; Upton 2002). Mackrodt 1998 used a balanced block design with sealed opaque sequentially numbered envelopes for concealment of treatment allocation. In the trials by Spencer 1986; McElhinney 2000; Gemynthe 1996 Rogers 1974 and Leroux 2006, envelopes were also used to conceal allocation, although it was not explicitly stated that the envelopes were opaque, sealed and numbered. Two trials used quasi-random allocation (Banninger 1978; Olah 1990); one trial used 'lottery cards' (Livingstone 1974) and four trials did not describe their method of sequence generation or allocation concealment (Beard 1974; Nikolov 2006; Roberts 1983; Saint 1993).

\section{Blinding}

Kettle 2002 and Leroux 2006 (both of which compared standard absorbable with fast-absorbing synthetic materials) reported that both suture materials appeared very similar and packaging was identical. In the Kettle 2002 trial, suture materials were dyed the same colour in order to achieve convincing blinding of clinical staff and outcome assessors. In several of the included trials (Beard 1974; Dencker 2006; Livingstone 1974; Spencer 1986) it was claimed that outcome assessment was 'blinded' due to the different suturing materials appearing the same by day three, but from our own experience, this is not convincing.The Mahomed 1989 trial acknowledged that fully 'blind' outcome assessment was not possible due to obvious differences in suture materials and techniques. Mackrodt 1998 reports that a research midwife 'blinded' to the treatment allocation undertook a 'face-to-face' interview at 24 to 48 hours and 10 days followed by assessment of the woman's perineum. It is possible that an element of observer bias was introduced due to the obvious differences in methods of perineal repair.The remaining trials did not state if any attempt was made to 'blind' outcome assessment.

\section{Incomplete outcome data}

Most of the trials had relatively low attrition for outcomes assessed within the first three days after delivery (less than $10 \%$ women lost to follow up or missing outcome data). For longer-term follow up (outcomes at 10 to 14 days and at 12 weeks), some trials achieved less than 10\% loss to follow up (Kettle 2002; Rogers 1974; Mackrodt 1998); however, other trials had considerable levels of attrition. In Gemynthe 1996, McElhinney 2000, Dencker 2006 and Leroux 2006, attrition at 12 weeks was greater than 20\%; and in Banninger 1978 and Greenberg 2004 by this stage, more than half of the sample randomised had been lost to follow up. We have provided information on attrition for all of the included studies in the Characteristics of included studies tables. We would advise caution in the interpretation of results from those studies where 
there is high attrition, as those women available to follow up may not be representative of the sample randomised.

\section{Other potential sources of bias}

Where information was provided on sample characteristics, in most of the included studies the women in intervention and control groups appeared similar, although in the study by Upton 2002 there was some baseline imbalance in the parity of women in the two groups; the authors carried out further analysis to attempt to adjust for this difference. In Leroux 2006, the study was discontinued as catgut (one of the comparators) was withdrawn from the study hospital drugs list part way through the planned recruitment period. In Greenberg 2004, women were randomised before delivery and of the 1361 randomised, only 908 (67\%) required perineal repair, were eligible for the trial's outcomes, and were included in the analysis.

\section{Effects of interventions}

For all outcomes there may be an interaction between the type of material used (the focus of this review) the suturing technique, i.e. interrupted versus continuous stitches (the subject of a related Cochrane review (Kettle 2007)); we return to this issue in the discussion.

There was variation in when and how outcomes were measured in different studies; in particular there was variation in the terminologies used to describe wound outcomes. For the purpose of this review we have reported on these outcomes in two categories: (1) wound gaping and partial skin dehiscence, which tends to be a reflection of the repair technique (two-stage versus three-stage perineal wound closure) and type of skin suture placement (interrupted versus continuous subcutaneous or subcuticular) and, (2) wound dehiscence or breakdown.

\section{Absorbable synthetic sutures versus catgut: 11 trials with 5072 women}

\section{Primary outcomes}

All 11 trials included data on pain at or before three days after delivery.

In trials comparing standard absorbable synthetic sutures with catgut, fewer women with synthetic sutures experienced pain (risk ratio (RR) $0.83,95 \%$ confidence interval $(\mathrm{Cl}) 0.76$ to 0.90 , nine trials, 4017 women) (Analysis 1.1). However, there is evidence of large heterogeneity in the treatment effect across studies (heterogeneity: $\mathrm{I}^{2}=57 \%, \mathrm{~T}^{2}=0.02$ (95\% prediction interval 0.59 to 1.18 ), $\mathrm{P}=0.02$ ). Three of these trials collected data on pain at four to 10 days following delivery. Again, results favoured women with synthetic sutures (RR $0.78,95 \% \mathrm{Cl} 0.67$ to 0.90 , three trials, 2044 women) (Analysis 1.2).

In a single trial (Greenberg 2004) comparing fast-absorbing synthetic sutures and catgut there was no evidence of a difference between groups at either three days ( $\mathrm{RR} 1.02,95 \% \mathrm{Cl} 0.98$ to 1.06 ) or at four to 10 days after delivery (RR $1.05,95 \% \mathrm{Cl} 0.94$ to 1.18 ).

Data from one trial (Leroux 2006) were not reported in a way in which we were able to incorporate them into the meta-analyses; authors reported no significant differences between materials (catgut, standard and fast-absorbing synthetic sutures) for median pain scores at 36 to 48 hours.

\section{Seconday outcomes}

In those trials examining analgesia use up to 10 days, women with synthetic sutures had less analgesia than those with catgut sutures (RR $0.71,95 \% \mathrm{Cl} 0.59$ to 0.87 , five trials, 2820 women) (Analysis 1.3), although there was high heterogeneity for this outcome (heterogeneity: $\mathrm{I}^{2}=48 \%, \mathrm{~T}^{2}=0.05$ (95\% prediction interval 0.33 to 1.55), $\mathrm{P}=0.10$ ). In the single trial looking at fast-absorbing synthetic sutures versus catgut (Greenberg 2004), the difference in analgesia use between groups was not statistically significant (RR 0.96, 95\% $\mathrm{Cl} 0.90$ to 1.01$)$.

Wound breakdown was measured in five trials (Banninger 1978; Beard 1974; Greenberg 2004; Livingstone 1974; Mackrodt 1998) although there was variability in what was reported and when wound assessment took place. (We have provided details in the Characteristics of included studies tables of how wound breakdown was defined and when it was assessed.) Two of the trials appeared to assess more serious wound dehiscence with complete breakdown of the repair (Greenberg 2004; Mackrodt 1998); relatively few women experienced this outcome and there was no significant evidence of any difference between groups (Analysis 1.4). Four studies (Banninger 1978; Beard 1974; Livingstone 1974; Mackrodt 1998) assessed what we judged, to be more superficial partial skin dehiscence, for example, wound (skin edges) "gaping"; results favoured synthetic sutures compared with catgut (RR $0.58,95 \% \mathrm{Cl} 0.36$ to 0.94 , four trials, 2219 women) (Analysis 1.5). While $15.7 \%$ of those with synthetic sutures had wound gaping, this applied to $25.5 \%$ of those with catgut sutures (unweighted percentages). However, there was high heterogeneity for this outcome (heterogeneity: $I^{2}=65 \%, \mathrm{~T}^{2}=0.14$ (95\% prediction interval 0.08 to 3.97$), P=0.04$ ) and results should be interpreted with caution. More women with catgut sutures required perineal resuturing (15/1201) compared with those with synthetic sutures in the trials examining this outcome (3/1201) (RR $0.25,95 \% \mathrm{Cl} 0.08$ to 0.74 , four trials, 1402 women) (Analysis 1.6). On the other hand, more women with standard synthetic sutures required the removal of unabsorbed suture material ( $\mathrm{RR} 1.81,95 \% \mathrm{Cl} 1.46$ to 2.24 , three trials, 2520 women) (Analysis 1.7).

There was no evidence of any difference in suture materials for pain at eight to 12 weeks postpartum (Analysis 1.8) although approximately $10 \%$ of women with either catgut or standard absorbable sutures continued to experience perineal pain three months after the birth of their babies. (Approximately a quarter of the women in the study by Greenberg 2004 reported longterm perineal pain, although these results should be viewed with caution in view of the high levels of attrition in this trial.) Similarly, while there was no evidence of any significant difference between groups for dyspareunia at three months, more than $15 \%$ of women (irrespective of suture material) reported painful sexual intercourse three months after delivery (Analysis 1.9).

\section{Sensitivity analysis}

Several of the included studies used quasi-randomisation or the method of allocation concealment was unclear (Banninger 1978; Beard 1974; Livingstone 1974; Olah 1990). We temporarily removed these studies from the analysis to examine the impact on results. For longer-term outcomes (pain and superficial dyspareunia at three, six or 12 months), several studies had high levels of attrition (greater than 20\%) (Banninger 1978; Greenberg 2004). Again, 
for long-term outcomes affected by high levels of attrition, we examined the impact of removing studies from the analysis.

The sensitivity analysis did not indicate that removing studies with higher risk of bias had any important impact on overall findings.

\section{Fast absorbing versus standard synthetic sutures: five trials with 2349 women}

\section{Primary outcomes}

There was no significant evidence of any difference between groups sutured with standard versus rapidly absorbing sutures in the numbers of women experiencing perineal pain at up to three days after delivery (data were pooled from three trials with 1968 women, RR 1.01, 95\% Cl 0.92 to 1.10 ) (Analysis 2.1). Similarly, differences between groups for perineal pain at 10 to 14 days were not statistically significant (RR $0.92,95 \% \mathrm{Cl} 0.81$ to 1.03 , two trials, 1847 women) (Analysis 2.2).

\section{Secondary outcomes}

Use of analgesia for perineal pain was reported in one trial (Kettle 2002), and fewer women with rapidly absorbing sutures were using analgesics at 10 days post delivery (RR $0.57,95 \% \mathrm{Cl} 0.43$ to 0.77 ) (Analysis 2.3).

Two trials (Kettle 2002; Nikolov 2006) provided data on partial skin dehiscence or gaping where this is sometimes considered to be an expected outcome and is a reflection of the repair technique used and suture placement (e.g. subcutaneous or subcuticular sutures). Women sutured with fast-absorbing synthetic sutures were more likely to have wound skin edges gaping at up to 10 days, compared with those with standard synthetic sutures $(6 \%$ versus $3.6 \%$, unweighted percentages) (RR $1.67,95 \% \mathrm{Cl} 1.07$ to 2.60 , two trials, 1659 women) (Analysis 2.4).

There were no data reported in these trials for serious wound breakdown, although one trial (Kettle 2002) collected information on wound resuturing and there was no significant difference between groups; three women sutured with fast-absorbing material required resuturing compared with one woman with standard synthetic sutures (Analysis 2.5). More women with standard sutures required the removal of suture material compared with those with rapidly absorbing stitches (RR $0.24,95 \% \mathrm{Cl} 0.15$ to 0.36 , two trials, 1847 women) (Analysis 2.6).

There was no evidence of any significant differences between groups for long-term pain (at three months after delivery) or for dyspareunia at three, or at six to 12 months (Analysis 2.7; Analysis 2.8; Analysis 2.9). However, dyspareunia at three months was experienced by more than $20 \%$ of women regardless of suture material, and in one of the trials where women were followed up for a year after the birth of their babies, more than $10 \%$ were still experiencing pain during sexual intercourse (Kettle 2002).

\section{Non-prespecified outcomes}

One study (Kettle 2002) collected information on women's satisfaction with repair of their perineum. Slightly more women in the rapidly absorbed suture group compared with the standard Vicryl group expressed satisfaction with the repair at both three months $(81.4 \%$ versus $77.8 \%)$, and at 12 months postpartum $(83.1 \%$ versus $81.8 \%$ ) but differences between groups were not significant (Analysis 2.10; Analysis 2.11).

\section{Sensitivity analysis}

For longer-term outcomes (pain and superficial dyspareunia at three, six or 12 months) three studies had high levels of attrition (greater than 20\%) (Gemynthe 1996; Leroux 2006; McElhinney 2000) and for outcomes affected by high levels of attrition, we examined the impact of temporarily removing studies from the analysis. The sensitivity analysis did not indicate that removing studies with higher risk of bias due to attrition had any important impact on findings.

\section{Standard catgut versus glycerol impregnated catgut: two trials with 1737 women}

\section{Primary outcomes}

Pain at three days after delivery was examined in one trial (Saint 1993) and there was no evidence of any difference between groups sutured with either chromic catgut or glycerol impregnated catgut (Softgut) (Analysis 3.1). At 10 to 14 days pain was measured in two trials (Saint 1993; Spencer 1986) and Softgut was associated with more women experiencing pain, but the difference between groups was not significant (RR 1.15, 95\% Cl 0.85 to 1.56) (Analysis 3.2).

\section{Secondary outcomes}

There was no strong evidence of any difference between groups in women's use of analgesia up to 10 days after delivery in the one trial (Spencer 1986) that reported this outcome (RR 1.91, 95\% Cl 0.78 to 4.68). There was no significant difference in the number of women with wound dehiscence at 10 days (Analysis 3.4). More women with standard catgut required the removal of suture material by three months (RR $0.42,95 \% \mathrm{Cl} 0.27$ to 0.67 , one trial, 655 women). There was no information reported on the number of women requiring resuturing.

There was no strong evidence of differences between groups for longer-term pain or dyspareunia at three or at six to 12 months (Analysis 3.6; Analysis 3.7; Analysis 3.8); overall, approximately 25\% of women continued to experience dyspareunia three months after the birth of their babies.

\section{Sensitivity analysis}

In one of the studies included in this comparison the method used for allocation concealment was unclear (Saint 1993); for those outcomes where more than one study contributed data, temporarily removing this study from the analysis had no important impact on results.

\section{Absorbable monofilament sutures versus standard polyglycolic: one trial with 1139 women}

\section{Primary outcomes}

Only one trial contributed data to this outcome (Dencker 2006). There was no evidence of any differences in mean pain scores for women repaired with synthetic monofilament sutures or polyglycolic acid sutures at one to three days after delivery (mean difference $0.13,95 \% \mathrm{Cl}-0.12$ to 0.32 ).

\section{Secondary outcomes}

There was no strong evidence of any difference between group for pain at eight to 12 weeks (Analysis 4.3). Women sutured with monofilament material were more likely to report "wound 
problems" at eight to 12 weeks ( $\mathrm{RR} 2.42,95 \% \mathrm{Cl} 1.43$ to 4.11 ). One woman in each group had wound breakdown requiring resuturing.

\section{Sensitivity analysis}

We did not carry out formal sensitivity analysis for this comparison as only one study contributed data; however, this study had high levels of attrition (> 30\%) for outcomes at eight to 12 weeks, and data for longer term outcomes are at high risk of bias and should be interpreted with caution.

\section{DISCUSSION}

\section{Summary of main results}

The meta-analysis of the data from the included trials comparing catgut and synthetic materials provides significant evidence that synthetic absorbable suture material (polyglactin 910 and polyglycolic acid) is associated with less short-term pain, a reduction in the use of analgesia and less wound dehiscence, but with the need for more suture removal. However, the long-term effects of differences between these materials are less clear.

When standard (polyglactin 910/polyglycolic acid) and rapidly absorbed synthetic sutures were compared, there was no significant evidence of difference in short-term pain. However, one trial (Kettle 2002) suggested that analgesia use up to 10 days postpartum was reduced with rapidly absorbed suture material. There were few cases of serious wound dehiscence, although superficial partial skin dehiscence (skin edges gaping) was slightly increased with rapidly absorbing $(6 \%, 50 / 829)$ as compared with standard sutures $(3.6 \%, 30 / 830)$. This finding should be interpreted in the context of the whole review, as it was considerably less than the rates of superficial perineal wound dehiscence (gaping) at 10 days postpartum that was reported in the trials comparing standard synthetic material $(15.7 \%, 174 / 1111)$ to catgut $(25.5 \%$, 283/1108) (unweighted percentages). Moreover, there were more women with standard synthetic material requiring suture removal compared with those sutured with rapidly absorbing material. There was little evidence of differences between materials in terms of longer-term outcomes.

There were a limited number of other research trials included in this review that compared other types of absorbable suture materials; however there was little evidence of differences between groups.

\section{Overall completeness and applicability of evidence}

The studies included in the review were carried out over a long period of time (almost 40 years) and in contexts where local custom and practice differed considerably. During this time catgut has been largely superseded in developed countries by absorbable synthetic suture materials for perineal repair.

An important factor to consider when interpreting results is the clinical heterogeneity among the included trials; trials differed considerably in terms of suturing technique used, the calibre of material, size of needle, skill of operators, duration of follow up and outcomes assessed. Therefore, findings must be viewed in the context of the variation between trials. In addition, the extent of perineal trauma, the type of delivery (spontaneous vaginal versus instrumental), the type of episiotomy (medio-lateral versus median), and the performance of an episiotomy versus a tear, may all influence the rate of postpartum perineal pain and dyspareunia, and these must be taken into account when assessing the evidence (Glazener 1995; Graham 1997; Sleep 1984; Thacker 1983; Woolley 1995a; Woolley 1995b). It was not possible to make direct comparisons between the different absorbable suture materials and the different techniques used for perineal repair due to limited availability of information, and therefore, cross reference should be made to the related Cochrane review (Kettle 2007). This related review assessed the effects of continuous versus interrupted absorbable sutures for repair of episiotomy and second-degree perineal tears following childbirth, and found continuous suturing techniques compared with interrupted methods, are associated with less short-term pain.

In some of the included trials, operators were asked to use materials and techniques with which they were unfamiliar. It is possible that, even if the best suture materials and techniques are used, if the operator is relatively unskilled the outcome may be affected. In the Mahomed 1989 trial, midwives carried out only $25 \%$ of the subcuticular and $34 \%$ of interrupted repairs. The reason why so few midwives carried out this procedure was that repair of perineal trauma was a relatively new extension of their role. Mackrodt and colleagues (Gordon 1998) reported that participating midwives were encouraged to use a subcuticular technique for perineal skin closure for women allocated to the three-stage method of repair (skin sutured), however, $72 \%$ of women allocated to this suturing method had interrupted transcutaneous stitches and $12 \%$ of women allocated to the two-stage technique had skin sutures inserted. Consideration must be given to the validity of these findings due to the non-compliance with allocated methods and the differing techniques used between groups, which make the interpretation of the data very difficult. The diversity in the skills and preferences of operators may have contributed to the disparity of results presented in the meta-analysis of data.

\section{Quality of the evidence}

There were differences between the studies included in the review in research methodologies including those related to treatment allocation, concealment, blinding and attrition levels (see Characteristics of included studies tables). Overall, the quality of the studies was mixed, although sensitivity analysis (excluding studies at high risk of bias on account of inadequate allocation concealment or high attrition) suggests that the inclusion of studies with high risk of bias did not affect the general direction of findings, or the size of the treatment effect.

The lack of blinding in most of these studies may be a problem in terms of the overall quality of the evidence. Only two of the included studies provided details of efforts to blind women, clinical staff and outcome assessors to group allocation (Kettle 2002; Leroux 2006). Another possible confounding factor may be the way outcome data were obtained, including the way questions were asked (face-to-face or self-completed questionnaires) and how these outcomes were defined (particularly pain). Additionally, the assessment of perineal healing may have been affected by lack of blinding, in that the outcome assessors may have had preferences (acknowledged or not) for particular types of suturing materials.

For some of the results described in the review (particularly those for pain outcomes), there was evidence of high levels of statistical heterogeneity. Some of this heterogeneity may have occurred as a result of the clinical heterogeneity alluded to above; for example, women may not have been asked about pain in the same way 
in different trials. For several outcomes, results seemed to favour a particular suture material; however, where prediction intervals (estimating the possible range of treatment effects in any future study) were very broad, and included the null value of one, results from meta-analysis should be interpreted very cautiously. Thus, although meta-analysis may suggest a treatment effect in favour of a particular suture material, due to heterogeneity we cannot rule out the possibility that the effect would be the same in a single study. Further research is needed to explain the causes of such between study heterogeneity.

\section{Potential biases in the review process}

We attempted to reduce bias in the reviewing process wherever possible. Two review authors independently assessed the risk of bias and the findings of the included studies. However, it is very difficult to rule out observer bias; for example, assessing risk of bias is a matter of judgement rather than an exact science. We accept that the interpretation of the findings of the review are likely to be affected by subjective factors.

\section{Agreements and disagreements with other studies or reviews}

The findings of this review are in agreement with recommendations made by the NICE Intrapartum Guideline (NICE 2007), RCOG Greentop Clinical Guidelines (RCOG 2007) and Clinical Evidence (Clinical Evidence 2008).

\section{AUTHORS' CONCLUSIONS}

\section{Implications for practice}

This review provides evidence that perineal repair with catgut may increase short-term pain and wound breakdown compared to absorbable synthetic sutures. There were few differences between standard polyglactin 910 and rapidly absorbed synthetic sutures, however, fewer women in the rapidly absorbed suture material group needed sutures removing up to three months postpartum. This is an important finding, as women report that having perineal sutures removed is an extremely unpleasant procedure. Another factor to consider is that if sutures remain in the tissues for longer than is required, they may excite a significant inflammatory response and predispose infection, abscess formation and wound dehiscence (Flanagan 1997), which could impact on expenditure in health care systems .

\section{Implications for research}

We know that the continuous suturing technique for repair of all layers (vagina, perineal muscles and skin) is associated with a significant reduction in pain when compared to the more traditional interrupted method (Kettle 2007). However, what is less clear is the interaction between suture material and suturing technique. It is interesting to note that Olah 1990 compared chromic catgut to polyglycolic acid suture material using a continuous suturing technique and reported no differences in pain between intervention groups. He considered it was the method of repair that was important, and that the type of absorbable suture material used was irrelevant in terms of reducing perineal discomfort. Similarly, Fleming 1990 used chromic catgut and her colleague used polyglactin 910 suture material when performing the loose continuous technique of repair, and she also reported no difference in outcome. Therefore, it may be appropriate to compare standard polyglactin 910 with the more rapidly absorbed suture material in a robust clinical trial, using the continuous suturing technique, in an attempt to obtain the definitive answer as to what is the best absorbable suture material for repair of episiotomies and perineal tears.

There is very little research evidence relating to maternal satisfaction with the management and repair of perineal trauma following childbirth. As highlighted by Walsh 2001, most clinical trials have concentrated on outcomes that are important to professionals and have, on the whole, ignored women's experiences. Only one of the included trials collected information on women's satisfaction with the repair (Kettle 2002). This is potentially an important area for future research, as the longer term impact of perineal trauma and repair may be considerable.

More research is required into evaluating alternative ways of minimising the extent of perineal trauma sustained by women during vaginal delivery and the impact that it has on women's decision to have an elective caesarean section for subsequent births.

There has been limited research carried out to evaluate methods of teaching and assessing surgical skills in obstetrics. More work is required to evaluate the effectiveness and cost implications of using alternative methods of teaching perineal assessment, repair and management skills compared to traditional methods of 'see one, do one, teach one'.

\section{ACKNOWLEDGEMENTS}

Professor Adrian Grant compiled the first version of this review and he provided us with the additional unpublished data from the Olah 1990 trial which he had previously obtained in writing from Karl Olah.

As part of the pre-publication editorial process, this review has been commented on by three peers (an editor and two referees who are external to the editorial team), a member of the Pregnancy and Childbirth Group's international panel of consumers and the Group's Statistical Adviser.

We thank Angela Cooke for translating Gaasemyr 1977, Maria Stoyadinova for translating Nikolov 2006 and S.Yildiz Çinar for translating Uslu 1992. 


\section{RE F E R E N C E S}

\section{References to studies included in this review}

Banninger 1978 \{published data only\}

Banninger $\mathrm{U}$, Buhrig $\mathrm{H}$, Schreiner WE. A comparison between chromic catgut and polyglycolic acid sutures in episiotomy repair. Geburtshilfe und Frauenheilkunde 1978;38:30-3.

\section{Beard 1974 \{published data only\}}

Beard RJ, Boyd I, Sims CD. A trial of polyglycolic acid and chromic catgut sutures in episiotomy repair. British Journal of Clinical Practice 1974;28:409-10.

\section{Dencker 2006 \{published data only\}}

Dencker A, Lundgren I, Sporrong T. Suturing after childbirth a randomised controlled study testing a new monofilament material. BJOG: an international journal of obstetrics and gynaecology 2006;113(1):114-6.

\section{Gemynthe 1996 \{published data only\}}

Gemynthe A, Langhoff-Roos J, Sahl S, Knudsen J. New VICRYL formulation: an improved method of perineal repair?. British Journal of Midwifery 1996;4:230-4.

\section{Greenberg 2004 \{published data only\}}

Greenberg JA, Lieberman E, Cohen AP, Ecker JL. Randomized comparison of chromic versus fast-absorbing polyglactin 910 for postpartum perineal repair. Obstetrics \& Gynecology 2004;103(6):1308-13.

\section{Kettle 2002 \{published data only\}}

Kettle C, Hills RK, Jones P, Darby L, Gray R, Johanson R. Continuous versus interrupted perineal repair with standard or rapidly absorbed sutures after spontaneous vaginal birth: a randomised controlled trial. Lancet 2002;359:2217-23.

\section{Leroux 2006 \{published data only\}}

Leroux N, Bujold E. Impact of chromic catgut versus polyglactin 910 versus fast-absorbing polyglactin 910 sutures for perineal repair: a randomized, controlled trial. American Journal of Obstetrics and Gynecology 2006;194(6):1585-90.

\section{Livingstone 1974 \{published data only\}}

Livingstone E, Simpson D, Naismith WCMK. A comparison between catgut and polyglycolic acid sutures in episiotomy repair. Journal of Obstetrics and Gynaecology of the British Commonwealth 1974;81:245-7.

\section{Mackrodt 1998 \{published data only\}}

Gordon B, Mackrodt C, Fern E, Truesdale A, Ayers S, Grant A. The Ipswich childbirth study: 1 A randomised evaluation of two stage postpartum perineal repair leaving the skin unsutured. British Journal of Obstetrics and Gynaecology 1998;105(4):435-40.

Grant A, Gordon B, Mackrodt C, Fern E, Truesdale A, Ayers S. The Ipswich childbirth study: one year follow up of alternative methods used in perineal repair. BJOG: an international journal of obstetrics and gynaecology 2001;108(1):34-40.
Mackrodt C, Fern E, Gordon B. Ipswich childbirth study perineal suturing study. Proceedings of Research in Midwifery Conference; 1993 Sept 14; Birmingham, UK. 1993.

* Mackrodt C, Gordon B, Fern E, Ayers S, Truesdale A, Grant A. The Ipswich Childbirth Study: 2. A randomised comparison of polyglactin 910 with chromic catgut for postpartum perineal repair. British Journal of Obstetrics and Gynaecology 1998;105:441-5.

Mahomed 1989 \{published data only\}

Mahomed K, Grant AM, Ashurst H, James D. The Southmead perineal suture study. A randomised comparison of suture materials and suturing techniques for repair of perineal trauma. British Journal of Obstetrics and Gynaecology 1989;96:1272-80.

McElhinney 2000 \{published data only\}

McElhinney BR, Glenn DR, Dornan G, Harper MA. Episiotomy repair: Vicryl versus Vicryl Rapide. Ulster Medical Journal 2000;69(1):27-9.

Nikolov 2006 \{published data only\}

Nikolov A, Dimitrov A, Iliev D, Krsteva K. [Repair of episiotomies with synthetic suture material]. [Bulgarian]. Akusherstvo $i$ Ginekologiia 2006;45(7):12-5.

Olah 1990 \{published data only\}

Olah KS. Episiotomy repair - suture material and short term morbidity. Journal of Obstetrics and Gynaecology 1990;10:503-5.

Roberts 1983 \{published data only\}

Roberts ADG, McKay Hart D. Polyglycolic acid and catgut sutures, with and without oral proteolytic enzymes, in the healing of episiotomies. British Journal of Obstetrics and Gynaecology 1983;90:650-3.

Rogers 1974 \{published data only\}

Rogers RE. Evaluation of post-episiorrhaphy pain: polyglycolic acid vs catgut sutures. Military Medicine 1974;139:102-4.

Saint 1993 \{published data only\}

Saint H, Bamford D. Obstetric perineal repair: a comparison between the use of untreated chromic catgut and glycerolimpregnated catgut. Obstetrics and Gynaecology Today 1993;4(3):56-7.

\section{Spencer 1986 \{published data only\}}

Grant AM, Sleep J, Ashurst H, Spencer JAD. Dyspareunia associated with the use of glycerol-impregnated catgut to repair perineal trauma. Report of a 3-year follow-up study. British Journal of Obstetrics and Gynaecology 1989;96:741-3.

* Spencer JAD, Grant AM, Elbourne DR, Garcia J, Sleep J. A randomized comparison of glycerol-impregnated chromic catgut with untreated chromic catgut for the repair of perineal trauma. British Journal of Obstetrics and Gynaecology 1986;93:426-30. 
Upton 2002 \{published data only\}

Upton A, Roberts CL, Ryan M, Faulkner M, Reynolds M, RaynesGreenow $C$. A randomised trial, conducted by midwives, of perineal repairs comparing a polyglycolic suture material and chromic catgut. Midwifery 2002;18(3):223-9.

\section{References to studies excluded from this review}

\section{Gaasemyr 1977 \{published data only\}}

Gaasemyr M, Hovland E, Bergsjo P. The importance of suturing material for healing after episiotomy. Comparison between cromcatgut and supramid. Fra Medisinske Publikasjoner 1977;2:1-5.

\section{Hemsley 1997 \{unpublished data only\}}

Hemsley L. Perineal suturing: vicryl rapide versus plain catgut. Personal communication December 21997.

\section{Ketcham 1994 \{published data only\}}

Ketcham KR, Pastorek JG, Letellier RL. Episiotomy repair: chromic versus polyglycolic acid suture. Southern Medical Journal 1994;87(4):514-7.

\section{Marques 2001 \{published data only\}}

Marques R, Almeida E. Episiorrhaphy comparative study of chromic/vicryl rapide. Journal of Perinatal Medicine 2001;29 Suppl 1(Pt 2):724.

\section{Tompkins 1972 \{published data only\}}

Tompkins MG, Lea RH. The use of polyglycolic acid sutures in obstetrics and gynaecology. Canadian Medical Association Journal 1972;106:675-7.

\section{Uslu 1992 \{published data only\}}

Uslu MA, Ozekici U, Simsek M, Berkman S. A prospective randomized study of three different methods of episiotomy repair. Istanbul Tip Fakultesi Mecumasi 1992;55:237-42.

\section{Wikoff 1992 \{published data only\}}

Wikoff MD, Kuehl TJ, Cooney AT, Knight AB. Comparison of postpartum pain and healing with repair of perineal disruptions using chromic catgut or polyglycolic acid suture. American Journal of Obstetrics and Gynecology 1992;166:409.

\section{Additional references}

\section{Chalmers 1989}

Chalmers I, Hetherington J, Elbourne D, Keirse MJNC, Enkin M. Materials and methods used in synthesizing evidence to evaluate the effects of care during pregnancy and childbirth. In: Chalmers I, Enkin M, Keirse MJNC editor(s). Effective care in pregnancy and childbirth. Oxford: Oxford University Press, 1989:39-65.

\section{Clinical Evidence 2008}

Kettle C, Tohill S. Perineal care. BMJ, Clinical Evidence. Vol. 09, London: BMJ Publishing Group Ltd, 2008:1401.

\section{Craig 1975}

Craig PH, Williams JA, Davis KW, Magoun AD. A biologic comparison of polyglactin 910 and polyglycolic acid synthetic absorbable sutures. Surgery, Gynecology \& Obstetrics 1975;141(1):1-10.

\section{Cuschieri 2000}

Cuschieri A, Steele RJC, Moossa AR. Essential surgical practice. 4th Edition. Oxford: Butterworth-Heinemann, 2000.

\section{Ethicon 1992}

Ethicon. Coated Vicryl Polyglactin 910: the gentle approach. Edinburgh, UK: Ethicon Limited, 1992.

\section{Flanagan 1997}

Flanagan M. Wound management. Edinburgh: Churchill Livingstone, 1997.

\section{Fleming 1990}

Fleming N. Can the suturing material make a difference in postpartum, perineal pain?. Journal of Nurse-Midwifery 1990;35(1):19-25.

\section{Glazener 1995}

Glazener CMA, Abdalla MI, Stroud P, Naji SA, Templeton AA, Russell IT. Postnatal maternal morbidity: extent, causes, prevention and treatment. British Journal of Obstetrics and Gynaecology 1995;102:282-7.

\section{Gordon 1998}

Gordon B, Mackrodt C, Fern E, Truesdale A, Ayers S, Grant A. The Ipswich childbirth study: 1 A randomised evaluation of two stage postpartum perineal repair leaving the skin unsutured. British Journal of Obstetrics and Gynaecology 1998;105(4):435-40.

\section{Graham 1997}

Graham ID. Episiotomy: challenging obstetric interventions. Oxford: Blackwell Science Ltd, 1997.

\section{Grant 1989}

Grant A. Repair of perineal trauma after childbirth. In: Chalmers I, Enkin MW, Keirse MJNC editor(s). Effective care in pregnancy and childbirth. Oxford: Oxford University Press, 1989:1173-5.

\section{Higgins 2008}

Higgins JPT, Green S, editors. Cochrane Handbook for Systematic Reviews of Interventions Version 5.0.1 [updated September 2008]. The Cochrane Collaboration, 2008. Available from www.cochrane-handbook.org.

\section{Howard 1995}

Howard S, McKell D, Mugford M, Grant A. Cost-effectiveness of different approaches to perineal suturing. British Journal of Midwifery 1995;3(11):587-605.

\section{Irvin 1981}

Irvin TT. Wound healing - principles and practices. London: Chapman and Hall, 1981. 


\section{Isager-Sally 1986}

Isager-Sally L, Legarth J, Jacobson B, Bustofte E. Episiotomy repair - immediate and long-term sequelae. A prospective randomised study of three different methods of repair. British Journal of Obstetrics and Gynaecology 1986;93:420-5.

\section{Kettle 2007}

Kettle C, Hills RK, Ismail KMK. Continuous versus interrupted sutures for repair of episiotomy or second degree tears. Cochrane Database of Systematic Reviews 2007, Issue 4. [DOI: 10.1002/14651858.CD000947.pub2]

\section{McCaul 2000}

McCaul LK, Bagg J, Jenkins WMM. Rate of loss of irradiated polyglactin 910 (Vicryl Rapide) from the mouth: a prospective study. British Journal of Oral Maxillofacial Surgery 2000;38:328-30.

\section{Mulrow 1997}

Mulrow CD, Oxman A, editors. Cochrane Collaboration Handbook [updated September 1997]. In: The Cochrane Library [database on disk and CDROM]. The Cochrane Collaboration. Oxford: Update Software; 1997, Issue 4.

\section{NICE 2007}

National Institute for Health and Clinical Excellence (NICE). Intrapartum Guideline No 55 - Care of healthy women and their babies during childbirth. London: NICE, 2007.

\section{Oboro 2003}

Oboro VO, Tabowei TO, Loto Om, Bosah JO. A multicenter evaluation of the two-layer repair of perineal trauma after birth. British Journal of Obstetrics and Gynaecology 2003;1:5-8.

\section{ONS 2001}

Office of National Statistics. Population and Vital Statistics (2000). London: HMSO, 2001.

\section{RCOG 2007}

Royal College of Obstetricians and Gynaecologists. The management of third- and fourth degree perineal tears (Green Top Guideline No. 29). London: RCOG, 2007.

\section{RevMan 2008 [Computer program]}

The Cochrane Collaboration. Review Manager (RevMan). Version 5.0. Copenhagen, The Nordic Cochrane Centre: The Cochrane Collaboration, 2008.

\section{Sleep 1984}

Sleep J, Grant A, Garcia J, Elbourne D, Spencer J, Chalmers I. West Berkshire perineal management trial. BMJ 1984;289:587-90.

\section{CHARACTERISTICS OF STUDIES}

\section{Characteristics of included studies [ordered by study ID]}

\section{Sultan 1996}

Sultan AH, Monga AK, Stanton SL. The pelvic floor sequelae of childbirth. British Journal of Hospital Medicine 1996;55(9):575-579.

\section{Sultan 1999}

Sultan AH. Obstetric perineal injury and anal incontinence. Clinical Risk 1999;5:193-6.

\section{Taylor 1996}

Taylor I, Karran SJ. Surgical principles. 1st Edition. London: Oxford University Press, 1996.

\section{Thacker 1983}

Thacker SB, Banta HD. Benefits and risks of episiotomy: an interpretative review of the English Language literature, 1860-1980. Obstetrical and Gynecological Survey 1983;38:322-38.

\section{Walsh 2001}

Walsh D. Perineal care should be a feminist issue. British Journal of Midwifery 2001;8(12):731-7.

\section{Woolley 1995a}

Woolley RJ. Benefits and risks of episiotomy: a review of the English-language literature since 1980. Part I. Obstetrical and Gynecological Survey 1995;50(11):806-20.

\section{Woolley 1995b}

Woolley RJ. Benefits and risks of episiotomy: a review of the English-language literature since 1980. Part II. Obstetrical and Gynecological Survey 1995;50(11):821-35.

\section{References to other published versions of this review Johanson 1994}

Johanson RB. Polyglycolic acid vs catgut for perineal repair [revised 10 March 1994]. In: Keirse MJNC, Renfrew MJ, Neilson JP, Crowther C (eds). Pregnancy and Childbirth Module. In: The Cochrane Pregnancy and Childbirth Database [database on disk and CDROM]. The Cochrane Collaboration; Issue 2, Oxford: Update Software; 1995.

\section{Kettle 1999}

Kettle $\mathrm{C}$, Johanson R. Absorbable synthetic versus catgut suture material for perineal repair. Cochrane Database of Systematic Reviews 1999, Issue 4. [DOI: 10.1002/14651858.CD000006]

* Indicates the major publication for the study

\section{Banninger 1978}


Banninger 1978 (Continued)

Factorial design ( 3 arm trial, 2 arms compared different materials (polyglycolic acid vs catgut) using the same method of repair; the third arm included mixed materials and mixed methods of repair; we have not included this arm in the analyses).

\begin{tabular}{ll}
\hline Participants & Setting - Zurich, Switzerland. \\
153 women - these were women \\
same suture material (either polyg \\
used throughout the repair. \\
Inclusion criteria - women with a \\
Exclusion criteria - women with a \\
additional damage to the cervix, \\
Parity - primigravida (first-time mot \\
Mean age - intervention group $=$ \\
Operator - doctors. \\
Intervention group ( $\mathrm{n}=80$ - vagi \\
with polyglycolic acid (Dexon) No. \\
Comparison group ( $\mathrm{n}=73$ - vagin \\
with chromic catgut No. 0 on a 60 \\
Short-term pain - day 3 and 7. \\
Analgesia - up to day 7. \\
Suture dehiscence - up to day 7. \\
Resuturing - up to day 7. \\
Dyspareunia - at 3 months.
\end{tabular}

Notes Only one-third of participants followed up at 3 months.

Cosmetic results were reported at 3 months after delivery (data not included in the paper) - the intervention group had less scarring in the form of 'rope ladder' compared to the comparison group.

\section{Risk of bias}

\begin{tabular}{|c|c|c|}
\hline Bias & Authors' judgement & Support for judgement \\
\hline $\begin{array}{l}\text { Adequate sequence gener- } \\
\text { ation? }\end{array}$ & High risk & Allocated by 'alternating sequence'. \\
\hline Allocation concealment? & High risk & $\begin{array}{l}\text { No information available regarding concealment of treatment allocation, but } \\
\text { the alternating randomisation sequence means that group allocation may } \\
\text { have been anticipated. }\end{array}$ \\
\hline $\begin{array}{l}\text { Blinding? } \\
\text { Women }\end{array}$ & Unclear risk & No details given. \\
\hline $\begin{array}{l}\text { Blinding? } \\
\text { Clinical staff }\end{array}$ & High risk & Difference in suture material appearance. \\
\hline $\begin{array}{l}\text { Blinding? } \\
\text { Outcome assessors }\end{array}$ & High risk & Difference in suture material appearance. \\
\hline $\begin{array}{l}\text { Incomplete outcome data } \\
\text { addressed? } \\
\text { All outcomes }\end{array}$ & High risk & $\begin{array}{l}\text { Low attrition for short-term outcomes. At } 3 \text { months follow up only } 30 \% \text { of the } \\
\text { original sample remained. }\end{array}$ \\
\hline
\end{tabular}


Banninger 1978 (Continued)

Free of other bias? Unclear risk No baseline imbalance apparent.

Beard 1974

\begin{tabular}{|c|c|}
\hline Methods & RCT. \\
\hline \multirow[t]{7}{*}{ Participants } & Setting - Queen Charlotte Maternity Hospital, London, UK. \\
\hline & 200 women 'allocated randomly' into 2 groups. \\
\hline & Inclusion criteria - women having a 'normal delivery' with an episiotomy. \\
\hline & Exclusion criteria - women with lacerations or those booked for 48 hour discharge. \\
\hline & Parity - primigravidae and multigravidae. \\
\hline & Mean age - not specified. \\
\hline & Operator - resident obstetric officers in their second obstetric appointment. \\
\hline \multirow[t]{2}{*}{ Interventions } & $\begin{array}{l}\text { Intervention group }(n=100) \text { - 'standard method of repair incorporating a subcuticular suture to the } \\
\text { perineal skin' with polyglycolic acid (Dexon) 2-0 suture material on a } 40 \mathrm{~mm} \text { round bodied atraumatic } \\
\text { needle. }\end{array}$ \\
\hline & $\begin{array}{l}\text { Comparison group }(n=100) \text { - 'standard method of repair incorporating a subcuticular suture to the } \\
\text { perineal skin' with chromic catgut 2-0 suture material on a } 55 \mathrm{~mm} \text { 'loose' round bodied needle. }\end{array}$ \\
\hline \multirow[t]{4}{*}{ Outcomes } & Short-term pain - day 3. \\
\hline & Analgesia - day 3. \\
\hline & Suture dehiscence - day 3 (classified as superficial and deep). \\
\hline & Wound inflammation - day 3. \\
\hline \multirow[t]{3}{*}{ Notes } & Similar number of primigravida and multigravida women in each group. \\
\hline & Method of repair not fully described. \\
\hline & $\begin{array}{l}\text { It was documented in the paper that on the 3rd day after delivery the patients were interviewed and } \\
\text { examined by } 1 \text { of the operators without knowledge of which suture material had been used. This may } \\
\text { have been possible if the skin was closed with a subcuticular suture as the stitches would not be visi- } \\
\text { ble. }\end{array}$ \\
\hline
\end{tabular}

\section{Risk of bias}

\begin{tabular}{|c|c|c|}
\hline Bias & Authors' judgement & Support for judgement \\
\hline $\begin{array}{l}\text { Adequate sequence gener- } \\
\text { ation? }\end{array}$ & Unclear risk & Allocated "randomly to two groups" - method not described. \\
\hline Allocation concealment? & Unclear risk & No information available regarding concealment of treatment allocation. \\
\hline $\begin{array}{l}\text { Blinding? } \\
\text { Women }\end{array}$ & Unclear risk & No details given. \\
\hline $\begin{array}{l}\text { Blinding? } \\
\text { Clinical staff }\end{array}$ & High risk & Difference in suture materials and needles used for the repairs. \\
\hline $\begin{array}{l}\text { Blinding? } \\
\text { Outcome assessors }\end{array}$ & Unclear risk & $\begin{array}{l}\text { Outcome assessors were described as being "without knowledge of which su- } \\
\text { ture had been used". }\end{array}$ \\
\hline
\end{tabular}

Incomplete outcome data Low risk All participants entered into the trial were included in the analysis.

All outcomes 
Beard 1974 (Continued)

Free of other bias? Unclear risk Outcomes relating to pain were not simple to interpret, for 1 measure of pain, event rates added up to more than the total sample size and women may have been counted more than once: this outcome has not been included in the review.

Dencker 2006

\begin{tabular}{|c|c|}
\hline Methods & RCT. \\
\hline \multirow[t]{4}{*}{ Participants } & $\begin{array}{l}\text { Setting - Department of Normal Obstetrics/Ostra, Sahlgrenska University Hospital, Gothenburg, Swe- } \\
\text { den. }\end{array}$ \\
\hline & $\begin{array}{l}1139 \text { women 'randomly allocated'. } \\
\text { Inclusion criteria - women having a vaginal delivery with laceration or episiotomy that required sutur- } \\
\text { ing by a midwife; singleton pregnancy; cephalic presentation and gestation between } 34 \text { and } 42 \text { weeks. } \\
\text { Exclusion criteria - not documented. }\end{array}$ \\
\hline & Parity - primigravida and multigravida. \\
\hline & $\begin{array}{l}\text { Mean age - not documented. } \\
\text { Operator - midwives. }\end{array}$ \\
\hline \multirow[t]{3}{*}{ Interventions } & $\begin{array}{l}\text { Method of repair - both continuous and interrupted suturing techniques were used - each midwife used } \\
\text { the suturing technique she preferred. }\end{array}$ \\
\hline & $\begin{array}{l}\text { Intervention group }(n=554) \text { - monofilament glycomer } 631 \text { (Biosyn) (suture material gauge and size of } \\
\text { needle not documented). }\end{array}$ \\
\hline & $\begin{array}{l}\text { Comparison group ( } n=585 \text { ) - multifilament polyglycolic acid (Dexon II) (suture material gauge and size } \\
\text { of needle not documented). }\end{array}$ \\
\hline
\end{tabular}

Outcomes

INCLUDED IN ANALYSIS

Short-term pain - up to day 3 (data not presented in paper).

Wound healing - up to day 3 (data not presented in paper).

Perineal discomfort/pain - $8-12$ weeks postpartum.

Wound healing - $8-12$ weeks postpartum.

Re-suturing - up to six months postpartum.

Notes

The authors of this study provided additional unpublished data on outcomes.

\section{Risk of bias}

\begin{tabular}{|c|c|c|}
\hline Bias & Authors' judgement & Support for judgement \\
\hline $\begin{array}{l}\text { Adequate sequence gener- } \\
\text { ation? }\end{array}$ & Low risk & 'Random number generator.' \\
\hline Allocation concealment? & Low risk & Opaque, sealed, serially numbered envelopes. \\
\hline $\begin{array}{l}\text { Blinding? } \\
\text { Women }\end{array}$ & Unclear risk & No details given. \\
\hline $\begin{array}{l}\text { Blinding? } \\
\text { Clinical staff }\end{array}$ & High risk & Difference in suture materials. \\
\hline Blinding? & High risk & Difference in suture materials. \\
\hline
\end{tabular}


Dencker 2006 (Continued)

Outcome assessors

\begin{tabular}{lll}
\hline $\begin{array}{l}\text { Incomplete outcome data } \\
\text { addressed? } \\
\text { All outcomes }\end{array}$ & Unclear risk & $\begin{array}{l}\text { Drop-out } n=64 \text { (48 envelopes 'discarded' plus } 16 \text { questionnaires were missing } \\
\text { substantial data). } 93 \% \text { followed up at } 1-3 \text { days and } 64 \% \text { at } 8-12 \text { weeks. }\end{array}$ \\
\hline Free of other bias? & Unclear risk & $\begin{array}{l}\text { The published paper did not provide information on non significant results; } \\
\text { the author provided additional unpublished data on request. }\end{array}$ \\
\hline
\end{tabular}

Gemynthe 1996

\begin{tabular}{|c|c|c|}
\hline Methods & \multicolumn{2}{|l|}{ RCT. } \\
\hline Participants & \multicolumn{2}{|c|}{$\begin{array}{l}\text { Setting - Obstetric Unit, Rigshospitalet, Copenhagen, Denmark. } \\
308 \text { women recruited. } \\
\text { Inclusion criteria - Danish speaking women with a spontaneous perineal tear or episiotomy requiring } \\
\text { suturing. } \\
\text { Exclusion criteria - not documented. }\end{array}$} \\
\hline Interventions & \multicolumn{2}{|c|}{$\begin{array}{l}\text { Method of repair - not described (stated that a continuous subcuticular suture is used in practically all } \\
\text { departments of obstetrics in Denmark). } \\
\text { Intervention group ( } n=155 \text { ) - fast-absorbing polyglactin } 910 \text { suture material (Vicryl Rapide) (suture ma- } \\
\text { terial gauge and size of needle not documented). } \\
\text { Comparison group ( } n=153 \text { ) - standard polyglactin } 910 \text { suture material (Vicryl) (suture material gauge } \\
\text { and size of needle not documented). }\end{array}$} \\
\hline Outcomes & $\begin{array}{l}\text { Pain or discomfort wh } \\
\text { Insufficient healing, vi } \\
\text { Time of resumption of } \\
\text { Dyspareunia at } 3 \text { mon }\end{array}$ & $\begin{array}{l}\text { n sitting, lying, walking and defecation at } 2 \text { days, } 5 \text { days, } 2 \text { weeks and } 3 \text { months. } \\
\text { ble sutures and sutures removed up to } 8 \text { weeks' postpartum healing. } \\
\text { ntercourse - up to } 3 \text { months. } \\
\text { Is postpartum. }\end{array}$ \\
\hline \multicolumn{3}{|l|}{ Notes } \\
\hline \multicolumn{3}{|l|}{ Risk of bias } \\
\hline Bias & Authors' judgement & Support for judgement \\
\hline $\begin{array}{l}\text { Adequate sequence gener- } \\
\text { ation? }\end{array}$ & Unclear risk & $\begin{array}{l}\text { Block randomisation - block size not specified (stratification of randomisation } \\
\text { by episiotomy or laceration). }\end{array}$ \\
\hline Allocation concealment? & Unclear risk & States 'two sets of sealed envelopes'. \\
\hline $\begin{array}{l}\text { Blinding? } \\
\text { Women }\end{array}$ & Low risk & States mothers were not aware of which suture material was used. \\
\hline $\begin{array}{l}\text { Blinding? } \\
\text { Clinical staff }\end{array}$ & High risk & $\begin{array}{l}\text { Obvious differences in colour of suture material and packaging (standard } \\
\text { Vicryl is usually dyed purple and Vicryl Rapide is usually undyed). }\end{array}$ \\
\hline
\end{tabular}


Gemynthe 1996 (Continued)
Blinding?
Unclear risk
States project midwives were not aware of which suture material was used
Outcome assessors (this may be possible in subcutaneous stitches were used). The woman's GP performed the check-up at 2 months postpartum and was 'unaware of the su- ture material used'.

\begin{tabular}{|c|c|c|}
\hline $\begin{array}{l}\text { Incomplete outcome data } \\
\text { addressed? }\end{array}$ & Unclear risk & $\begin{array}{l}\text { Some missing data at all data collection points (pain data } 2.9 \% \text { missing at } 48 \\
\text { hrs. } 11.7 \% \text { at } 2 \text { weeks and } 24 \% \text { at } 3 \text { months). }\end{array}$ \\
\hline
\end{tabular}

Free of other bias? Low risk No other bias apparent.

Greenberg 2004

\begin{tabular}{ll}
\hline Methods & RCT (block randomisation). \\
\hline Participants & Setting - Brigham \& Women's Hospital and the Massachusetts General Hospital, USA. \\
& 1361 women enrolled - only two-thirds ( $\mathrm{n}=908)$ required suturing of vulval and/or vaginal laceration; \\
and/or episiotomy. & Inclusion criteria - women presenting in labour or for induction. \\
& Exclusion criteria - not documented. \\
& Parity - primigravida and multigravida \\
& Maternal age - not documented. \\
& Operator - obstetricians and midwives.
\end{tabular}

\begin{tabular}{ll}
\hline Interventions & Method of repair - (not fully described) all practitioners used subcuticular skin closure except 1 opera- \\
& tor who used interrupted technique. \\
& Intervention group $(\mathrm{n}=459)$ - fast-absorbing polyglactin 910 (gauge of material and needle size not \\
specified). \\
Comparison group $(\mathrm{n}=449)$ - chromic catgut (gauge of material and needle size not specified).
\end{tabular}

\begin{tabular}{|c|c|}
\hline Outcomes & $\begin{array}{l}\text { INCLUDED IN ANALYSIS } \\
\text { Vaginal pain - } 24 \text { - } 48 \text { hrs; } 10-14 \text { days; } 6-8 \text { weeks postpartum. } \\
\text { Uterine pain - } 24 \text { - } 48 \text { hrs; } 10-14 \text { days; 6-8 weeks postpartum. } \\
\text { Analgesia (used in last } 8 \text { hrs) } 24 \text { - } 48 \text { hrs; } 10-14 \text { days; 6-8 weeks postpartum. } \\
\text { Painless bowel movement - } 24 \text { - } 48 \text { hrs; } 10-14 \text { days; } 6-8 \text { weeks postpartum. } \\
\text { Resuturing - up to day } 7 . \\
\text { Perineal wound breakdown at 6-8 weeks. } \\
\text { Dyspareunia - at } 3 \text { months. }\end{array}$ \\
\hline
\end{tabular}

Notes $\quad 87 \%$ of participants received allocated suture material.

\section{Risk of bias}

\begin{tabular}{lll}
\hline Bias & Authors' judgement & Support for judgement \\
\hline $\begin{array}{l}\text { Adequate sequence gener- } \\
\text { ation? }\end{array}$ & Low risk & $\begin{array}{l}\text { Treatment allocated by block randomisation (block size 10) using validated } \\
\text { SAS program (Cary, NC). }\end{array}$ \\
\hline Allocation concealment? & Low risk & Numbered opaque sealed envelopes. \\
\hline $\begin{array}{l}\text { Blinding? } \\
\text { Women }\end{array}$ & High risk & Stated that 'women were not blinded to suture material used'. \\
\hline Blinding? & High risk & Unable to 'blind' operators due to obvious difference in suture material.
\end{tabular}


Greenberg 2004 (Continued)

Clinical staff

\begin{tabular}{|c|c|c|}
\hline $\begin{array}{l}\text { Blinding? } \\
\text { Outcome assessors }\end{array}$ & Unclear risk & $\begin{array}{l}\text { Stated 'nurses were blinded to suture material used when asking questions at } \\
24-48 \text { hrs and } 10-14 \text { days postpartum'. }\end{array}$ \\
\hline
\end{tabular}

Incomplete outcome data Unclear risk 1361 women randomised, however, only 908 women required perineal repair addressed? and were included in analysis.

All outcomes

Intention-to-treat analysis carried out amongst women who received sutures (women were recruited prior to delivery and therefore some women did not require perineal suturing).

$64 \%$ of participants were lost to follow up at 6-8 weeks postpartum.

\begin{tabular}{ll}
\hline Free of other bias? & Unclear risk \\
analysis by randomisation group for those women requiring repair.
\end{tabular}

Kettle 2002

Methods RCT.

Factorial $2 \times 2$ design.

Participants Setting - University Hospital of North Staffordshire, UK.

1542 women randomised.

Inclusion criteria - women who had a spontaneous vaginal delivery with a second-degree tear or episiotomy, who had given their preliminary informed consent.

Exclusion criteria - instrumental vaginal delivery; extensive perineal trauma beyond the midwife's scope of practice; previous perineal surgery other than primary repair after childbirth; delivery of a stillborn infant or baby with extensive congenital abnormalities; women with AIDS or hepatitis B virus infection, severe perineal warts or extensive varicose veins of the genital area; women who were younger than 16 years and those unable to read, write or understand English language.

Parity - primigravida and multigravida.

Mean age - intervention group $=27.3 ;$ comparison group $=27.1$.

Operators - midwives $(n=150)$ ( 29 women sutured by a doctor).

Interventions $\quad$ Method of repair - described as below.

Intervention group $(\mathrm{n}=772$ ) - un-dyed fast-absorbing polyglactin 910 (Vicryl Rapide) 2/0 on a $35 \mathrm{~mm}$ tapercut needle ( $50 \%$ had vaginal trauma, perineal muscle and skin repaired with a continuous non-locking suture technique and $50 \%$ had vaginal trauma repaired with a locking continuous stitch; perineal muscle and skin sutured using the interrupted method).

Comparison group $(n=770)$ un-dyed standard polyglactin 910 (Vicryl) on a $35 \mathrm{~mm}$ tapercut needle (50\% had vaginal trauma, perineal muscle and skin repaired with a continuous non-locking suture technique and $50 \%$ had vaginal trauma repaired with a locking continuous stitch; perineal muscle and skin sutured using the interrupted method).

Outcomes

Short-term pain - day 2 and 10.

Pain when walking, sitting, passing urine, opening bowels at 10 days.

Analgesia - day 10.

Long-term pain - 3 months and 12 months.

Dyspareunia -3 and 12 months.

Removal of suture material and resuturing before 3 months; sutures uncomfortable; sutures tight; wound gaping; satisfaction with the repair and feeling back to normal within 3 months of birth. 
Kettle 2002 (Continued)

Notes

Treatment envelopes were packed by Birmingham Clinical Trials Unit (envelopes contained 2 packets of masked suture material and instructions for method of repair on different coloured cards).

Concealed interim analysis after 400 women entered the trial.

Ethics Committee Approval.

9 women with a third degree tear and 1 with a fourth degree tear were recruited in error but were included in the analysis.

\section{Risk of bias}

\begin{tabular}{|c|c|c|}
\hline Bias & Authors' judgement & Support for judgement \\
\hline $\begin{array}{l}\text { Adequate sequence gener- } \\
\text { ation? }\end{array}$ & Low risk & $\begin{array}{l}\text { By external trials unit - computer-generated random permuted block with } \\
\text { block size of } 20 \text { ( } 5 \text { of each treatment combination). }\end{array}$ \\
\hline Allocation concealment? & Low risk & Serially numbered, sealed opaque envelopes \\
\hline $\begin{array}{l}\text { Blinding? } \\
\text { Women }\end{array}$ & Low risk & The suture material was masked at source (suture material looked the same). \\
\hline $\begin{array}{l}\text { Blinding? } \\
\text { Clinical staff }\end{array}$ & Low risk & $\begin{array}{l}\text { The suture material was masked at source (suture material looked the same, } \\
\text { packed in identical packets and coded to prevent identification). (Not possible } \\
\text { to blind the suturing technique.) }\end{array}$ \\
\hline $\begin{array}{l}\text { Blinding? } \\
\text { Outcome assessors }\end{array}$ & Low risk & $\begin{array}{l}\text { The suture material was masked at source (suture material looked the same, } \\
\text { packed in identical packets and coded to prevent identification). }\end{array}$ \\
\hline $\begin{array}{l}\text { Incomplete outcome data } \\
\text { addressed? } \\
\text { All outcomes }\end{array}$ & Low risk & $\begin{array}{l}\text { Only } 3 \text { women did not complete a questionnaire at day } 10 \text {. } \\
\text { Response rate high at each time-point throughout the study. } \\
\text { One envelope unaccounted for. } \\
96.7 \% \text { response rate at } 3 \text { months and } 90 \% \text { at } 12 \text { months. }\end{array}$ \\
\hline Free of other bias? & Low risk & $\begin{array}{l}\text { No other bias apparent; most women received suture material according to } \\
\text { randomisation group. }\end{array}$ \\
\hline
\end{tabular}

Leroux 2006

\begin{tabular}{ll}
\hline Methods & RCT - 3-arm trial. \\
\hline Participants & Setting - not clear - Tertiary care hospital (first author from Canada). \\
& 192 women - spontaneous or operative vaginal delivery and enrolled in early labour or when comfort- \\
& able under regional anaesthesia. \\
& Inclusion criteria - haemodynamically stable patients with a second-degree perineal laceration or an \\
& uncomplicated episiotomy (median or mediolateral) and maternal age $\geq 18$ years. \\
& Exclusion criteria - third- and fourth-degree perineal lacerations; allergy to non-steroidal anti-inflam- \\
& matory agents or aspirin; thrombocytopenia; pregnancy induced hypertension; a history of coagulation \\
& disorders; unexplained haemorrhage or gastroduodenal ulcer. \\
& Parity - primigravida and multigravida. \\
& Mean age - group A = 29.7; group B = 30.5; group C = 30.2. \\
& Operator - obstetrician/gynaecologist or resident under direct supervision.
\end{tabular}

Interventions

Method of repair - continuous technique as described in Williams Obstetrics textbook (2001). 2-0 gauge suture material used for continuous suturing of vagina; 2 - 4 interrupted sutures inserted using a 2-0 
Leroux 2006 (Continued)

gauge suture material to approximate perineal muscle and continuous 3 - 0 gauge suture material to close superficial fascia and skin (same technique used for all 3 groups).

Participants divided into 3 groups:

group A ( $n=66)$ - chromic catgut 2-0 and 3-0 gauge (size and type of needle not documented);

group B $(n=60)$ - standard polyglactin 910 (Vicryl) (size and type of needle not documented);

group C ( $n=66)$ - fast-absorbing polyglactin 910 (Vicryl Rapide) (size and type of needle not documented).

Outcomes Short-term pain - 36 to $48 \mathrm{hrs}$ postpartum.

Analgesia - 36 to 48 hrs.

Pain - 6 weeks and 3 months; breastfeeding - 6 weeks and 3 months; dyspareunia before pregnancy; resumption of sexual intercourse - 6 weeks and 3 months; pain free of sexual intercourse - 6 weeks; residual suture - 6 weeks; incomplete healing - 6 weeks.

Notes

Risk of bias

\begin{tabular}{|c|c|c|}
\hline Bias & Authors' judgement & Support for judgement \\
\hline $\begin{array}{l}\text { Adequate sequence gener- } \\
\text { ation? }\end{array}$ & Unclear risk & 'Assigned randomly.' \\
\hline Allocation concealment? & Low risk & Consecutively numbered opaque envelopes (not stated if sealed). \\
\hline $\begin{array}{l}\text { Blinding? } \\
\text { Women }\end{array}$ & Unclear risk & Stated 'women not informed of the treatment allocation'. \\
\hline $\begin{array}{l}\text { Blinding? } \\
\text { Clinical staff }\end{array}$ & High risk & Unable to 'blind' due to differences in suture material \\
\hline $\begin{array}{l}\text { Blinding? } \\
\text { Outcome assessors }\end{array}$ & Unclear risk & $\begin{array}{l}\text { Stated 'colour of suture were approximately the same therefore difficult to dif- } \\
\text { ferentiate type of material at } 48 \text { hrs and } 6 \text { weeks after delivery' }\end{array}$ \\
\hline $\begin{array}{l}\text { Incomplete outcome data } \\
\text { addressed? } \\
\text { All outcomes }\end{array}$ & Unclear risk & $\begin{array}{l}5 \% \text { missing data at } 36-48 \mathrm{hrs} \text {. } \\
20 \% \text { attrition at } 6 \text { weeks and } 40 \% \text { at } 12 \text { weeks. }\end{array}$ \\
\hline Free of other bias? & Unclear risk & $\begin{array}{l}\text { Premature discontinuation of the study due to catgut being withdrawn from } \\
\text { the 'hospital inventory' for reasons not related to the trial. }\end{array}$ \\
\hline
\end{tabular}

Livingstone 1974

\begin{tabular}{ll}
\hline Methods & Quasi-randomised trial. \\
\hline Participants & Setting - Queen Mother's Hospital, Glasgow. \\
& 100 women randomised. \\
& Inclusion criteria - first-time mothers having spontaneous vaginal, rotation forceps, forceps or ven- \\
touse with a medio-lateral episiotomy. \\
Exclusion criteria - women with additional lacerations or extended episiotomy. \\
Parity - primigravidae. \\
Mean age - not specified. \\
Operators - not specified.
\end{tabular}


Livingstone 1974 (Continued)

Interventions
Method of repair - standard continuous suture of vaginal epithelium and interrupted sutures for muscle layers and skin (for purpose of comparison similar gauge of suture material and size of needle was used).

Intervention group $(n=50)$ sutured with polyglycolic acid No. 1 on a $40 \mathrm{~mm}$ round bodied needle (vaginal and muscle) and No. 0 polyglycolic acid on a $37 \mathrm{~mm}$ diamond taper needle (skin).

Comparison group $(n=50)$ sutured with plain catgut No. 1 on a $40 \mathrm{~mm}$ round bodied needle (vaginal and muscle) and No. 0 plain catgut on a $35 \mathrm{~mm}$ tapercut needle (skin).

Short-term pain - day 3.

Suture dehiscence - day 3 (introital dehiscence and total superficial dehiscence).

Ease of movement - day 3.

Oedema - day 3.

Notes

\section{Risk of bias}

\begin{tabular}{lll}
\hline Bias & Authors' judgement & Support for judgement \\
\hline $\begin{array}{l}\text { Adequate sequence gener- } \\
\text { ation? }\end{array}$ & Unclear risk & $\begin{array}{l}\text { Allocated by quasi-randomisation - 'treatment allocation was determined on a } \\
\text { random basis by drawing lottery cards'. }\end{array}$ \\
\hline
\end{tabular}

\begin{tabular}{lll}
\hline Allocation concealment? & Unclear risk & No information available regarding concealment of treatment allocation. \\
\hline $\begin{array}{l}\text { Blinding? } \\
\text { Women }\end{array}$ & Unclear risk & Not stated. \\
\hline $\begin{array}{l}\text { Blinding? } \\
\text { Clinical staff }\end{array}$ & Unclear risk & $\begin{array}{l}\text { Described as "double blind" but not convinced that blinding was possible due } \\
\text { to obvious differences in suture materials. }\end{array}$ \\
\hline $\begin{array}{l}\text { Blinding? } \\
\text { Outcome assessors }\end{array}$ & Unclear risk & $\begin{array}{l}\text { Researchers stated that by day } 3 \text { catgut had lost its distinguishing colour and } \\
\text { was identical in appearance to Dexon, thus allowing the assessment to be de- } \\
\text { scribed as 'double-blind'. However, this is not convincing because interrupt- } \\
\text { ed sutures were used to appose the perineal skin and any differences in the su- } \\
\text { ture material would be obvious. }\end{array}$
\end{tabular}

\begin{tabular}{ll}
\hline $\begin{array}{l}\text { Incomplete outcome data } \\
\text { addressed? }\end{array}$ & Unclear risk \\
All participants entered into the trial were included in the analysis but it was \\
not clear whether analysis was by 'intention to treat'.
\end{tabular}

All outcomes

Free of other bias? Low risk No other bias apparent.

\section{Mackrodt 1998}

\begin{tabular}{ll}
\hline Methods & RCT. \\
& Factorial $2 \times 2$ design. \\
\hline Participants & Setting - Ipswich Hospital (NHS Trust), Ipswich, UK. \\
& 1780 women randomised. \\
& Inclusion criteria - initially women who sustained an episiotomy or laceration (first or second degree) \\
during a spontaneous vaginal delivery and had given their informed consent to participate were includ- \\
ed. However, the trial was extended to include women who were delivered by a simple instrumental \\
delivery (nonrotational forceps or vacuum extraction).
\end{tabular}


Exclusion criteria - not documented.

Parity - primigravida and multigravida included (split equally between groups).

Mean age - intervention group $=28.2$; comparison group $B=28.4$.

Operator - midwives and doctors.

Interventions

Method of repair - each group had $50 \%$ of women randomly assigned for perineal repair using a 2stage (skin unsutured) technique and 50\% assigned for perineal repair using the 3-stage (skin sutured) method.

Intervention group $(n=889)$ - sutured with polyglactin 910 (Vicryl), gauge 2-0 on $35 \mathrm{~mm}$ needle.

Control group $(n=891)$ - sutured with chromic catgut on $40 \mathrm{~mm}$ needle.

Short-term pain - day 2 and 10.
Analgesia - day 2 and 10 and 3 months.
Tight stitches - 2 and 10 days.
Removal of sutures - 10 days and 3 months.
Resumption of sexual intercourse - 3 months.
Failure to achieve pain-free intercourse - 3 months.
Suture dehiscence - day 10 and 3 months (appearance of perineum, gaping, healing by first intention,
healing by secondary intention, breaking down at 10 days and resuturing at 3 months).

Notes

The operator could 'choose' method of repair for perineal skin (subcutaneous or interrupted). In the group that had the perineal skin sutured $-26 \%$ had subcuticular stitches inserted; $72 \%$ had interrupted transcutaneous stitches; $1 \%$ had skin left unsutured and $1 \%$ had no sutures.

6 women who had a third degree laceration were recruited in error but were included in the analysis.

Interim analysis carried out.

\section{Risk of bias}

\begin{tabular}{lll}
\hline Bias & Authors' judgement & Support for judgement \\
\hline $\begin{array}{l}\text { Adequate sequence gener- } \\
\text { ation? }\end{array}$ & Low risk & $\begin{array}{l}\text { Allocated randomly using balanced blocks varying in size between } 4 \text { and } 12 \text { - } \\
\text { stratified by type of delivery. }\end{array}$ \\
\hline Allocation concealment? & Low risk & $\begin{array}{l}\text { Concealed treatment allocation - serially numbered; sealed opaque envelopes } \\
\text { containing allocation details, suture material and data sheet. } \\
\text { All envelopes accounted for. }\end{array}$ \\
\hline $\begin{array}{l}\text { Blinding? } \\
\text { Women }\end{array}$ & Unclear risk & No details given. \\
\hline $\begin{array}{l}\text { Blinding? } \\
\text { Clinical staff }\end{array}$ & High risk & $\begin{array}{l}\text { Unable to blind operator due to obvious difference in suture methods and ma- } \\
\text { terials. }\end{array}$ \\
\hline $\begin{array}{l}\text { Blinding? } \\
\text { Outcome assessors }\end{array}$ & High risk & $\begin{array}{l}\text { Outcome assessment not fully blinded (unable to fully blind outcome assess- } \\
\text { ment due to obvious difference in suture methods and materials). }\end{array}$ \\
\hline $\begin{array}{l}\text { Incomplete outcome data } \\
\text { addressed? }\end{array}$ & Low risk & $\begin{array}{l}\text { 99\% completed questionnaires at 24-48 hours and 93\% at 3 months postpar- } \\
\text { tum. }\end{array}$ \\
\hline \begin{tabular}{l} 
Free of other bias? \\
\hline
\end{tabular} & Low risk & \begin{tabular}{l} 
No baseline imbalance apparent. \\
\hline
\end{tabular}
\end{tabular}

Mahomed 1989

Methods RCT.


Mahomed 1989 (Continued)

Modified factorial $-2 \times 3 \times 2$ design.

Participants Setting - Southmead Hospital, Bristol, UK.

538 women needing perineal repair following delivery (all tears and episiotomies included). This was a subgroup of the main trial and included only those women who had the same material, either polygly-

colic acid or catgut, used throughout the repair.

Method of delivery - spontaneous and operative vaginal deliveries.

Parity - primigravidae and multipara.

Mean age - intervention group $=26.0$; comparison group $=26.1$.

Operators - midwives, senior house officers, registrars, consultants, medical students.

Interventions Method of repair - continuous suture for vaginal epithelium and interrupted sutures for muscle layers. Skin was sutured with either the interrupted or continuous subcuticular method.

Intervention group $(n=275)$ sutured with polyglycolic acid (Dexon plus) gauge $2-0$ on a $30 \mathrm{~mm}$, half-circle multipurpose needle.

Comparison group $(n=263)$ sutured with chromic catgut gauge 2-0 on a $35 \mathrm{~mm}$, half-circle tapercut needle.

$\begin{array}{ll}\text { Outcomes } & \text { Short-term pain - day } 3 . \\ & \text { Long-term pain - } 3 \text { months. } \\ & \text { Analgesia - up to day } 7 . \\ & \text { Resuturing - up to } 3 \text { months. } \\ & \text { Dyspareunia - } 3 \text { months. } \\ & \text { Removal of suture material - up to } 3 \text { months. }\end{array}$

\begin{tabular}{ll}
\hline Notes & No interim analysis. \\
& Ethics committee approval. \\
& Preset trial size had $80 \%$ chance of detecting significant clinical differences.
\end{tabular}

\section{Risk of bias}

\begin{tabular}{|c|c|c|}
\hline Bias & Authors' judgement & Support for judgement \\
\hline $\begin{array}{l}\text { Adequate sequence gener- } \\
\text { ation? }\end{array}$ & Low risk & Randomly allocated. \\
\hline Allocation concealment? & Low risk & $\begin{array}{l}\text { Concealed treatment allocation - serially numbered, sealed opaque envelopes } \\
\text { (envelopes contained suture material and instructions for method of repair). } \\
22 \text { envelopes were unaccounted for. }\end{array}$ \\
\hline $\begin{array}{l}\text { Blinding? } \\
\text { Women }\end{array}$ & Unclear risk & No details given. \\
\hline $\begin{array}{l}\text { Blinding? } \\
\text { Clinical staff }\end{array}$ & High risk & $\begin{array}{l}\text { Blinding not possible due to obvious differences in suture materials and tech- } \\
\text { niques. }\end{array}$ \\
\hline $\begin{array}{l}\text { Blinding? } \\
\text { Outcome assessors }\end{array}$ & High risk & $\begin{array}{l}\text { Acknowledged that fully blind assessment was not possible due to obvious dif- } \\
\text { ferences in suture materials and techniques. }\end{array}$ \\
\hline $\begin{array}{l}\text { Incomplete outcome data } \\
\text { addressed? } \\
\text { All outcomes }\end{array}$ & Low risk & $\begin{array}{l}1574 \text { women randomised and data available for } 97 \% \text { at day } 2,86 \% \text { at day } 10 \\
\text { and } 87 \% \text { at } 3 \text { months follow up. }\end{array}$ \\
\hline Free of other bias? & Unclear risk & $\begin{array}{l}\text { Factorial design meant that some of the results were difficult to interpret. Un- } \\
\text { published data relating to the comparison of polyglycolic acid versus catgut } \\
\text { were obtained directly from Professor Adrian Grant. }\end{array}$ \\
\hline
\end{tabular}


McElhinney 2000

\begin{tabular}{ll}
\hline Methods & RCT. \\
\hline Participants & Setting - Ulster Hospital, Dundonald, No \\
& 153 women randomised. \\
& Inclusion criteria - women with a parity \\
a normal vaginal delivery and required an & perineal muscle). \\
& Exclusion criteria - not documented. \\
& Parity - primigravida and multigravida. \\
& Maternal age - 18 to 40 years. \\
& Operator - not documented.
\end{tabular}

Interventions Method of repair - all repairs carried out using the same technique with 1 length of suture material and subcuticular perineal skin closure. Method not fully described.

Intervention group $(n=75)$ - fast-absorbing polyglactin 910 (Vicryl Rapide) (gauge of material and needle size not specified).

Comparison group $(n=78)$ - standard polyglactin 910 (Vicryl) (gauge of material and needle size not specified).

$\begin{array}{ll}\text { Outcomes } & \text { Perineal pain - } 24 \text { hrs and } 3 \text { days. } \\ & \text { Analgesia at } 3 \text { days. } \\ \text { Wound infection, gaping wound (no data), suture removal - } 6 \text { and } 12 \text { weeks. } \\ \text { Dyspareunia - } 6 \text { and } 12 \text { weeks postpartum. } \\ \text { Notes } & \begin{array}{l}\text { All women received a diclofenac suppository }(100 \mathrm{mg}) \text { for pain relief, following completion of the re- } \\ \text { pair. }\end{array}\end{array}$

\section{Risk of bias}

\begin{tabular}{|c|c|c|}
\hline Bias & Authors' judgement & Support for judgement \\
\hline $\begin{array}{l}\text { Adequate sequence gener- } \\
\text { ation? }\end{array}$ & Unclear risk & Treatment allocated by block randomisation (block size not clear). \\
\hline Allocation concealment? & Unclear risk & "Two sets of sealed envelopes." \\
\hline $\begin{array}{l}\text { Blinding? } \\
\text { Women }\end{array}$ & Unclear risk & Not stated. \\
\hline $\begin{array}{l}\text { Blinding? } \\
\text { Clinical staff }\end{array}$ & Unclear risk & $\begin{array}{l}\text { Not stated, however, this would be difficult due to possible differences in su- } \\
\text { ture materials. }\end{array}$ \\
\hline $\begin{array}{l}\text { Blinding? } \\
\text { Outcome assessors }\end{array}$ & Unclear risk & Not stated. \\
\hline
\end{tabular}

$\begin{aligned} & \text { Incomplete outcome data } \\
& \text { addressed? } \\
& \text { All outcomes }\end{aligned}$
\begin{tabular}{lll} 
Free of other bias? & Unclear risk & \\
\hline
\end{tabular}


Nikolov 2006

\begin{tabular}{ll} 
Methods & Not clear. ? Quasi-randomised trial. 180 women separated into 3 groups of 60. \\
\hline Participants & $\begin{array}{l}180 \text { women (120 used in the analysis in the review) after episiotomy repair. Women who had had spon- } \\
\text { taneous tearing or anal sphincter repair were not included. } \\
\text { Parity, age and method of repair not described. }\end{array}$ \\
\hline Interventions & Intervention group: polyglactin 910 sutures (Vicryl-Rapide) (60 women). \\
& Comparison group: polyglycolic acid sutures (60 women). \\
& (Women (60) in the third arm of this trial had mixed materials - catgut and silk - and are not included in \\
the analysis.)
\end{tabular}

Notes

The paper was not published in English and translation notes were used for data extraction.

\section{Risk of bias}

\begin{tabular}{lll}
\hline Bias & Authors' judgement & Support for judgement \\
\hline $\begin{array}{l}\text { Adequate sequence gener- } \\
\text { ation? }\end{array}$ & Unclear risk & No information (bias assessed from translation notes). \\
\hline Allocation concealment? & Unclear risk & "separated into 3 groups of 60." \\
\hline $\begin{array}{ll}\text { Blinding? } \\
\text { Women }\end{array}$ & Unclear risk & Not specified. \\
\hline $\begin{array}{l}\text { Incomplete outcome data } \\
\text { addressed? } \\
\text { All outcomes }\end{array}$ & Unclear risk & No missing data apparent. \\
\hline
\end{tabular}

Olah 1990

\begin{tabular}{ll}
\hline Methods & Quasi-randomised trial. \\
\hline Participants & Setting - Selly Oak Hospital, Birmingham. \\
& 120 women randomised. \\
& Inclusion criteria - episiotomy repair following an instrumental delivery (forceps or ventouse extrac- \\
tion). & Exclusion criteria - details not documented. \\
& Parity - primigravida and multigravida. \\
& Mean age - intervention group $=27.0 ;$ control group $=26.5$ \\
& Operators - single operator familiar with technique. \\
\hline
\end{tabular}

Interventions

Method of repair - continuous non-locking stitch with subcuticular to skin (similar method as described by Isager-Sally 1986).

Intervention group $(\mathrm{n}=60)$ polyglycolic acid (Dexon) gauge 0 (needle size not specified). 
Olah 1990 (Continued)

Comparison group $(n=60)$ chromic catgut gauge 0 (needle size not specified).

\begin{tabular}{|c|c|c|}
\hline Outcomes & \multicolumn{2}{|c|}{$\begin{array}{l}\text { Short-term pain - day } 3 \text { and } 5 . \\
\text { Dehiscence of wound - day } 5 . \\
\text { Removal of suture material - day } 5 . \\
\text { Resuturing - day } 5 . \\
\text { Oedema - day } 5 \\
\text { Bruising - day } 5 .\end{array}$} \\
\hline Notes & \multicolumn{2}{|c|}{$\begin{array}{l}\text { No long-term follow up. } \\
\text { Additional information included in the review was obtained directly from the author. }\end{array}$} \\
\hline \multicolumn{3}{|l|}{ Risk of bias } \\
\hline Bias & Authors' judgement & Support for judgement \\
\hline $\begin{array}{l}\text { Adequate sequence gener- } \\
\text { ation? }\end{array}$ & High risk & Odd and even case note numbers. \\
\hline Allocation concealment? & High risk & $\begin{array}{l}\text { Not concealed therefore, treatment allocation could be anticipated in ad- } \\
\text { vance. }\end{array}$ \\
\hline $\begin{array}{l}\text { Blinding? } \\
\text { Women }\end{array}$ & Unclear risk & Not stated. \\
\hline $\begin{array}{l}\text { Blinding? } \\
\text { Clinical staff }\end{array}$ & High risk & Blinding not possible due to obvious differences in suture materials. \\
\hline $\begin{array}{l}\text { Blinding? } \\
\text { Outcome assessors }\end{array}$ & High risk & Blinding not possible due to obvious differences in suture materials. \\
\hline $\begin{array}{l}\text { Incomplete outcome data } \\
\text { addressed? } \\
\text { All outcomes }\end{array}$ & Low risk & No loss to follow up apparent. \\
\hline Free of other bias? & Low risk & Women in the 2 groups were described as being similar at baseline. \\
\hline
\end{tabular}

Roberts 1983

\begin{tabular}{ll}
\hline Methods & RCT. \\
\hline Participants & Setting - Stobhill General Hospital, Glasgow, UK. \\
& 190 women randomised. \\
& Inclusion criteria - all women who had either a spontaneous vaginal delivery or forceps with an epi- \\
& siotomy. \\
& Exclusion criteria - no details given. \\
& Parity - not stated.. \\
& Mean age - not specified. \\
& Operator - not clear.
\end{tabular}

Interventions

Method of repair - continuous suture to close vaginal epithelium and interrupted sutures for muscle layers and skin (buried knots). 
Intervention group $(\mathrm{n}=88$ ) vagina and muscle sutured with polyglycolic acid (Dexon gauge1-0) and skin sutured with polyglycolic acid (Dexon gauge2-0) using an interrupted technique and buried knots.

Comparison group $(n=84)$ vagina and muscle sutured with chromic catgut (gauge1-0) and skin sutured with plain catgut (gauge $2-0$ ) using an interrupted technique and buried knots.

\begin{tabular}{ll}
\hline Outcomes & Short-term pain on rest - 1 to 10 days. \\
& Short-term pain on movement - 1 to 10 days. \\
Analgesia - up to day 5. \\
Bruising - day 2 and 4. \\
Oedema - day 2 and 4. \\
\hline Notes & Not clear if all repairs were carried out by a single investigator. Patients were assessed daily for 5 days \\
after delivery by the obstetrician. \\
Assessed at home on tenth day by district midwife.
\end{tabular}

\section{Risk of bias}

\begin{tabular}{|c|c|c|}
\hline Bias & Authors' judgement & Support for judgement \\
\hline $\begin{array}{l}\text { Adequate sequence gener- } \\
\text { ation? }\end{array}$ & Unclear risk & Allocated by a "randomisation schedule". \\
\hline Allocation concealment? & Unclear risk & No information available regarding concealment of treatment allocation. \\
\hline $\begin{array}{l}\text { Blinding? } \\
\text { Women }\end{array}$ & Unclear risk & Described as "double-blind trial". \\
\hline $\begin{array}{l}\text { Blinding? } \\
\text { Clinical staff }\end{array}$ & Unclear risk & This would be difficult due to differences in suture materials \\
\hline $\begin{array}{l}\text { Blinding? } \\
\text { Outcome assessors }\end{array}$ & Unclear risk & This would be difficult due to differences in suture materials. \\
\hline $\begin{array}{l}\text { Incomplete outcome data } \\
\text { addressed? } \\
\text { All outcomes }\end{array}$ & Unclear risk & $\begin{array}{l}18 \text { of } 190 \text { women randomised were excluded from the analysis because 'they } \\
\text { were unable to complete the study due to being discharged early or tablets } \\
\text { were lost'. Authors state that loss was balanced across groups. }\end{array}$ \\
\hline Free of other bias? & Unclear risk & Women in the 2 study groups were described as having similar characteristics. \\
\hline
\end{tabular}

\section{Rogers 1974}

\begin{tabular}{ll} 
Methods & RCT. \\
\hline Participants & Setting - Department of Obstetrics and Gynecology, Madigan Army Centre, Tacoma, Washington, USA. \\
& 600 women randomised. \\
& Inclusion criteria - women who had a median and medio-lateral episiotomies (episiotomies with lacer- \\
ations also included). \\
Exclusion criteria - not documented. \\
Method of delivery - not clear, defined as complicated or not complicated. \\
Parity - not specified. \\
Mean age - intervention group $=23.45 ;$ comparison group $=22.81$. \\
Operators - not specified.
\end{tabular}


Rogers 1974 (Continued)

Interventions
Method of repair - not described.

Intervention group $(n=301$ ) sutured with chromic catgut (gauge $3-0)$, needle size not specified.

Comparison group ( $n=299$ ) sutured with polyglycolic acid (Dexon) (gauge 3-0), needle size not specified.

Short-term pain - period of time not specified.
Pain in relation to type of episiotomy.
Wound healing at 6 weeks' postpartum (unsure how this was assessed/followed up).

Notes Period of follow up not specified.

\section{Risk of bias}

\begin{tabular}{lll}
\hline Bias & Authors' judgement & Support for judgement \\
\hline $\begin{array}{l}\text { Adequate sequence gener- } \\
\text { ation? }\end{array}$ & Unclear risk & Allocated using 'random technique'. \\
\hline Allocation concealment? & Unclear risk & Suture packs were inside sealed plain envelopes. \\
\hline $\begin{array}{l}\text { Blinding? } \\
\text { Women }\end{array}$ & Unclear risk & Not documented. \\
\hline $\begin{array}{l}\text { Blinding? } \\
\text { Clinical staff }\end{array}$ & Unclear risk & $\begin{array}{l}\text { Not documented, however, this would be difficult due to differences in suture } \\
\text { materials. }\end{array}$ \\
\hline $\begin{array}{l}\text { Blinding? } \\
\text { Outcome assessors }\end{array}$ & Unclear risk & $\begin{array}{l}\text { Not documented, however, this would be difficult due to differences in suture } \\
\text { materials. }\end{array}$ \\
\hline $\begin{array}{l}\text { Incomplete outcome data } \\
\begin{array}{l}\text { addressed? } \\
\text { All outcomes }\end{array}\end{array}$ & Low risk & All participants entered into the trial were included in the analysis. \\
\hline \begin{tabular}{l} 
Free of other bias? \\
\hline
\end{tabular} & Low risk & No baseline imbalance apparent. \\
\hline
\end{tabular}

Saint 1993

\begin{tabular}{ll}
\hline Methods & Randomised trial. \\
\hline Participants & Setting - Princess Anne Wing, Royal United Hospital, Bath, UK. \\
1000 women randomised. \\
Inclusion criteria - women who delivered spontaneously or with assistance with perineal trauma \\
'deemed worthy of repair'. \\
Exclusion criteria - women with third degree tear. \\
Parity - not specified. \\
Mean age - not specified. \\
Operators - midwives and doctors. \\
Method of repair - continuous suture to close posterior vaginal wall, deeper layer were opposed with \\
interrupted stitches and skin closed with interrupted or continuous subcuticular (depending on opera- \\
tor's preference). \\
The actual number of women allocated to each group is not stated.
\end{tabular}


Saint 1993 (Continued)

Intervention group - glycerol-impregnated catgut (Softgut, no details given regarding gauge of suture material or size of needle).

Comparison group - untreated chromic catgut (no details given regarding gauge of suture material or size of needle).

\begin{tabular}{ll} 
Outcomes & Pain at 24 hours; 10 days; 6 weeks; 3 and 6 months postpartum. \\
& Dyspareunia at 3 and 6 months postpartum. \\
\hline Notes & $\begin{array}{l}\text { No description of the groups at trial entry to assess if baseline data were similar. There was also no de- } \\
\text { scription of the actual intervention received. }\end{array}$
\end{tabular}

\section{Risk of bias}

\begin{tabular}{lll}
\hline Bias & Authors' judgement & Support for judgement \\
\hline $\begin{array}{l}\text { Adequate sequence gener- } \\
\text { ation? }\end{array}$ & Unclear risk & 'Randomly allocated.' \\
\hline Allocation concealment? & Unclear risk & Very little information provided on study methods. \\
\hline $\begin{array}{l}\text { Blinding? } \\
\text { Women }\end{array}$ & Unclear risk & Not stated. \\
\hline $\begin{array}{l}\text { Blinding? } \\
\text { Clinical staff }\end{array}$ & Unclear risk & Not stated. \\
\hline $\begin{array}{l}\text { Blinding? } \\
\text { Outcome assessors }\end{array}$ & Unclear risk & Not stated. \\
\hline $\begin{array}{l}\text { Incomplete outcome data } \\
\begin{array}{l}\text { addressed? } \\
\text { All outcomes }\end{array}\end{array}$ & Unclear risk & Loss to follow up was not clear but there was missing data at all data collec- \\
\hline $\begin{array}{l}\text { Free of other bias? } \\
\text { tion points (10 - 15\% missing data). }\end{array}$ \\
\hline
\end{tabular}

Spencer 1986

\begin{tabular}{ll}
\hline Methods & RCT. \\
\hline Participants & Setting - Royal Berkshire Hospital, Reading, UK. \\
& 737 women randomised. \\
& Inclusion criteria - women requiring perineal repair (including episiotomies and lacerations). \\
& Exclusion criteria - not documented. \\
& Parity - primigravida and multigravida. \\
Mean age - intervention group $=26.5 ;$ comparison group $=27.1$. \\
Operators - doctors and supervised medical students.
\end{tabular}

Interventions

Method of repair - continuous suture to repair the vagina and interrupted sutures to oppose the deeper tissues. The perineal skin was closed with either interrupted or subcuticular as preferred by the operators (each operator used the same technique regardless of the material used).

Intervention group - $(n=377)$ glycerol-impregnated catgut (Softgut, gauge 2-0 on a $37 \mathrm{~mm}$ diamond point half circle needle). 
Spencer 1986 (Continued)

Comparison group - $(n=360)$ untreated chromic catgut (gauge 2-0 on a $35 \mathrm{~mm}$ taper cut half circle needle).

\begin{tabular}{ll}
\hline Outcomes & Pain at 10 days and 3 months postpartum. \\
& Removal of suture material at 10 days and 3 months. \\
& Healing by secondary intention and perineal breakdown at 10 days, resuturing by 3 months. \\
& Dyspareunia at 3 months postpartum. \\
\hline Notes & $\begin{array}{l}\text { Data were analysed primarily by allocated suture material group. Secondary analysis based on suture } \\
\text { material actually used and on technique of repair were also performed. }\end{array}$
\end{tabular}

\section{Risk of bias}

\begin{tabular}{|c|c|c|}
\hline Bias & Authors' judgement & Support for judgement \\
\hline $\begin{array}{l}\text { Adequate sequence gener- } \\
\text { ation? }\end{array}$ & Unclear risk & Randomly allocated. \\
\hline Allocation concealment? & Unclear risk & Not stated. \\
\hline $\begin{array}{l}\text { Blinding? } \\
\text { Women }\end{array}$ & Low risk & 'Women were unaware of the allocated suture material.' \\
\hline $\begin{array}{l}\text { Blinding? } \\
\text { Clinical staff }\end{array}$ & Unclear risk & Not stated. \\
\hline $\begin{array}{l}\text { Blinding? } \\
\text { Outcome assessors }\end{array}$ & Low risk & 'Community midwives were unaware of the allocated suture material.' \\
\hline $\begin{array}{l}\text { Incomplete outcome data } \\
\text { addressed? } \\
\text { All outcomes }\end{array}$ & Unclear risk & $89 \%$ response rate at 10 days, $70 \%$ at 3 years. \\
\hline Free of other bias? & Low risk & No baseline imbalance apparent. \\
\hline
\end{tabular}

\section{Upton 2002}

\begin{tabular}{ll}
\hline Methods & RCT. \\
\hline Participants & Setting - King George V Memorial Tertiary Hospital, Sydney, Australia. \\
& 391 women randomised. \\
& Inclusion criteria - women with live singleton birth at $>34$ weeks' gestation with a spontaneous vaginal \\
& birth requiring perineal repair (first or second degree tear or episiotomy - median or mediolateral). \\
& Exclusion criteria - women who had an instrumental delivery; third degree tear or needing repair by \\
& medical officer. \\
& Parity - primigravida and multigravida. \\
& Mean age - intervention group = 29.6; comparison group = 29.5. \\
& Operator - midwives.
\end{tabular}


Upton 2002 (Continued) Interventions
Method of repair - standard closure technique with interlocking suture to close vaginal tissue, interrupted stitching to perineal muscle and continuous subcuticular closure to close the skin. The same suture material was used to close all layers.

Intervention group $(n=194)$ - coated polyglycolic suture material (gauge 2-0 on a $40 \mathrm{~mm}$, half-circle taper needle).

Comparison group ( $n=197$ ) - chromic catgut (gauge 2-0 on a $40 \mathrm{~mm}$, half-circle taper needle).

Perineal pain at day 1 , day 3,6 weeks, 3 and 6 months.
Wound infection at 6 weeks.
Resuturing at 6 weeks.
Intercourse resumption at 6 weeks, 3 and 6 months.
Dyspareunia at 6 weeks, 3 and 6 months.

\section{Notes}

\section{Risk of bias}

\begin{tabular}{lll}
\hline Bias & Authors' judgement & Support for judgement \\
\hline $\begin{array}{l}\text { Adequate sequence gener- } \\
\text { ation? }\end{array}$ & Low risk & Random number generator. \\
\hline Allocation concealment? & Low risk & Sealed, numbered opaque envelopes. \\
\hline $\begin{array}{l}\text { Blinding? } \\
\text { Women }\end{array}$ & Low risk & Described as "blinded". \\
\hline $\begin{array}{l}\text { Blinding? } \\
\text { Clinical staff }\end{array}$ & High risk & Not feasible. Different suture materials. \\
\hline $\begin{array}{l}\text { Blinding? } \\
\text { Outcome assessors }\end{array}$ & High risk & Not feasible. Different suture materials. \\
\hline $\begin{array}{l}\text { Incomplete outcome data } \\
\text { addressed? }\end{array}$ & Unclear risk & $\begin{array}{l}\text { Day } 1 \text { follow up 89\%, day 3 96\%, 81\% at } 6 \text { months. Missing data for some out- } \\
\text { comes. }\end{array}$ \\
\hline $\begin{array}{l}\text { Free of other bias? } \\
\text { il outcomes }\end{array}$ & Unclear risk & $\begin{array}{l}\text { Some baseline imbalance (e.g. there were more primiparous women in the } \\
\text { synthetic suture group (54.6\%) vs 40\% in the catgut group; the authors carried } \\
\text { out further analysis to adjust for this). }\end{array}$ \\
\hline
\end{tabular}

mm: millimetre

RCT: randomised controlled trial

vs: versus

Characteristics of excluded studies [ordered by study ID]

\begin{tabular}{ll}
\hline Study & Reason for exclusion \\
\hline Gaasemyr 1977 & This trial examined a nylon, non-absorbable suture material (supramid).
\end{tabular}




\begin{tabular}{ll}
\hline Study & Reason for exclusion \\
\hline Hemsley 1997 & $\begin{array}{l}\text { Trial registration; it was not clear that the trial took place. We have carried out further searches to } \\
\text { try to locate any publications from this study and have attempted to contact the author but have } \\
\text { had no response. }\end{array}$
\end{tabular}

Ketcham 1994

Not a randomised controlled trial. The methodological quality of the study was poor in that no scientific principles were applied to the randomisation process and therefore, results could be subject to bias.

\section{Marques 2001}

This study was reported in a brief abstract with no clear information on study methods. Results were not reported by randomisation group. We attempted to trace the authors for further information on study methods and results but had no response.

Tompkins 1972

Unable to obtain additional information such as method of randomisation, or results (which were not presented in a suitable form to include in this review).

Uslu 1992

In this 3-arm trial there was a mixture of materials used within arms (e.g. catgut and silk) and different techniques were used in different arms.

\section{DATA AND ANALYSES}

\section{Comparison 1. Synthetic sutures versus catgut}

\begin{tabular}{|c|c|c|c|c|}
\hline Outcome or subgroup title & $\begin{array}{l}\text { No. of } \\
\text { studies }\end{array}$ & $\begin{array}{l}\text { No. of } \\
\text { partici- } \\
\text { pants }\end{array}$ & Statistical method & Effect size \\
\hline $\begin{array}{l}1 \text { Short-term pain: pain at day } 3 \text { or less } \\
\text { (women experiencing any pain) }\end{array}$ & 10 & & Risk Ratio (M-H, Random, 95\% Cl) & Subtotals only \\
\hline 1.1 Standard synthetic & 9 & 4017 & Risk Ratio (M-H, Random, 95\% Cl) & $0.83[0.76,0.90]$ \\
\hline 1.2 Fast absorbing & 1 & 908 & Risk Ratio (M-H, Random, 95\% Cl) & $1.02[0.98,1.06]$ \\
\hline 2 Short-term pain: pain at day 4 - 10 & 4 & & Risk Ratio (M-H, Fixed, 95\% Cl) & Subtotals only \\
\hline 2.1 Standard synthetic & 3 & 2044 & Risk Ratio (M-H, Fixed, 95\% Cl) & $0.78[0.67,0.90]$ \\
\hline 2.2 Fast absorbing & 1 & 846 & Risk Ratio (M-H, Fixed, 95\% Cl) & $1.05[0.94,1.18]$ \\
\hline 3 Analgesia use - up to day 10 & 6 & & Risk Ratio (M-H, Random, 95\% Cl) & Subtotals only \\
\hline 3.1 Standard synthetic & 5 & 2820 & Risk Ratio (M-H, Random, 95\% Cl) & $0.71[0.59,0.87]$ \\
\hline 3.2 Fast absorbing & 1 & 908 & Risk Ratio (M-H, Random, 95\% Cl) & $0.96[0.90,1.01]$ \\
\hline 4 Suture dehiscence (wound breakdown) & 2 & & Risk Ratio (M-H, Fixed, 95\% Cl) & Subtotals only \\
\hline 4.1 Standard synthetic & 1 & 1771 & Risk Ratio (M-H, Fixed, 95\% Cl) & $0.72[0.23,2.25]$ \\
\hline
\end{tabular}




\begin{tabular}{|c|c|c|c|c|}
\hline Outcome or subgroup title & $\begin{array}{l}\text { No. of } \\
\text { studies }\end{array}$ & $\begin{array}{l}\text { No. of } \\
\text { partici- } \\
\text { pants }\end{array}$ & Statistical method & Effect size \\
\hline 4.2 Fast absorbing & 1 & 309 & Risk Ratio (M-H, Fixed, 95\% Cl) & $1.02[0.23,4.48]$ \\
\hline $\begin{array}{l}5 \text { Superficial wound dehiscence, wound } \\
\text { gaping up to day } 10\end{array}$ & 4 & 2219 & Risk Ratio (M-H, Random, 95\% Cl) & $0.58[0.36,0.94]$ \\
\hline 5.1 Standard synthetic & 4 & 2219 & Risk Ratio (M-H, Random, 95\% Cl) & $0.58[0.36,0.94]$ \\
\hline 6 Resuturing of wound - up to 3 months & 4 & 2402 & Risk Ratio (M-H, Fixed, 95\% Cl) & $0.25[0.08,0.74]$ \\
\hline 6.1 Standard synthetic & 4 & 2402 & Risk Ratio (M-H, Fixed, 95\% Cl) & $0.25[0.08,0.74]$ \\
\hline $\begin{array}{l}7 \text { Removal of suture material - up to } 3 \\
\text { months }\end{array}$ & 4 & & Risk Ratio (M-H, Fixed, 95\% Cl) & Subtotals only \\
\hline 7.1 Standard synthetic & 3 & 2520 & Risk Ratio (M-H, Fixed, 95\% Cl) & $1.81[1.46,2.24]$ \\
\hline 7.2 Fast absorbing & 1 & 309 & Risk Ratio (M-H, Fixed, 95\% Cl) & $0.77[0.11,5.37]$ \\
\hline 8 Long-term pain - at 3 months postpartum & 5 & & Risk Ratio (M-H, Fixed, 95\% Cl) & Subtotals only \\
\hline 8.1 Standard synthetic & 4 & 2525 & Risk Ratio (M-H, Fixed, 95\% Cl) & $0.86[0.68,1.09]$ \\
\hline 8.2 Fast absorbing & 2 & 370 & Risk Ratio (M-H, Fixed, 95\% Cl) & $0.80[0.55,1.17]$ \\
\hline 9 Dyspareunia - at 3 months postpartum & 5 & & Risk Ratio (M-H, Random, 95\% Cl) & Subtotals only \\
\hline 9.1 Standard synthetic & 5 & 2506 & Risk Ratio (M-H, Random, 95\% Cl) & $0.93[0.70,1.24]$ \\
\hline 9.2 Fast absorbing & 1 & 61 & Risk Ratio (M-H, Random, 95\% Cl) & $0.57[0.33,0.97]$ \\
\hline
\end{tabular}

Analysis 1.1. Comparison 1 Synthetic sutures versus catgut, Outcome 1 Short-term pain: pain at day 3 or less (women experiencing any pain).

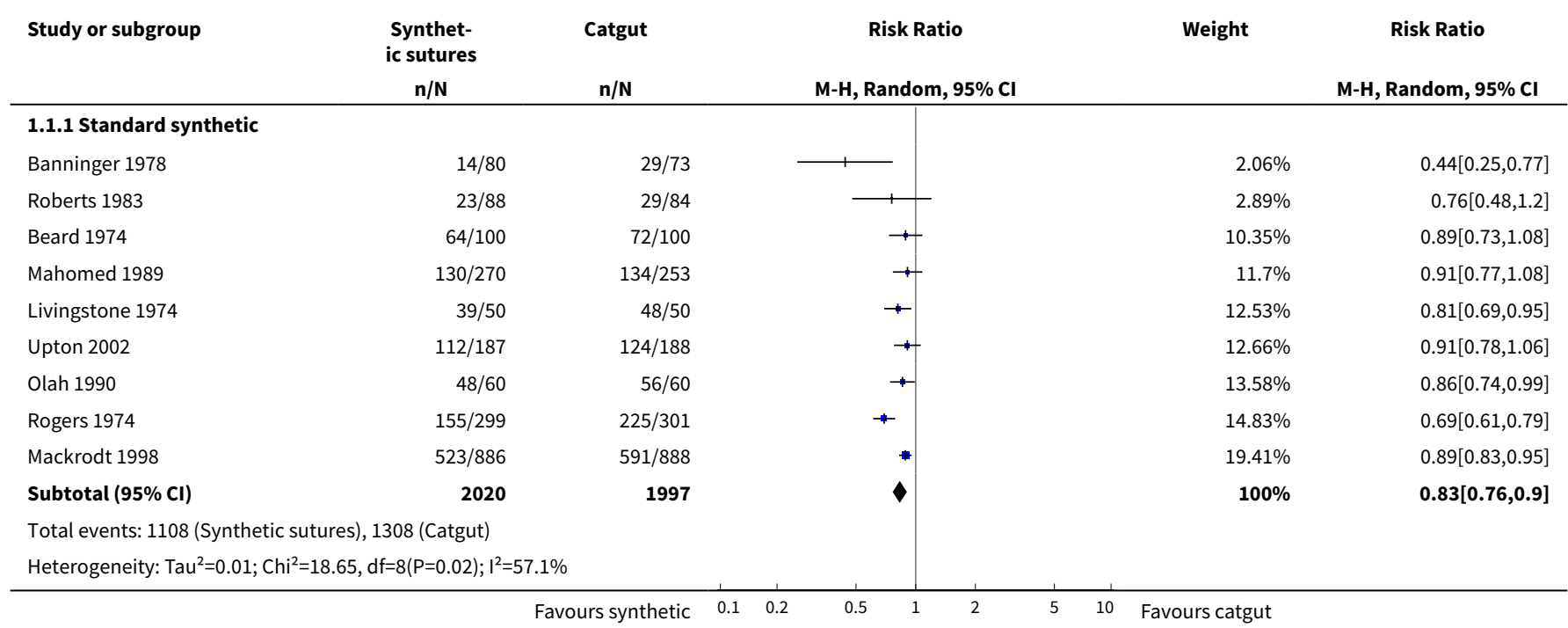




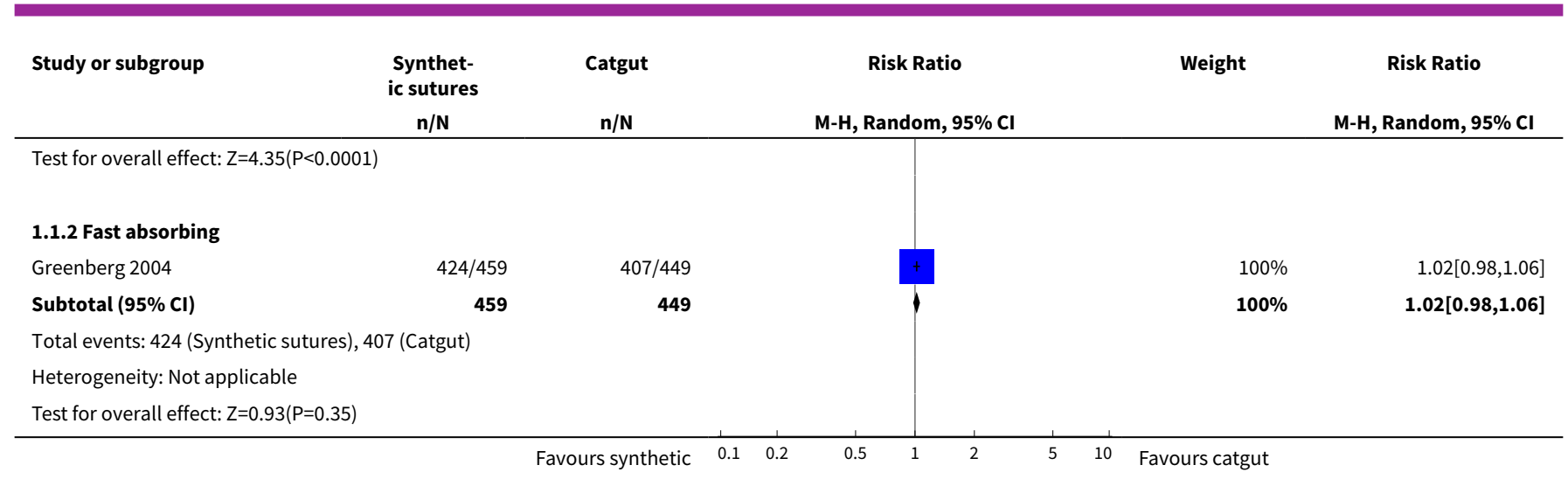

Analysis 1.2. Comparison 1 Synthetic sutures versus catgut, Outcome 2 Short-term pain: pain at day 4 - 10.

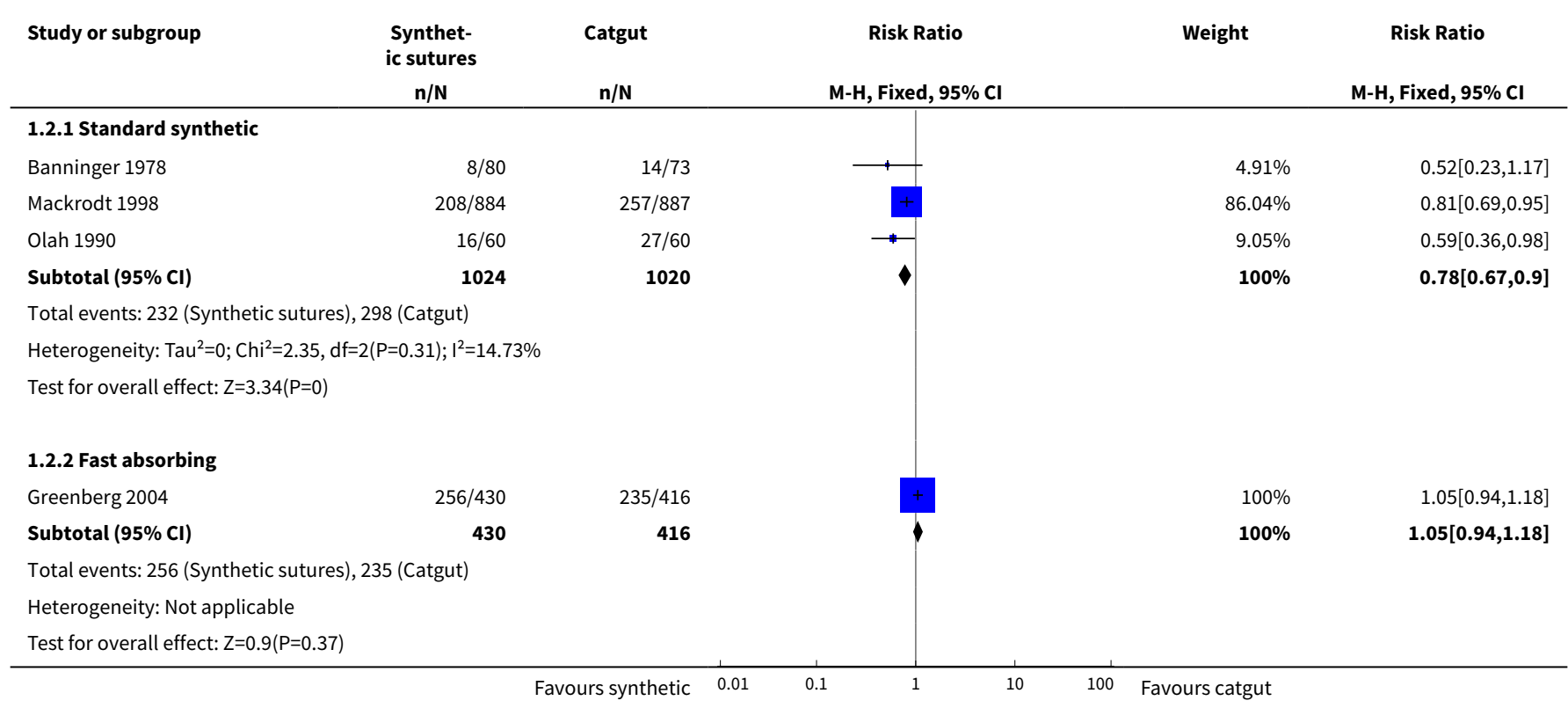

\section{Analysis 1.3. Comparison 1 Synthetic sutures versus catgut, Outcome 3 Analgesia use - up to day 10.}

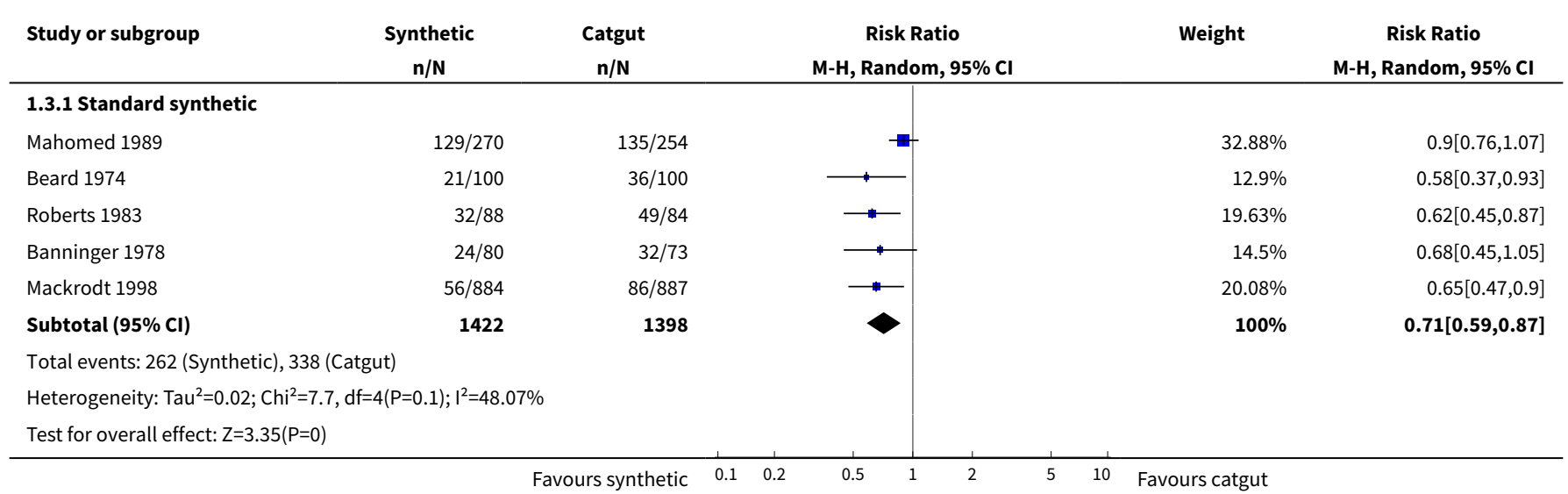




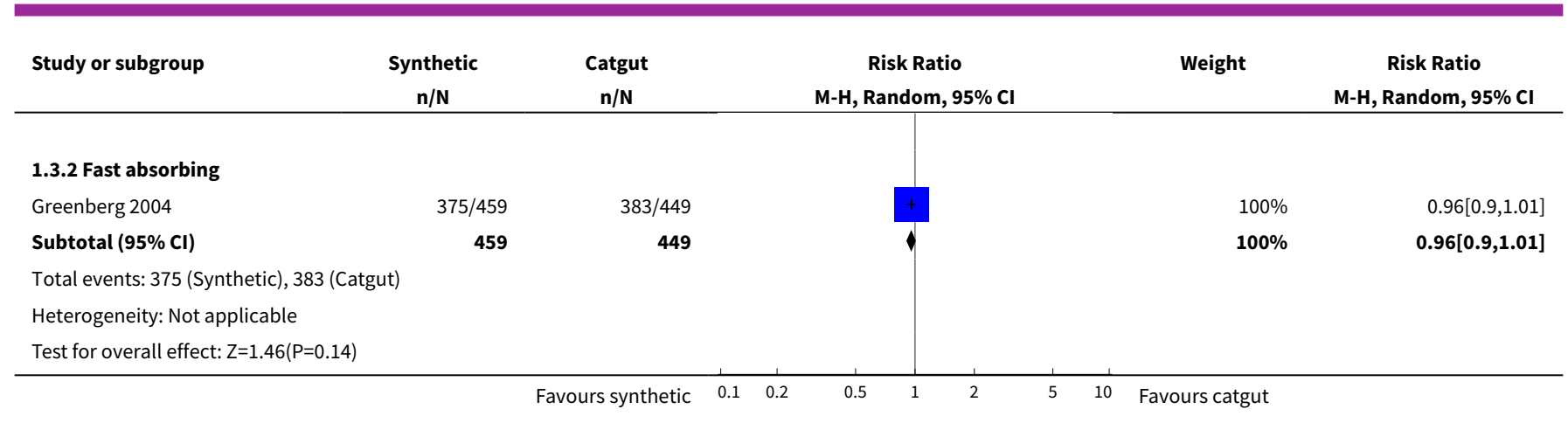

Analysis 1.4. Comparison 1 Synthetic sutures versus catgut, Outcome 4 Suture dehiscence (wound breakdown).

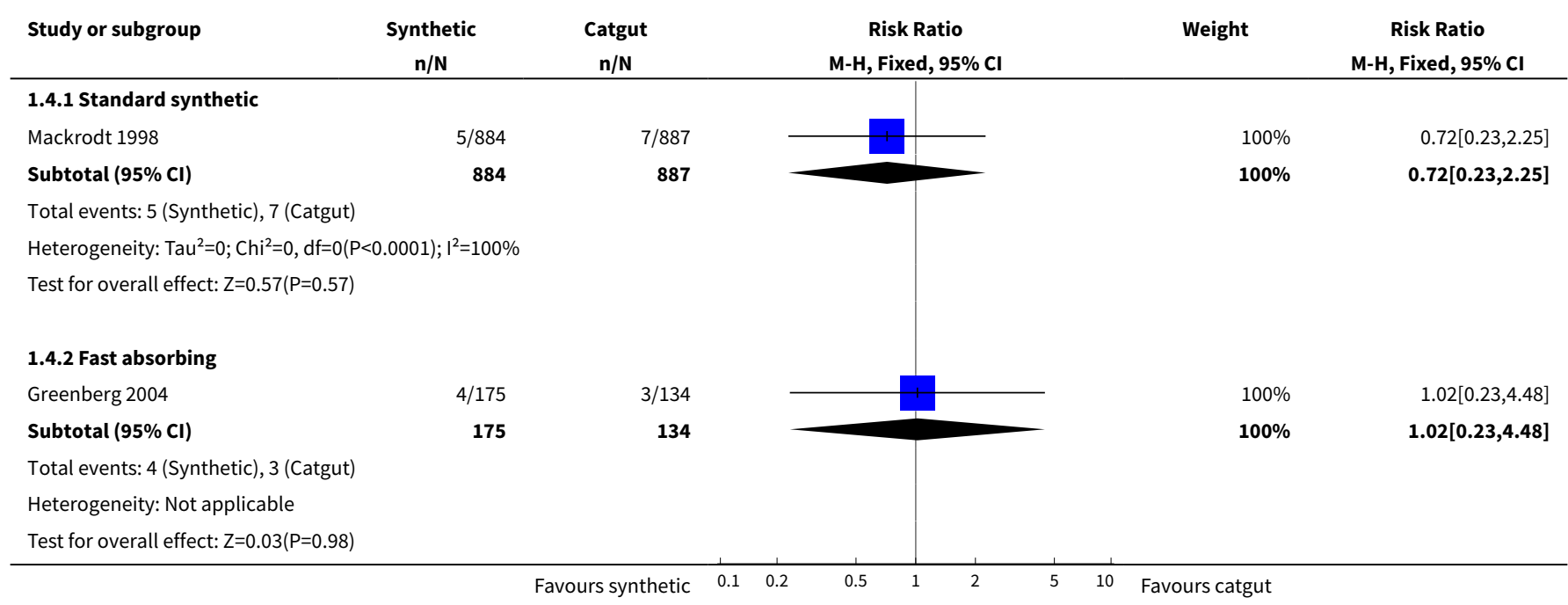

Analysis 1.5. Comparison 1 Synthetic sutures versus catgut, Outcome 5 Superficial wound dehiscence, wound gaping up to day 10.

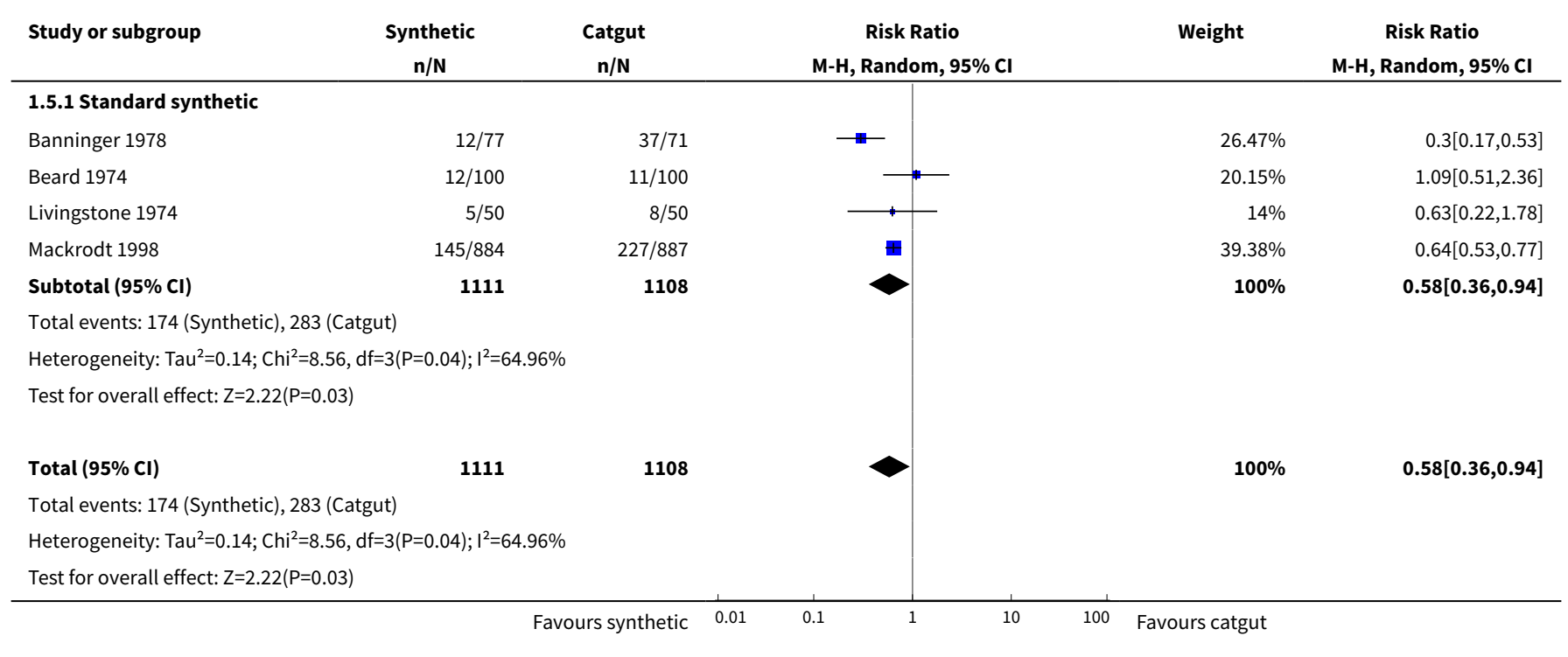


Analysis 1.6. Comparison 1 Synthetic sutures versus catgut, Outcome 6 Resuturing of wound - up to 3 months.

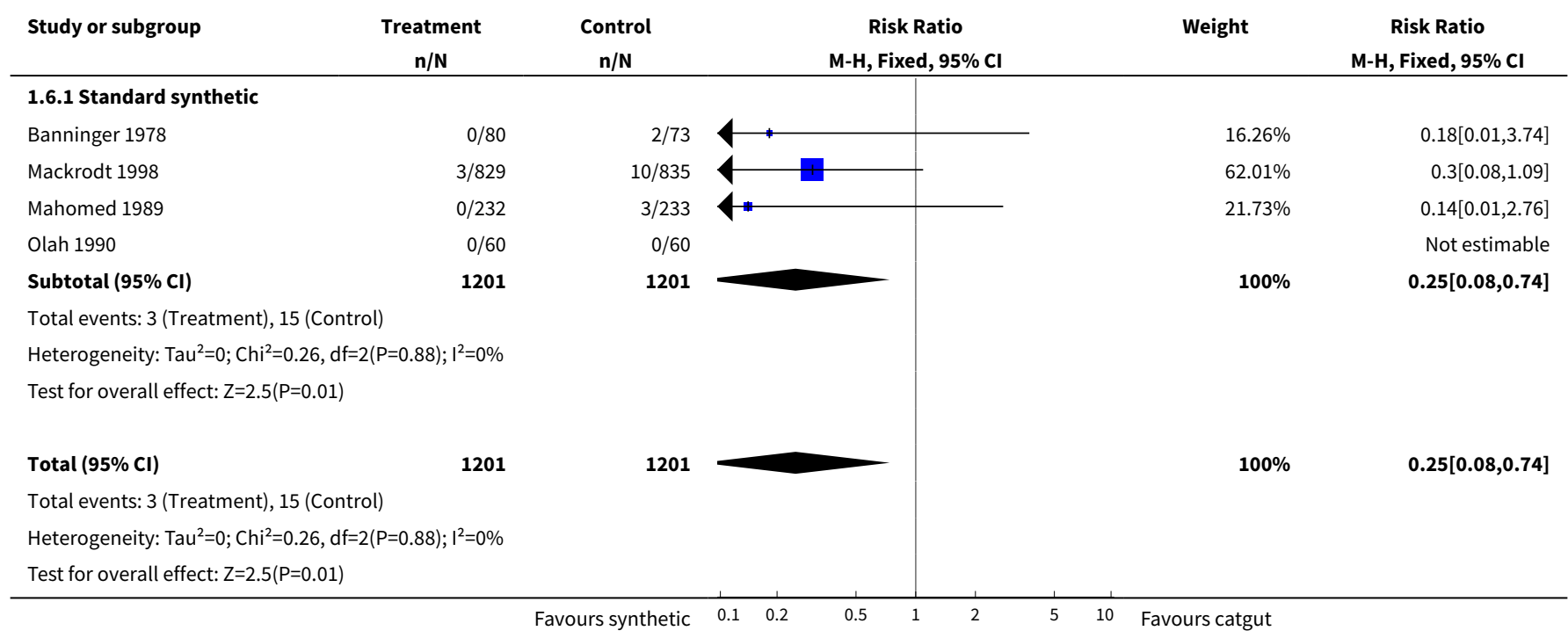

\section{Analysis 1.7. Comparison 1 Synthetic sutures versus catgut, Outcome 7 Removal of suture material - up to 3 months.}

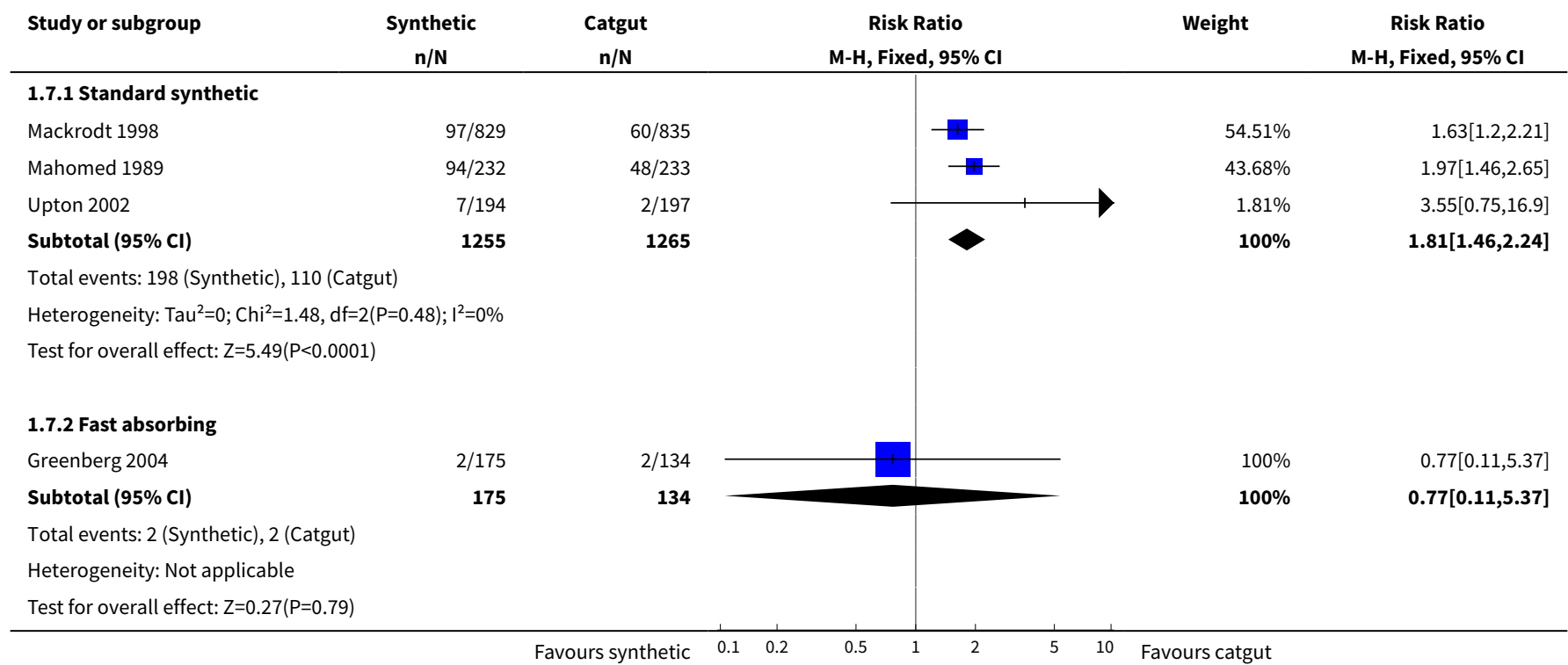

Analysis 1.8. Comparison 1 Synthetic sutures versus catgut, Outcome 8 Long-term pain - at 3 months postpartum.

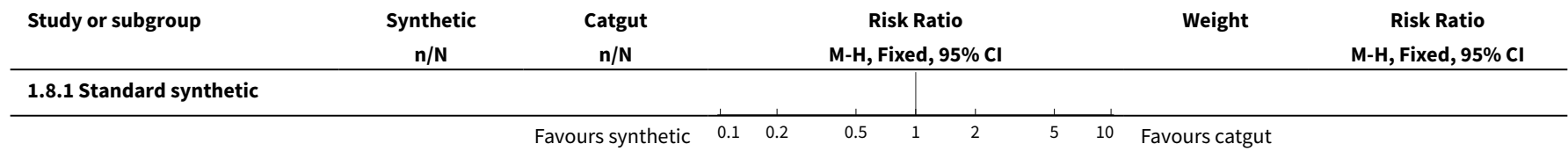




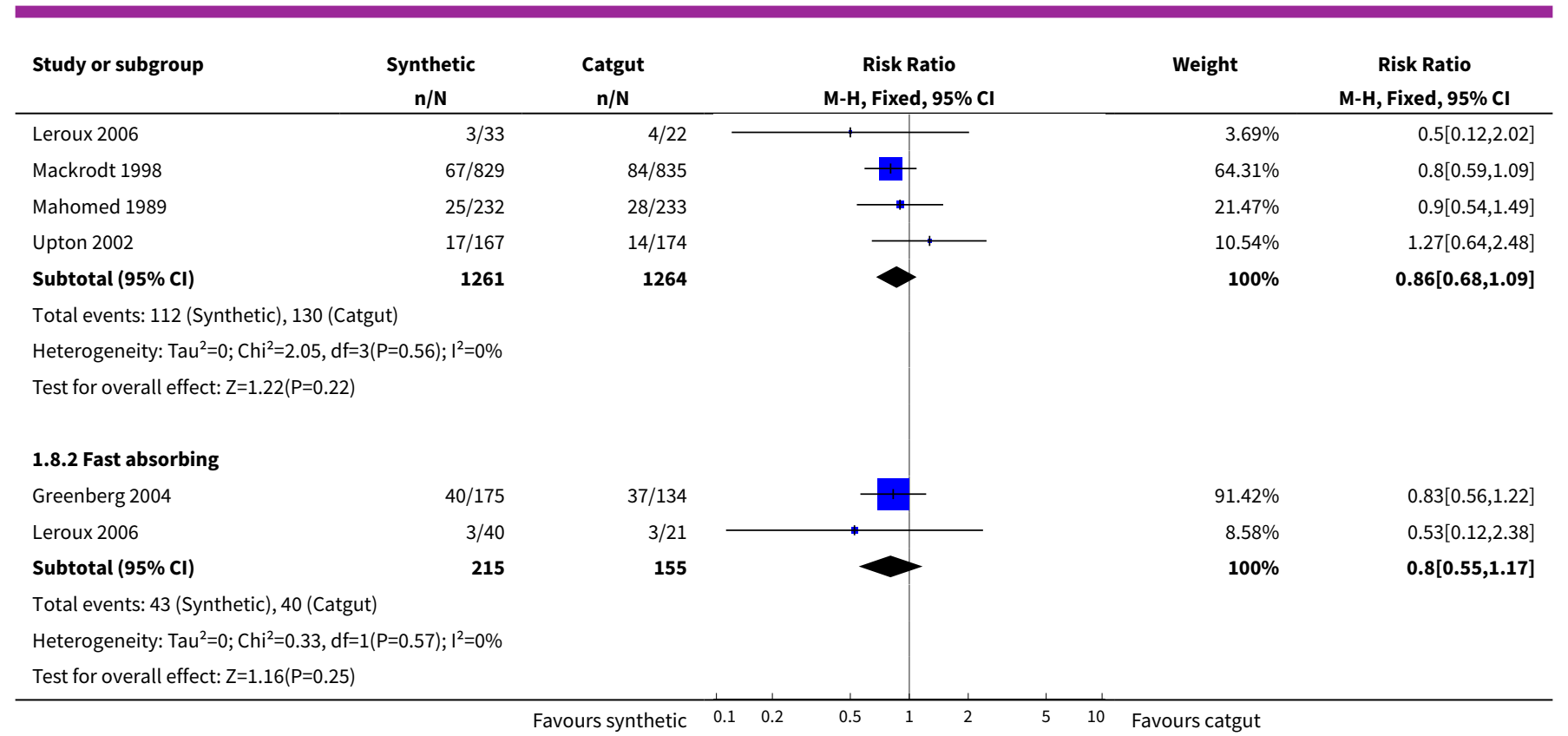

Analysis 1.9. Comparison 1 Synthetic sutures versus catgut, Outcome 9 Dyspareunia - at 3 months postpartum.

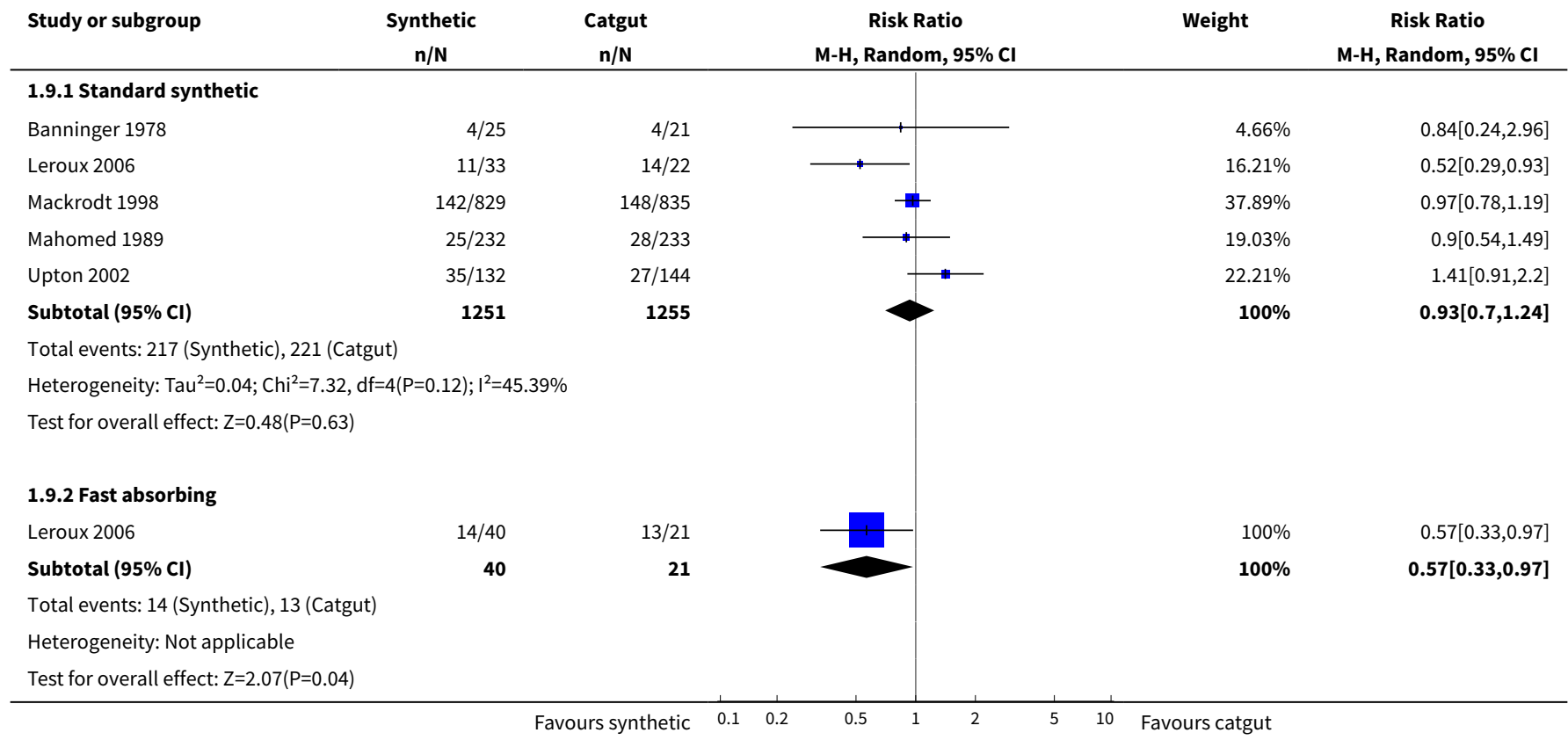

Comparison 2. Fast-absorbing synthetic versus standard absorbable synthetic material

\begin{tabular}{lllll}
\hline Outcome or subgroup title & $\begin{array}{l}\text { No. of } \\
\text { studies }\end{array}$ & $\begin{array}{l}\text { No. of } \\
\text { partici- } \\
\text { pants }\end{array}$ & Statistical method & Effect size \\
\hline 1 Short-term pain: at 3 days or less & 3 & 1968 & Risk Ratio (M-H, Fixed, 95\% Cl) & $1.01[0.92,1.10]$ \\
\hline
\end{tabular}




\begin{tabular}{|c|c|c|c|c|}
\hline Outcome or subgroup title & $\begin{array}{l}\text { No. of } \\
\text { studies }\end{array}$ & $\begin{array}{l}\text { No. of } \\
\text { partici- } \\
\text { pants }\end{array}$ & Statistical method & Effect size \\
\hline 2 Short-term pain: at 10 - 14 days & 2 & 1847 & Risk Ratio (M-H, Fixed, 95\% Cl) & $0.92[0.81,1.03]$ \\
\hline 3 Use of analgesics at 10 days & 1 & 1539 & Risk Ratio (M-H, Fixed, 95\% Cl) & $0.57[0.43,0.77]$ \\
\hline 4 Wound gaping - up to 10 days & 2 & 1659 & Risk Ratio (M-H, Fixed, 95\% Cl) & $1.67[1.07,2.60]$ \\
\hline 5 Resuturing at 3 months postpartum & 1 & 1174 & Risk Ratio (M-H, Fixed, 95\% Cl) & $3.01[0.31,28.86]$ \\
\hline $\begin{array}{l}6 \text { Suture material removed - up to } 3 \\
\text { months }\end{array}$ & 2 & 1847 & Risk Ratio (M-H, Fixed, 95\% Cl) & $0.24[0.15,0.36]$ \\
\hline 7 Long-term pain: pain at 3 months & 2 & 369 & Risk Ratio (M-H, Fixed, 95\% Cl) & $0.79[0.37,1.67]$ \\
\hline 8 Dyspareunia at 3 months & 4 & 1708 & Risk Ratio (M-H, Random, 95\% Cl) & $0.93[0.67,1.29]$ \\
\hline 9 Dyspareunia at 6 - 12 months & 1 & 1325 & Risk Ratio (M-H, Fixed, 95\% Cl) & $0.88[0.68,1.16]$ \\
\hline $\begin{array}{l}10 \text { Maternal satisfaction: satisfied with } \\
\text { repair at } 3 \text { months }\end{array}$ & 1 & 1492 & Risk Ratio (M-H, Fixed, 95\% Cl) & $1.05[0.99,1.10]$ \\
\hline $\begin{array}{l}11 \text { Maternal satisfaction: satisfied with } \\
\text { repair at } 12 \text { months }\end{array}$ & 1 & 1389 & Risk Ratio (M-H, Fixed, 95\% Cl) & $1.02[0.97,1.07]$ \\
\hline
\end{tabular}

Analysis 2.1. Comparison 2 Fast-absorbing synthetic versus standard absorbable synthetic material, Outcome 1 Short-term pain: at 3 days or less.

\begin{tabular}{|c|c|c|c|c|c|}
\hline Study or subgroup & $\begin{array}{c}\text { Fast absorbing } \\
n / N\end{array}$ & $\begin{array}{c}\text { Standard } \\
n / N\end{array}$ & $\begin{array}{c}\text { Risk Ratio } \\
\text { M-H, Fixed, 95\% Cl }\end{array}$ & Weight & $\begin{array}{c}\text { Risk Ratio } \\
\text { M-H, Fixed, } 95 \% \mathrm{Cl} \\
\end{array}$ \\
\hline Gemynthe 1996 & $143 / 155$ & $139 / 153$ & 甲 & $31.73 \%$ & $1.02[0.95,1.09]$ \\
\hline Kettle 2002 & $297 / 770$ & $294 / 770$ & & $66.68 \%$ & $1.01[0.89,1.15]$ \\
\hline Nikolov 2006 & $6 / 60$ & $7 / 60$ & + & $1.59 \%$ & $0.86[0.31,2.4]$ \\
\hline Total $(95 \% \mathrm{CI})$ & 985 & 983 & 1 & $100 \%$ & $1.01[0.92,1.1]$ \\
\hline \multicolumn{6}{|c|}{ Heterogeneity: $\operatorname{Tau}^{2}=0 ; \mathrm{Chi}^{2}=0.13, \mathrm{df}=2(\mathrm{P}=0.94) ; \mathrm{I}^{2}=0 \%$} \\
\hline Test for overall effect & & & & & \\
\hline
\end{tabular}

Analysis 2.2. Comparison 2 Fast-absorbing synthetic versus standard absorbable synthetic material, Outcome 2 Short-term pain: at 10 - 14 days.

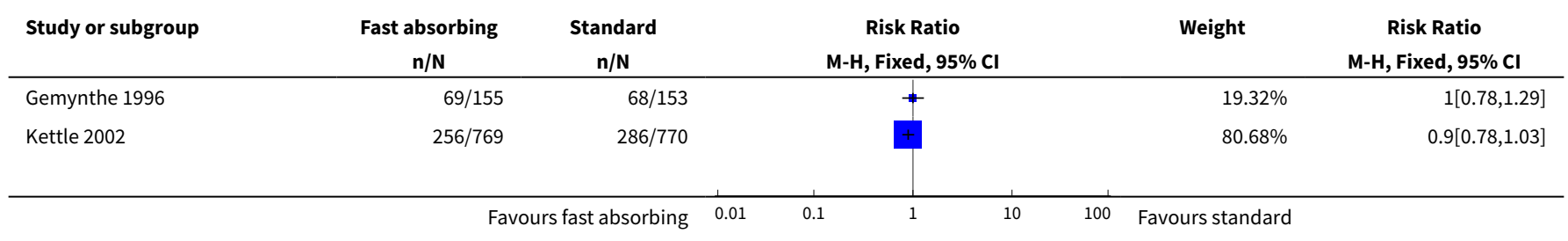




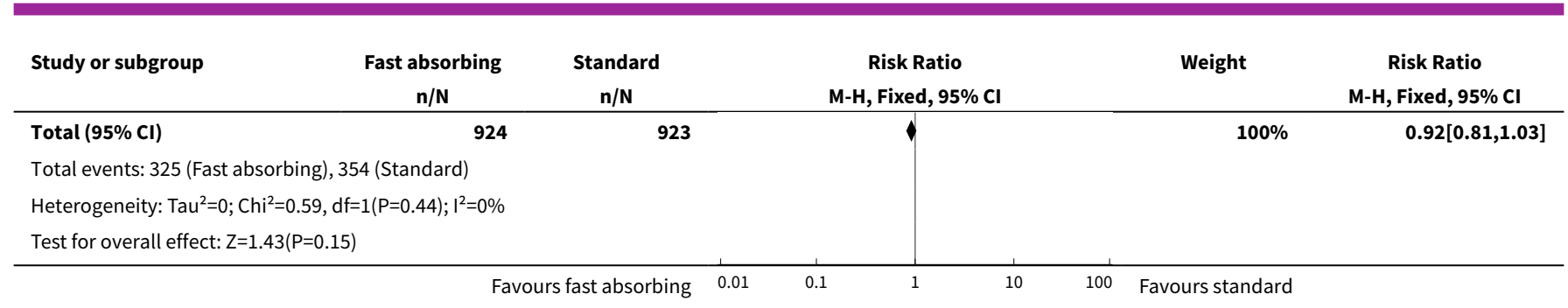

Analysis 2.3. Comparison 2 Fast-absorbing synthetic versus standard absorbable synthetic material, Outcome 3 Use of analgesics at 10 days.

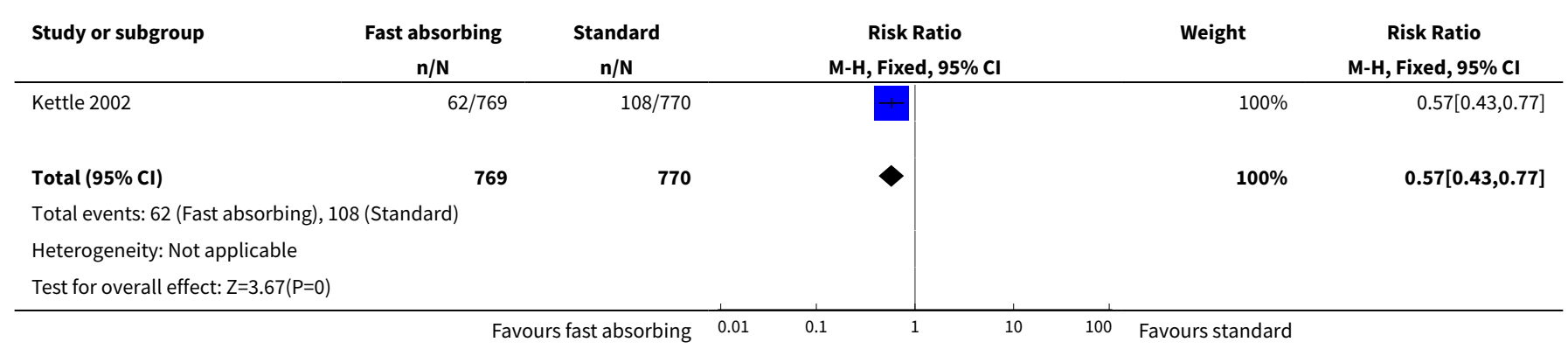

Analysis 2.4. Comparison 2 Fast-absorbing synthetic versus standard absorbable synthetic material, Outcome 4 Wound gaping - up to 10 days.

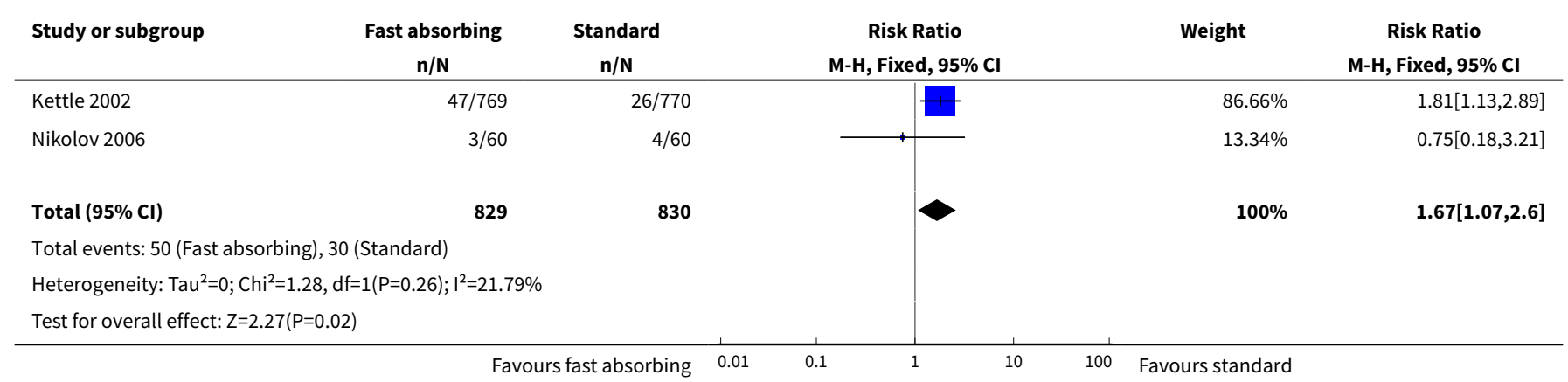

Analysis 2.5. Comparison 2 Fast-absorbing synthetic versus standard absorbable synthetic material, Outcome 5 Resuturing at 3 months postpartum.

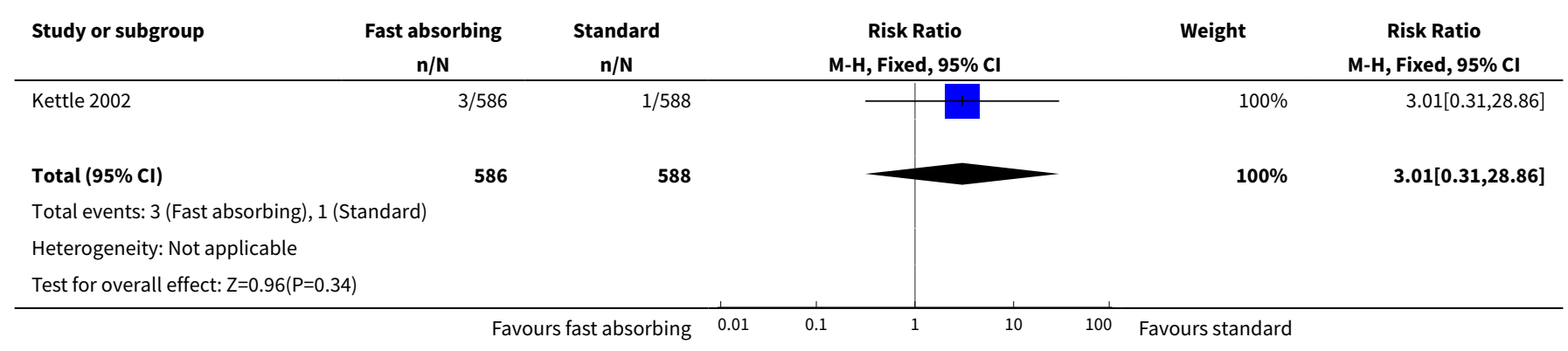


Analysis 2.6. Comparison 2 Fast-absorbing synthetic versus standard absorbable synthetic material, Outcome 6 Suture material removed - up to 3 months.

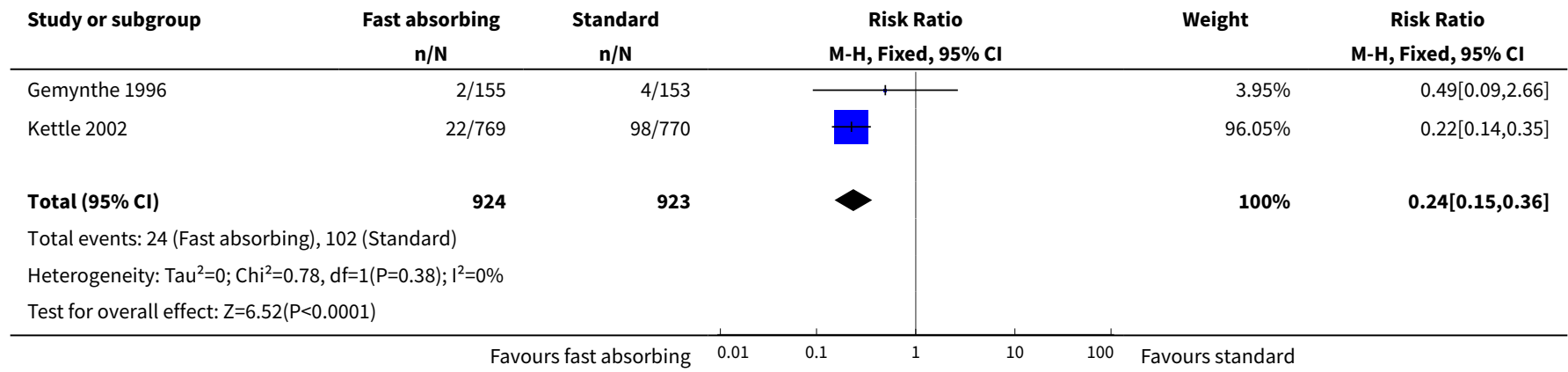

Analysis 2.7. Comparison 2 Fast-absorbing synthetic versus standard absorbable synthetic material, Outcome 7 Long-term pain: pain at 3 months.

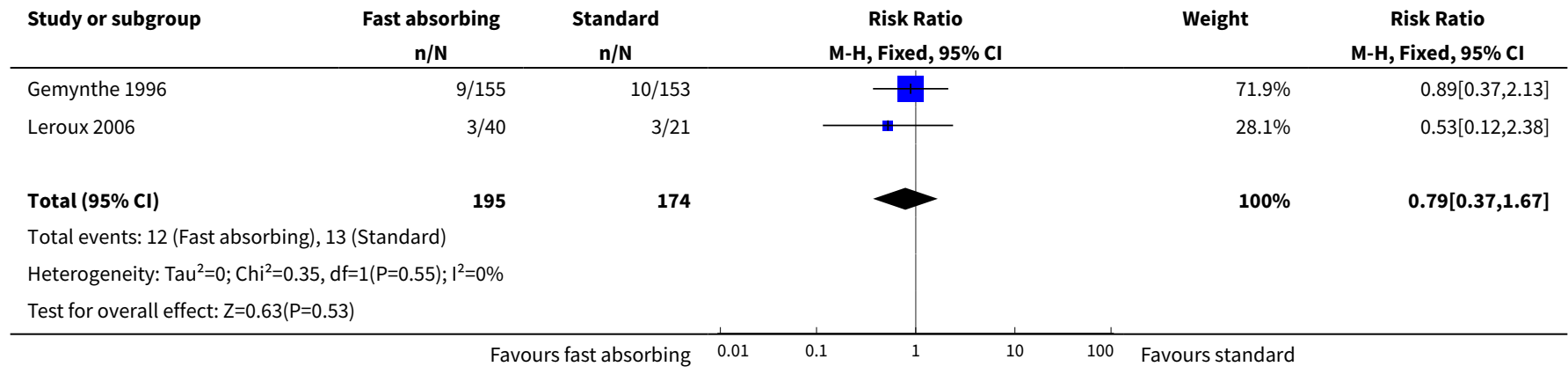

Analysis 2.8. Comparison 2 Fast-absorbing synthetic versus standard absorbable synthetic material, Outcome 8 Dyspareunia at 3 months.

\begin{tabular}{|c|c|c|c|c|c|}
\hline Study or subgroup & $\begin{array}{c}\text { Fast absorbing } \\
n / N\end{array}$ & $\begin{array}{c}\text { Standard } \\
n / N\end{array}$ & $\begin{array}{c}\text { Risk Ratio } \\
\text { M-H, Random, } 95 \% \mathrm{Cl}\end{array}$ & Weight & $\begin{array}{c}\text { Risk Ratio } \\
\text { M-H, Random, } 95 \% \mathrm{Cl}\end{array}$ \\
\hline Gemynthe 1996 & $57 / 155$ & $58 / 153$ & & $35.89 \%$ & $0.97[0.73,1.3]$ \\
\hline Kettle 2002 & $105 / 586$ & $95 / 588$ & & $38.35 \%$ & $1.11[0.86,1.43]$ \\
\hline Leroux 2006 & $14 / 40$ & $11 / 33$ & $\longrightarrow$ & $17.4 \%$ & $1.05[0.55,1.99]$ \\
\hline McElhinney 2000 & $4 / 75$ & $16 / 78$ & $\longrightarrow$ & $8.35 \%$ & $0.26[0.09,0.74]$ \\
\hline \multicolumn{6}{|c|}{ Total events: 180 (Fast absorbing), 180 (Standard) } \\
\hline \multicolumn{6}{|c|}{ Heterogeneity: $\mathrm{Tau}^{2}=0.06 ; \mathrm{Chi}^{2}=7.08, \mathrm{df}=3(\mathrm{P}=0.07) ; \mathrm{I}^{2}=57.64 \%$} \\
\hline \multicolumn{6}{|c|}{ Test for overall effect: $Z=0.44(P=0.66)$} \\
\hline
\end{tabular}


Analysis 2.9. Comparison 2 Fast-absorbing synthetic versus standard absorbable synthetic material, Outcome 9 Dyspareunia at 6 - 12 months.

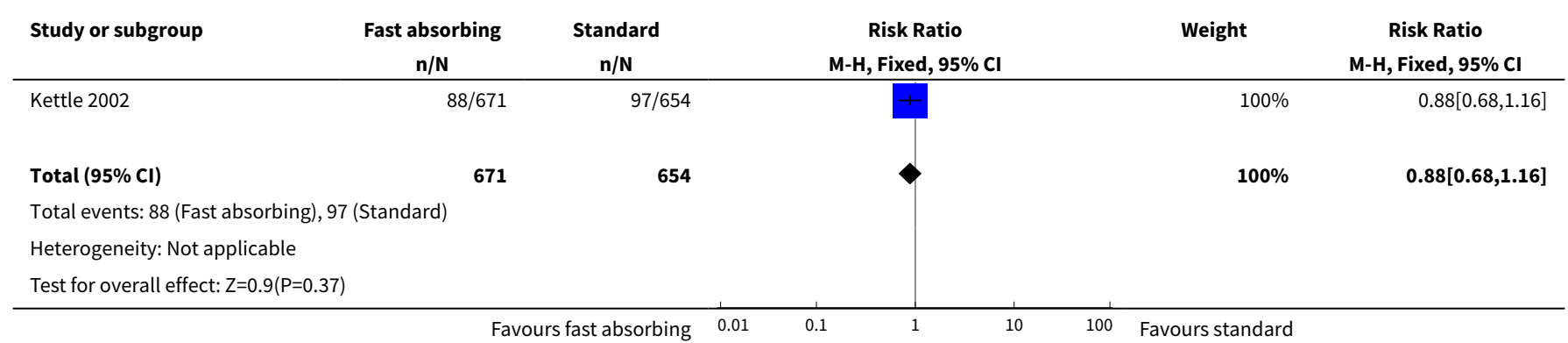

Analysis 2.10. Comparison 2 Fast-absorbing synthetic versus standard absorbable synthetic material, Outcome 10 Maternal satisfaction: satisfied with repair at 3 months.

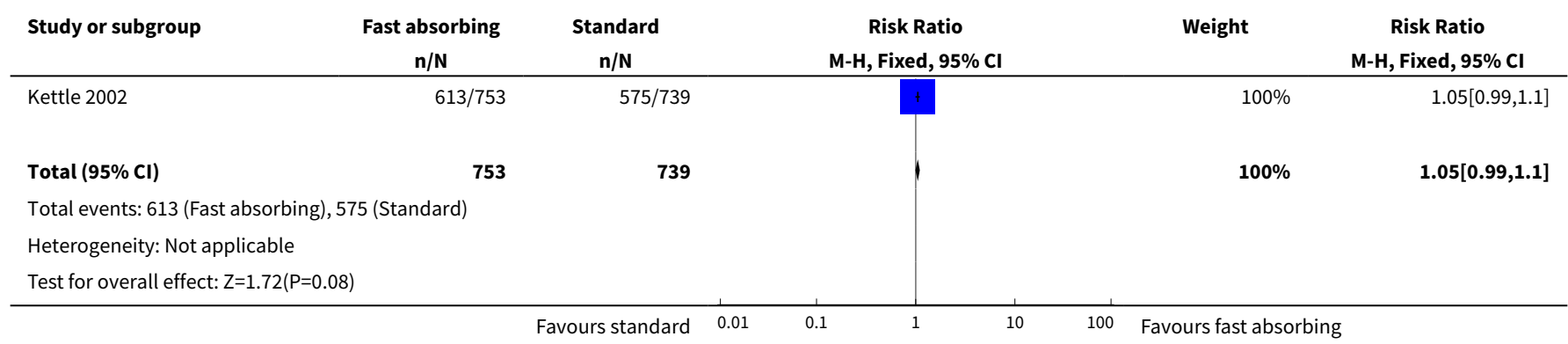

Analysis 2.11. Comparison 2 Fast-absorbing synthetic versus standard absorbable synthetic material, Outcome 11 Maternal satisfaction: satisfied with repair at 12 months.

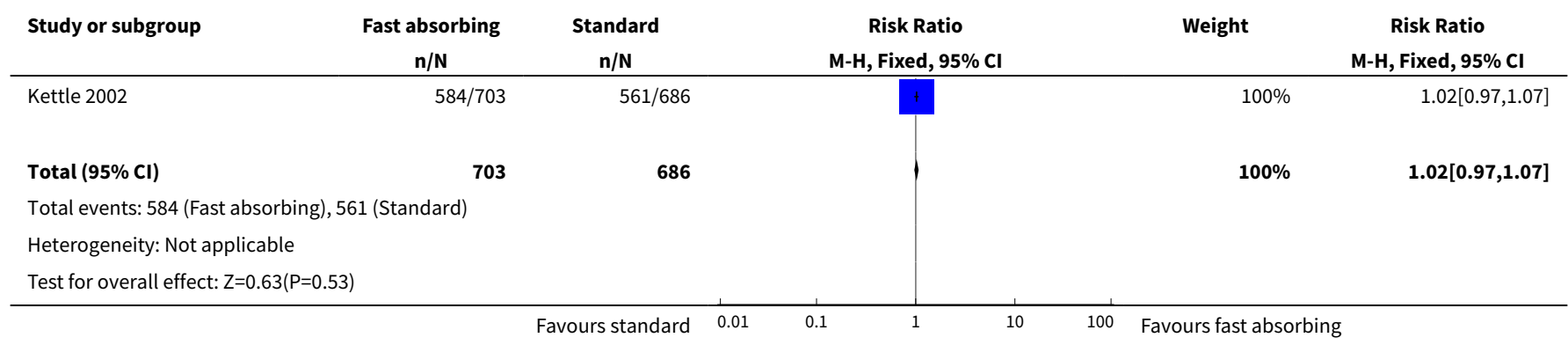

Comparison 3. Glycerol impregnated catgut (softgut) versus chromic catgut

\begin{tabular}{lllll}
\hline Outcome or subgroup title & $\begin{array}{l}\text { No. of } \\
\text { studies }\end{array}$ & $\begin{array}{l}\text { No. of } \\
\text { partici- } \\
\text { pants }\end{array}$ & Statistical method & Effect size \\
\hline $\begin{array}{l}1 \text { Short-term pain: pain at 3 days or } \\
\text { less }\end{array}$ & 1 & 836 & Risk Ratio (M-H, Fixed, 95\% Cl) & $0.99[0.94,1.04]$ \\
\hline
\end{tabular}




\begin{tabular}{lllll}
\hline Outcome or subgroup title & $\begin{array}{l}\text { No. of } \\
\text { studies }\end{array}$ & $\begin{array}{l}\text { No. of } \\
\text { partici- } \\
\text { pants }\end{array}$ & Statistical method & Effect size \\
\hline 2 Short-term pain: pain at 10 - 14 days & 2 & 1541 & Risk Ratio (M-H, Random, 95\% Cl) & $1.15[0.85,1.56]$ \\
\hline 3 Analgesia at day 10 & 1 & 737 & Risk Ratio (M-H, Fixed, 95\% Cl) & $1.91[0.78,4.68]$ \\
\hline 4 Wound dehiscence at 10 days & 1 & 737 & Risk Ratio (M-H, Fixed, 95\% Cl) & $1.75[0.65,4.68]$ \\
\hline 5 Suture removal by 3 months & 1 & 655 & Risk Ratio (M-H, Fixed, 95\% Cl) & $0.42[0.27,0.67]$ \\
\hline 6 Long-term pain: pain at 3 months & 2 & 1639 & Risk Ratio (M-H, Fixed, 95\% Cl) & $1.13[0.78,1.64]$ \\
\hline 7 Dyspareunia at 3 months & 2 & 1473 & Risk Ratio (M-H, Random, 95\% Cl) & $1.16[0.92,1.46]$ \\
\hline 8 Dyspareunia at 6 - 12 months & 1 & 917 & Risk Ratio (M-H, Fixed, 95\% Cl) & $0.96[0.70,1.33]$ \\
\hline
\end{tabular}

Analysis 3.1. Comparison 3 Glycerol impregnated catgut (softgut) versus chromic catgut, Outcome 1 Short-term pain: pain at 3 days or less.

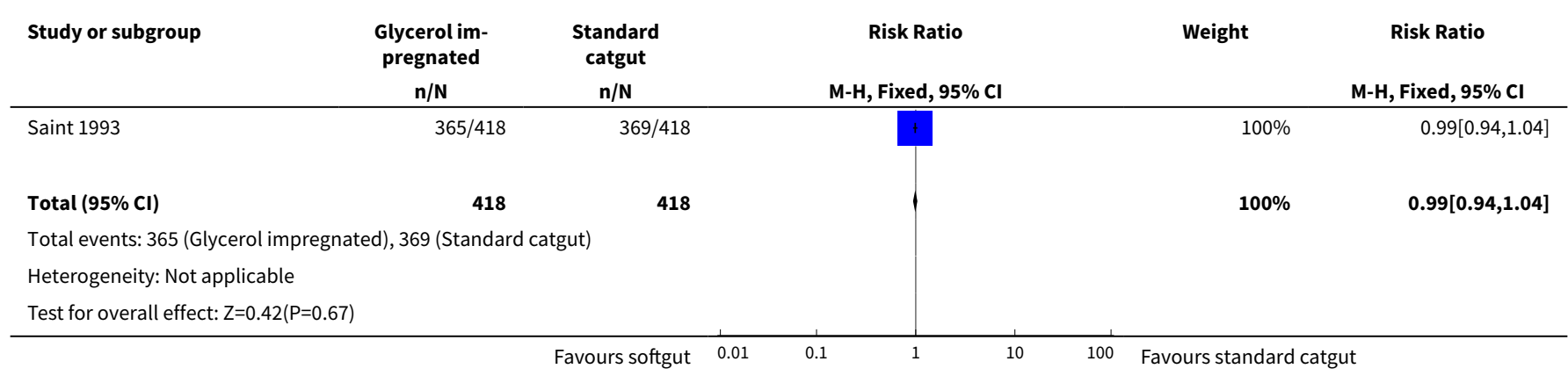

Analysis 3.2. Comparison 3 Glycerol impregnated catgut (softgut) versus chromic catgut, Outcome 2 Short-term pain: pain at 10 - 14 days.

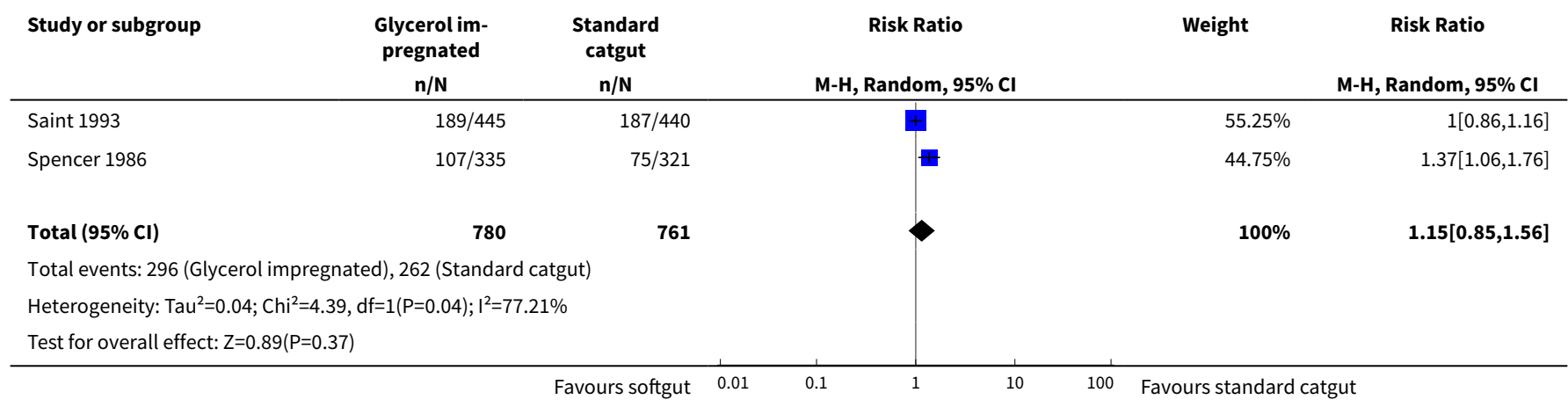


Analysis 3.3. Comparison 3 Glycerol impregnated catgut (softgut) versus chromic catgut, Outcome 3 Analgesia at day 10.

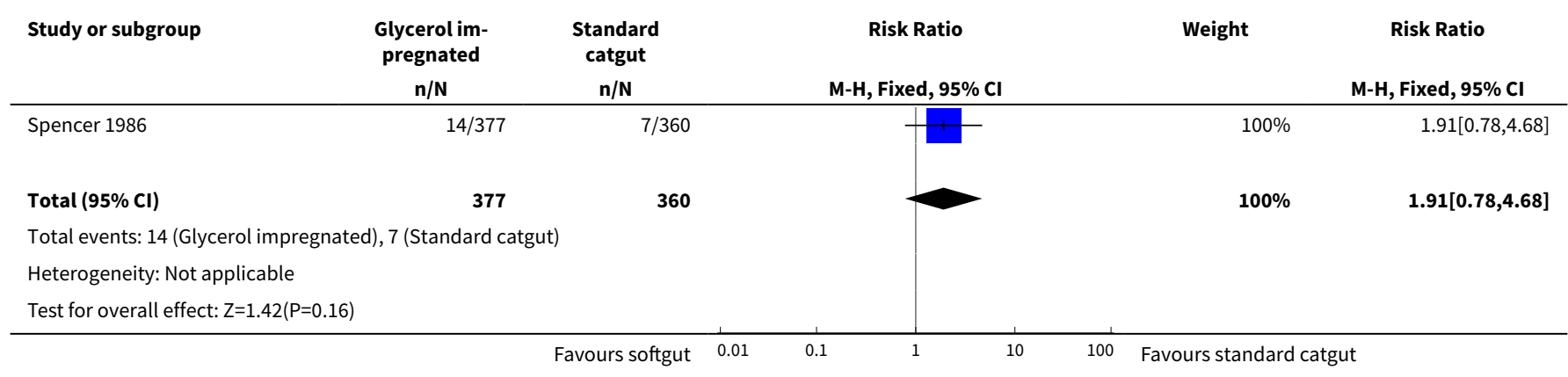

Analysis 3.4. Comparison 3 Glycerol impregnated catgut (softgut) versus chromic catgut, Outcome 4 Wound dehiscence at 10 days.

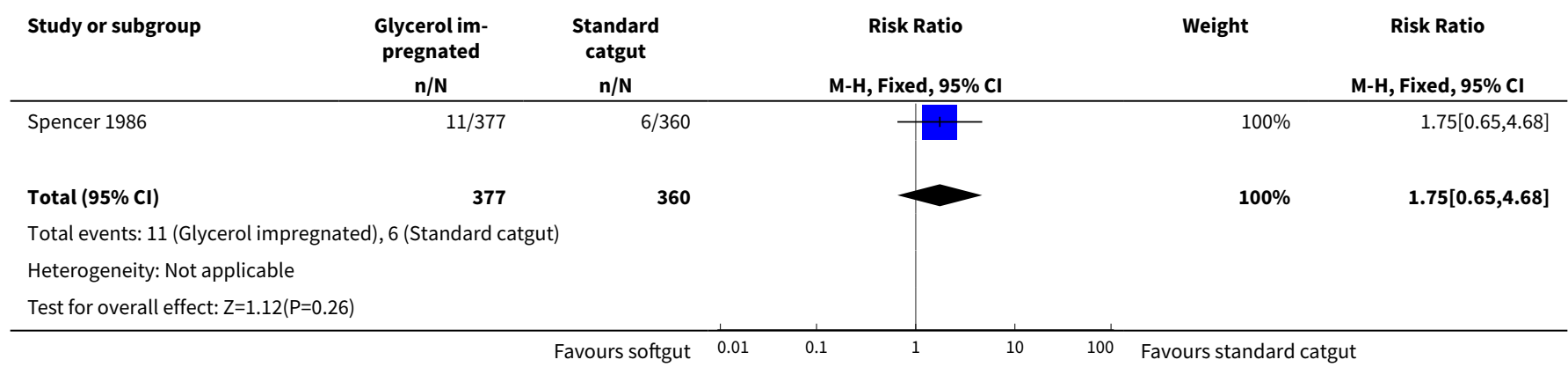

Analysis 3.5. Comparison 3 Glycerol impregnated catgut (softgut) versus chromic catgut, Outcome 5 Suture removal by 3 months.

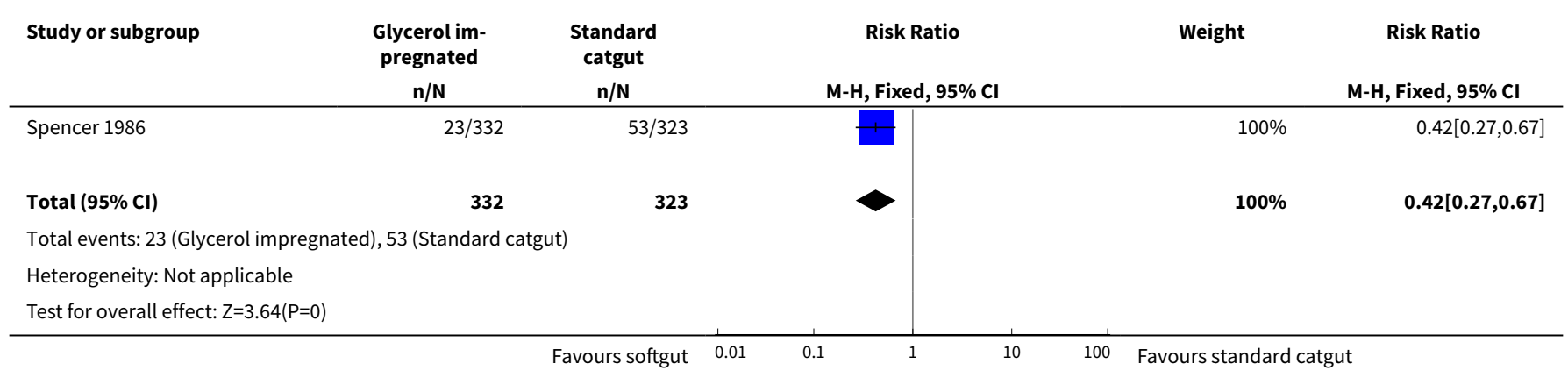


Analysis 3.6. Comparison 3 Glycerol impregnated catgut (softgut) versus chromic catgut, Outcome 6 Long-term pain: pain at 3 months.

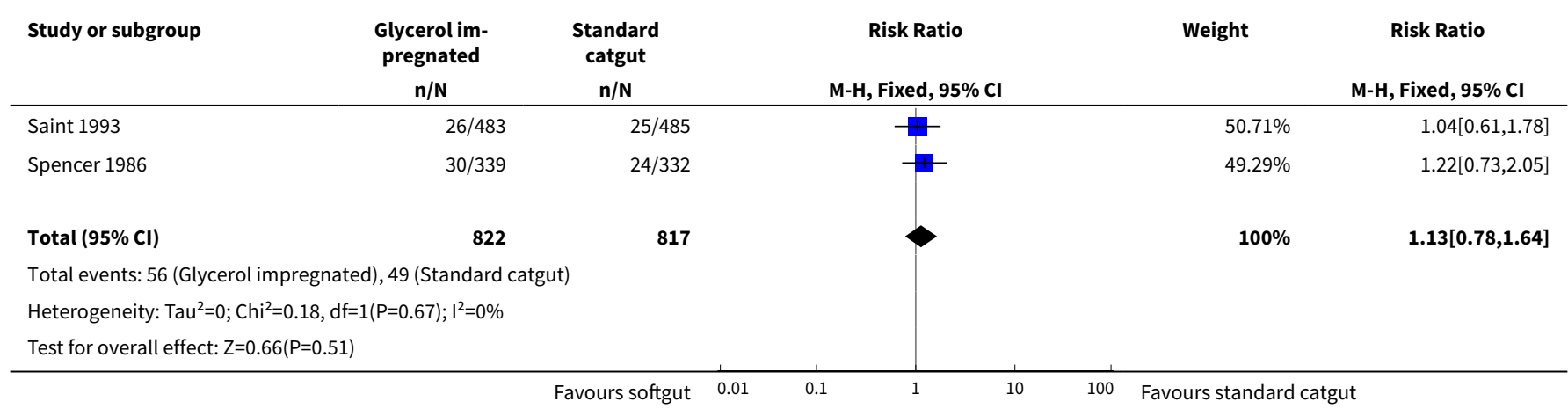

\section{Analysis 3.7. Comparison 3 Glycerol impregnated catgut (softgut) versus chromic catgut, Outcome 7 Dyspareunia at 3 months.}

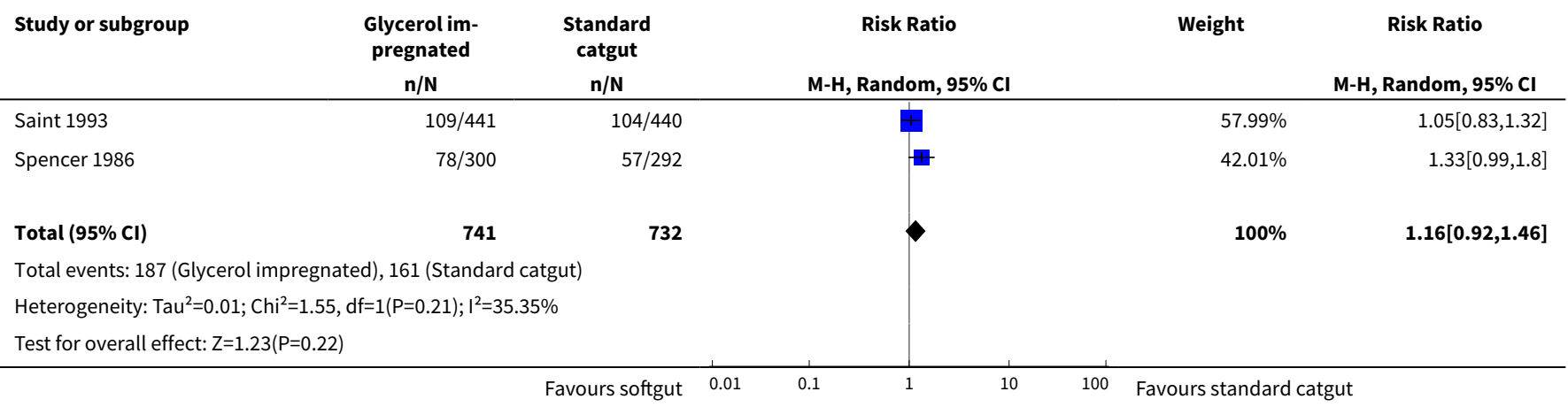

\section{Analysis 3.8. Comparison 3 Glycerol impregnated catgut (softgut)} versus chromic catgut, Outcome 8 Dyspareunia at 6 - 12 months.

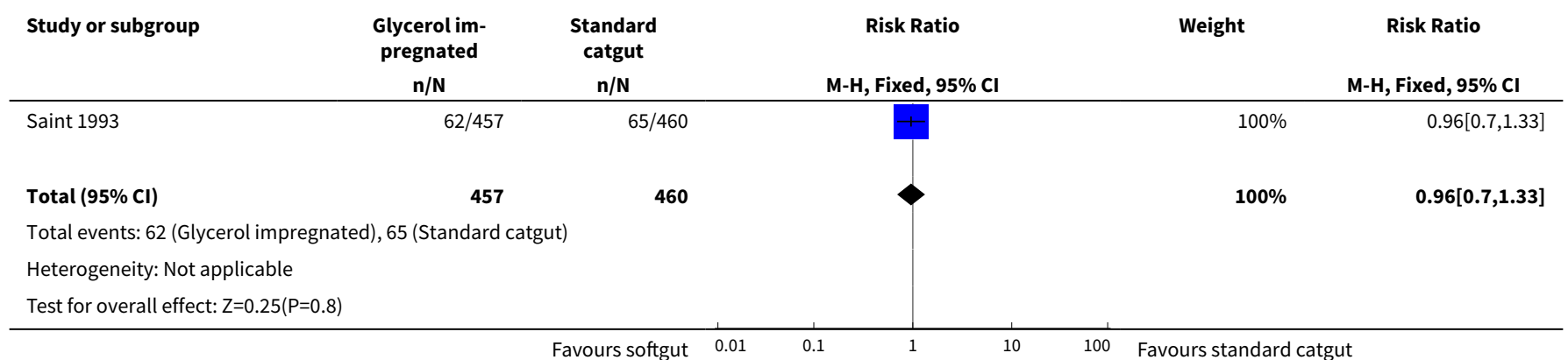


Comparison 4. Monofilament versus standard polyglycolic sutures

\begin{tabular}{|c|c|c|c|c|}
\hline Outcome or subgroup title & $\begin{array}{l}\text { No. of } \\
\text { studies }\end{array}$ & $\begin{array}{l}\text { No. of } \\
\text { partici- } \\
\text { pants }\end{array}$ & Statistical method & Effect size \\
\hline 1 Short-term pain: mean pain scores at 3 days & 1 & 1042 & $\begin{array}{l}\text { Mean Difference (IV, Fixed, 95\% } \\
\mathrm{CI})\end{array}$ & $\begin{array}{l}0.10[-0.12 \\
0.32]\end{array}$ \\
\hline $\begin{array}{l}2 \text { Long-term pain: pain score greater than } 2 \text { at } 8 \text { - } 12 \\
\text { weeks }\end{array}$ & 1 & 705 & Risk Ratio (M-H, Fixed, 95\% Cl) & $\begin{array}{l}1.40[1.01 \\
1.95]\end{array}$ \\
\hline 3 Long-term pain: mean pain scores at $8-12$ weeks & 1 & 705 & $\begin{array}{l}\text { Mean Difference (IV, Fixed, 95\% } \\
\mathrm{Cl})\end{array}$ & $\begin{array}{l}0.22[0.01 \\
0.43]\end{array}$ \\
\hline $\begin{array}{l}4 \text { Wound problems at } 8 \text { - } 12 \text { weeks: women seeking } \\
\text { professional help for problem with perineal repair }\end{array}$ & 1 & 727 & Risk Ratio (M-H, Fixed, 95\% Cl) & $\begin{array}{l}2.42[1.43, \\
4.11]\end{array}$ \\
\hline
\end{tabular}

Analysis 4.1. Comparison 4 Monofilament versus standard polyglycolic sutures, Outcome 1 Short-term pain: mean pain scores at 3 days.

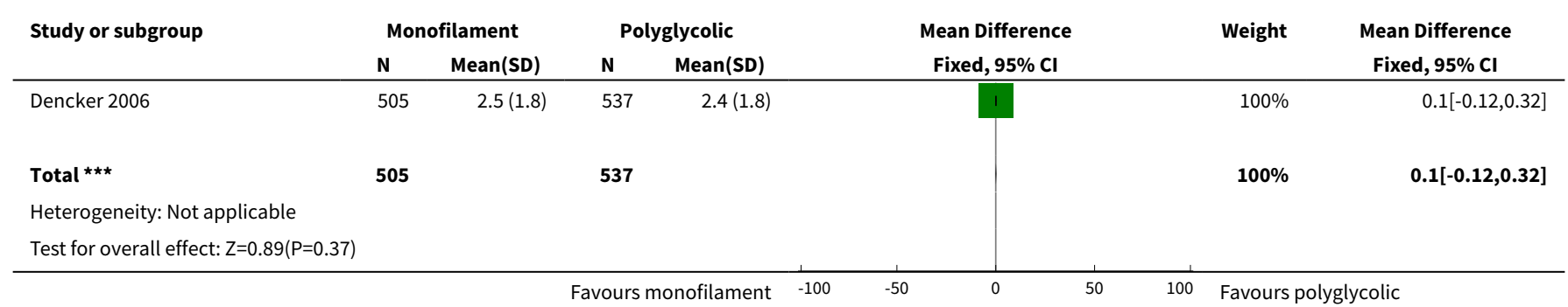

Analysis 4.2. Comparison 4 Monofilament versus standard polyglycolic sutures, Outcome 2 Long-term pain: pain score greater than 2 at 8 - 12 weeks.

\begin{tabular}{|c|c|c|c|c|c|}
\hline Study or subgroup & $\begin{array}{c}\text { Monofilament } \\
\mathrm{n} / \mathrm{N}\end{array}$ & $\begin{array}{c}\text { Polyglycolic } \\
n / N\end{array}$ & $\begin{array}{c}\text { Risk Ratio } \\
\text { M-H, Fixed, 95\% Cl }\end{array}$ & Weight & $\begin{array}{c}\text { Risk Ratio } \\
\text { M-H, Fixed, } 95 \% \mathrm{Cl}\end{array}$ \\
\hline Dencker 2006 & $72 / 357$ & $50 / 348$ & & $100 \%$ & $1.4[1.01,1.95]$ \\
\hline Total $(95 \% \mathrm{CI})$ & 357 & 348 & & $100 \%$ & $1.4[1.01,1.95]$ \\
\hline \multicolumn{6}{|c|}{ Total events: 72 (Monofilament), 50 (Polyglycolic) } \\
\hline \multicolumn{6}{|c|}{ Heterogeneity: Not applicable } \\
\hline
\end{tabular}


Analysis 4.3. Comparison 4 Monofilament versus standard polyglycolic sutures, Outcome 3 Long-term pain: mean pain scores at 8 - 12 weeks.

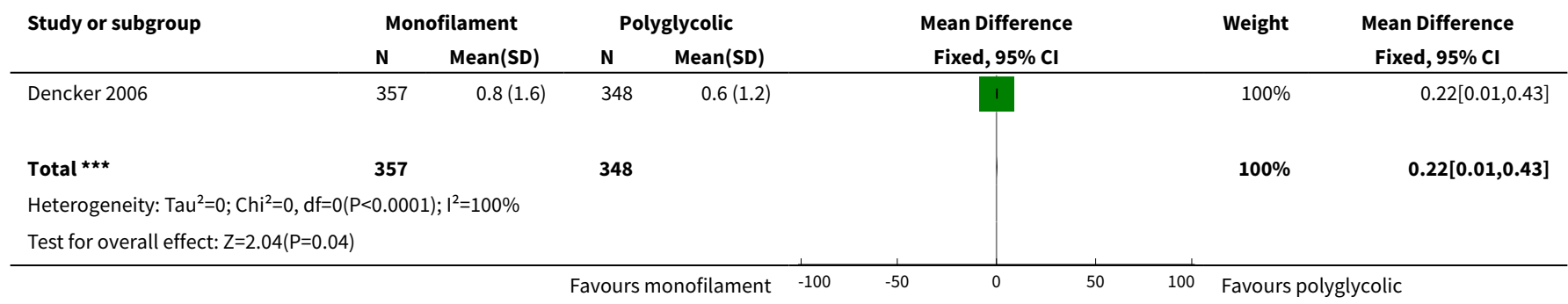

\section{Analysis 4.4. Comparison 4 Monofilament versus standard polyglycolic sutures, Outcome 4 Wound problems at 8 - 12 weeks: women seeking professional help for problem with perineal repair.}

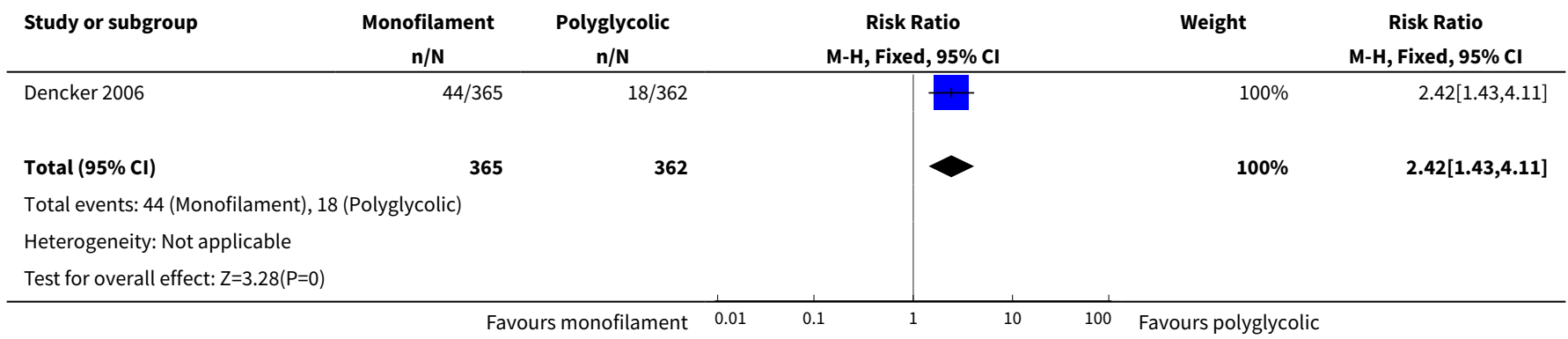

\section{A P P E N D I CES}

\section{Appendix 1. Methods used in earlier versions of the review}

The trials were assessed according to the following four main criteria:

1. adequate concealment of treatment allocation (e.g. opaque sealed numbered envelopes);

2. method of allocation to treatment (e.g. by computer randomisation, random number tables or by quasi-randomisation methods such as alternation or medical record numbers);

3. adequate documentation of how exclusions were handled after treatment allocation - to facilitate intention to treat analysis;

4. adequate blinding of outcome assessment.

Letters were used to indicate the quality of the included trials, for example A was used to indicate a trial which has a high level of quality in which all the criteria were met; B was used to indicate that one or more criteria were partially met or if it is unclear if all the criteria were met and $C$ was used if one or more criteria were not met (Mulrow 1997). We independently assessed the methodological quality of each individual trial and collected details of method of treatment allocation, randomisation, blinding of outcome assessment, handling of exclusions and whether an intention to treat analysis was performed. If any of the above data were not available in the publication or if it was unclear if the criteria were met, it was planned that additional information would be sought from the trialists. However, no additional information was obtained. Included trial data were processed as described by Chalmers et al (Chalmers 1989).

Data were entered directly from the published reports into the Review Manager software (RevMan) and the second reviewer (Richard Johanson) checked the accuracy of the entered data. Where data were not presented in a suitable format for data entry, or if data were missing, additional information was sought from the trialists by personal communication in the form of a letter or telephone call. The subset of data for the Mahomed and Grant trial (Mahomed 1989) was obtained by Professor Adrian Grant for the Pre-Cochrane review in 1993 and is presented in a similar format in 'Effective Care in Pregnancy and Childbirth' (Grant 1989). Missing data from the Olah (Olah 1990) trial were obtained in witting from Karl Olah indirectly via Professor Grant. 
Statistical analysis was undertaken using the RevMan software for calculation of the treatment effect as represented by the odds ratio, proportional and absolute risk reductions.

Analysis was performed using the Peto method for odds ratio.

A sensitivity analysis was performed and it was reassuring to find that the treatment effect still held when the poorer quality trials were excluded.

\section{WHAT'S NEW}

\begin{tabular}{|c|c|c|}
\hline Date & Event & Description \\
\hline 9 November 2009 & New search has been performed & $\begin{array}{l}\text { Search updated. In addition to the eight studies included in pre- } \\
\text { vious versions of the review, we have included } 10 \text { new stud- } \\
\text { ies (Dencker 2006; Gemynthe 1996; Greenberg 2004; Kettle } \\
\text { 2002; Leroux 2006; McElhinney 2000; Nikolov 2006; Saint 1993; } \\
\text { Spencer 1986; Upton 2002). We have excluded another four stud- } \\
\text { ies (Gaasemyr 1977; Hemsley 1997; Marques 2001; Uslu 1992). } \\
\text { The updated review uses updated methods, examines a broader } \\
\text { range of suture materials (including fast-absorbing synthetic ma- } \\
\text { terials) and includes results for new comparisons. }\end{array}$ \\
\hline
\end{tabular}

9 November $2009 \quad$ New citation required and conclusions

There is new evidence on synthetic suture materials; rapidly absorbing materials may reduce the need for suture removal.

\section{H I S T O R Y}

Protocol first published: Issue 1, 1997

Review first published: Issue 3, 1997

\begin{tabular}{lll}
\hline Date & Event & Description \\
\hline 16 June 2008 & Amended & Converted to new review format. \\
\hline 1 July 1999 & New search has been performed & Search updated. One new trial identified - Mackrodt 1998. \\
\hline
\end{tabular}

\section{CONTRIBUTIONS OF AUTHORS}

The original review was carried out by Chris Kettle and commented on by Richard Johanson. All entered data were double checked for accuracy by Richard Johanson and Chris Kettle.

In the 2009 update, Chris Kettle and Therese Dowswell carried out data extraction, assessed risk of bias, conducted analyses and drafted the text. Khaled Ismail commented on drafts.

\section{DECLARATIONS OF INTEREST}

Christine Kettle (CK) was the recipient of a fellowship from the lolanthe Midwifery Research Trust 1996, which provided funding to enable her to carry out a randomised controlled trial of perineal repair following childbirth (Kettle 2002). The lolanthe Midwifery Research Trust and Ethicon Ltd, UK (manufacturers of suture material) provided funding for employment of a part-time data management clerk for that trial.

CK and Khaled MK Ismail run perineal repair workshops both nationally and internationally and have developed an episiotomy and seconddegree tear training model with Limbs \& Things, UK.

C Kettle was the lead investigator for one of the included studies (Kettle 2002) and was not involved in the assessment of the trial or the data extraction. 


\section{SOURCES OF SUPPORT}

\section{Internal sources}

- The University of Liverpool, UK.

\section{External sources}

- Keele University, UK.

- North Staffordshire Hospital Trust, UK.

- National Institute for Health Research, UK.

NIHR NHS Cochrane Collaboration Programme Grant Scheme award for NHS-prioritised centrally-managed, pregnancy and childbirth systematic reviews: $\mathrm{CPGSO2}$

\section{DIFFERENCES BETWEEN PROTOCOL AND REVIEW}

The background and methods sections have been updated.

\section{INDEX TERMS}

\section{Medical Subject Headings (MeSH)}

*Sutures; Absorbable Implants; Catgut; Delivery, Obstetric [ ${ }^{\star}$ adverse effects]; Episiotomy [adverse effects]; Perineum [*injuries] [surgery]; Polyglactin 910; Polyglycolic Acid; Randomized Controlled Trials as Topic

\section{MeSH check words}

Female; Humans; Pregnancy 